\title{
Shadow Union in Local Labor Markets and Capital Structure*
}

\author{
DuckKi Cho and Lyungmae Choi ${ }^{\dagger}$
}

August 2021

\begin{abstract}
This paper identifies an externality of a firm's unionization that affects the capital structure decisions of non-unionized firms within a local labor market. We find that a union victory leads non-unionized firms to increase market leverage ratios by 0.9 to 1.3 percentage points. This "shadow union" effect is more pronounced when the probability of unionization rises in a larger margin and firms face higher union rents conditional on being unionized. The threat is credible enough to shape corporate financing decisions: shadow unions raise the wages of employees and increase the likelihood of subsequent union victories in the relevant labor market.

Keywords: Shadow Union, Local Labor Market, Threat of Unionization, Capital Structure

JEL Classifications: J51, G32, J31, J42
\end{abstract}

${ }^{*}$ We are grateful to Nicolas Eugster (discussant), Hyunseob Kim, Jiyoon Lee (discussant), Katie Moon, Anna Neufeld (discussant), Jan-Oliver Strych (discussant), and participants to Boca Corporate Finance and Governance Conference, Conference on Asia-Pacific Financial Markets, International Conference of the French Finance Association, European Financial Management Association Annual Conference, Annual Conference of Accounting and Finance Association of Australia and New Zealand, and World Finance Conference for helpful comments and suggestions. Any errors are our own.

${ }^{\dagger}$ Cho, duckki.cho@phbs.pku.edu.cn, Peking University HSBC Business School;

Choi, lyungmae.choi@cityu.edu.hk, City University of Hong Kong 


\section{Introduction}

Labor unions became a pillar of the U.S. corporate system during the New Deal partly because of the pro-union stance of the Roosevelt administration. ${ }^{1}$ However, a continuing decline in the overall rate of union membership and coverage in the U.S. since 1970 has generated substantial interest and contention among politicians, the press, and the public. In fact, union membership density of private-sector workers in 1983 was more than twice what it was in 2017 (Figure 1). Similarly, the number of establishment-level union elections has dropped sharply since 2000, even though the percentage of successful elections slightly increased over this period (Figure 2). Does this imply that labor unions are becoming less important in the economy? Anecdotal evidence suggests that new union organizing in one firm also grabs the attention of workers and shareholders in non-unionized firms, which illustrates that unions can have a sizable impact on the economy through their influence on non-union firms. For example, the long-standing contentious relationship between Elon Musk, founder and CEO of Tesla, and the United Auto Workers (UAW) concerns not only the shareholders and workers of Tesla but also those of peer companies that have not yet been organized, such as Amazon and Google. ${ }^{2}$

In this study we investigate whether there are externalities of a firm's unionization that

\footnotetext{
${ }^{1}$ For example, the National Industrial Recovery Act of 1933, the National Labor Relations Act of 1935, and the split of the Congress of Industrial Organizations from the American Federation of Labor.

${ }^{2}$ A CNBC News report titled 'Why Elon Musk's latest legal bout with the United Auto Workers may have ripple effects across Silicon Valley' on Dec. 7, 2018, noted that "when it [unionization of Tesla workers] happens, the outcome could have a far-reaching, high-stakes ripple effect across Silicon Valley and beyond ... fellow tech companies could feel the effects ... employees at Amazon, Google and other non-auto tech giants could be emboldened to follow." retrieved from https://www.cnbc.com/2018/12/07/ teslas-bout-with-uaw-union-may-have-ripple-effects-in-silicon-valley.html
} 
affect the financing policies of non-union firms in the relevant labor market. We call this externality "shadow union" effect. Prior literature identifies two opposing forces that shape firms' financial choices in response to unionization of their own employees. On one hand, a firm has an incentive to use more debt financing strategically to reduce the funds that are negotiated with a potential union, thereby protecting its shareholder wealth against labor rents (Bronars and Deere, 1991; Perotti and Spier, 1993; Matsa, 2010): the union threat effect. On the other hand, a firm may use less debt financing to reserve financial flexibility because employing more rigid labor (e.g., arising from being unionized) would increase a firm's operating risk and crowd out its financial leverage (Simintzi, Vig and Volpin, 2015; Serfling, 2016): the financial flexibility effect. Which effect will dominate depends on whether firms ex ante react to the threat of unionization in order to increase their bargaining power or $e x$ post react to the actual formation of union to accommodate an increased need for financial flexibility (Schmalz, 2018). We are able to isolate union threat effect from financial flexibility effect by examining whether and how successful union organization in one firm gives other, non-unionized firms an ex ante incentive to use more debt financing to combat the heightened threat of unionization. ${ }^{3}$ The mixed or null results documented in the literature is partly because the shadow union induces firms to internalize their bargaining considerations into capital structure even before the actual union formation.

It is important to estimate the shadow union effect within a local labor market because

\footnotetext{
${ }^{3}$ Such an ex ante response of firms to the union threat can partly explain why some regression discontinuity studies (e.g., DiNardo and Lee, 2004; Qiu, 2017; Schmalz, 2018) find little impact of unionization on firms. Since firms actively and endogenously distort their behavior in advance in the face of union threat, regression discontinuity, that compares firms before and after unionization, capture only the part of the full impact that unions have on firm behavior (Taschereau-Dumouchel, forthcoming).
} 
it is difficult for non-unionized workers to credibly threaten their employers with walkouts, slowdowns, or quitting their jobs after observing successful unionization in other labor markets due to costly job switching across labor markets. We therefore estimate the effect of shadow unions within a geographically localized area, commuting zone, which is used as a proxy for local labor markets in the literature (e.g., Autor and Dorn, 2013). The evidence documented in the literature lends support to this identification strategy: labor markets are local in the sense that the attractiveness of job offers declines with distance from the applicant's location (Manning and Petrongolo, 2017); competition among employers (Benmelech, Bergman and Kim, 2018) is geographically localized; and migration between sub-national labor markets in the U.S. has declined significantly since the 1980s (Molloy, Smith and Wozniak, 2014). We also consider employees' industry-specific human capital by using an alternative definition of local labor markets, states by industry, since it adds to the cost of changing jobs across industries (Kambourov, 2009; Artuç, Chaudhuri and McLaren, 2010).

Using union elections in both public and private firms that are obtained from the National Labor Relations Board (NLRB) for the period 1977 to 2010, we find that firms, on average, increase their market leverage ratio by 0.9 to 1.3 percentage points, a $6.2 \%$ to $8.6 \%$ increase relative to the sample median, after another firm in the same local labor market successfully organizes union (or "union victory"). The identification strategy relies on the assumption of orthogonality between union victory in one firm and unobserved characteristics of other firms in the same local labor market that affect their financing decisions. Even though some factors that affect the union election outcome in a firm may correlate with the firm's own financing decisions, it is unlikely that such factors correlate with other firms' 
capital structure. We nonetheless include in our regression a rich set of fixed effects that capture time-varying, unobserved factors at the state and industry level although doing so removes substantial identifying variation. In addition, by including firm fixed effects, we also control for any fixed differences in leverage across firms in estimating the shadow union effect. ${ }^{4}$ Using financial leverage is not the only strategy a firm can implement to improve its bargaining position against labor union. By holding less liquid assets, a firm can make a credible threat to the union with the risk of liquidity shortage (Klasa, Maxwell and OrtizMolina, 2009). Consistent with the notion of heightened union threat, we find that firms hold less cash reserves after shadow union organizing, suggesting that firms' taking more aggressive financial policies in response to unionization of other firms in the same local labor market. We have further verified robustness of this shadow union effect to alternative definition of local labor markets, placebo tests in which we randomly assign a firm's local labor market, and alternative measures of financial leverage.

We propose that if one firm passes a union election, workers in other, non-unionized firms within the same local labor market can pose a more credible threat to organize a union. A heightened threat of unionization could provide firms with an incentive to increase the use of debt in their capital structure, as modeled in Bronars and Deere (1991). In this model, the threat of unionization is determined by both the probability of organizing a collective bargaining unit and the amount of union rents conditional on unionization. Hence, the threat

\footnotetext{
${ }^{4}$ We opt not to employ a regression discontinuity (RD) design which is often used in the literature that examines the effect of unionization of a firm on its own policies. A firm with vote share just below the $50 \%$ threshold is a good comparison to a firm just above the threshold, which enables RD designs to be "as good as a randomized experiment" at least locally (Lee and Lemieuxa, 2010). However, this does not necessarily hold for the peers of these firms.
} 
is greater when (i) firms experience a larger increase in the probability of being organized and/or (ii) they face higher union rents once union is organized. The marginal increase in the probability of unionization is larger when a firm's workforce consists of a large number of middle-to-low wage workers because unions are more likely to organize workers in the middle-to-bottom of the wage distribution (Bivens, Engdahl, Gould, Kroeger, McNicholas, Mishel, Mokhiber, Shierholz, von Wilpert and Wilson, 2017). Furthermore, a more salient union victory (i.e., multiple shadow unions) would increase the probability that non-union firms in the same local labor market will unionize by a larger margin. Consistent with these ideas, we find that shadow unions have a stronger impact on the leverage ratio of non-union firms when these firms have a larger fraction of middle-to-low wage workers and when shadow unions are formed multiple times in local labor markets.

We further explore variations in union rents to confirm the heightened threat of unionization. The larger the value of union rents (conditional on workers being organized), the greater such threats of unionization become. Motivated by the labor unions literature, we identify three factors that affect union rents: labor intensity, unemployment rates, and product market competition. First, the total amount of union rents apparently increases as the labor share of total output increases. Second, high unemployment in firms' geographic area weakens workers' relative bargaining strength, and hence union rents (Christofides and Oswald, 1992). Third, previous research on labor rent sharing shows that product market competition can alter rent sharing and union behavior (Rose, 1987; Abowd and Lemieux, 1993; Guadalupe, 2007). More specifically, when competition rises union power declines, which implies a decline in union rents. In a series of conditional analyses, we indeed find 
that a union victory in one firm has a greater impact on the leverage of other, non-unionized firms that have higher union rents, which is consistent with the heightened threat channel. ${ }^{5}$

To validate whether the threat of unionization is sufficiently large enough to play a role in shaping corporate financing decisions, we examine the effect of a shadow union on wages. Wages should reflect workers' enhanced bargaining power, much of which arises from credible threats. Following the formation of shadow unions, other non-union firms in the relevant labor market are more worried about workers being unionized, as a consequence, they are willing to set higher wages for workers (especially for those who may vote in favor of the union) to influence a union vote, thereby staving off unionization. Using aggregated wage data from the Quarterly Workforce Indicators, we find that, following a union victory, the average wages of employees in the relevant labor market increase by $0.9 \%$. This is consistent with union spillover effects on the wages of non-union workers documented in the literature (Rosen, 1969; Fortin, Lemieux and Lloyd, 2019; Taschereau-Dumouchel, forthcoming). Furthermore, we find that the heightened threat by shadow unions increases the likelihood of subsequent union victories in local labor markets. These results thus reinforce the union threat channel through which strategic incentives to use debt could spill over into non-union firms within a local labor market.

This article is related to several strands of the literature in both economics and finance.

${ }^{5}$ The literature on labor and financial leverage documents that a reduction in worker unemployment risk (Agrawal and Matsa, 2013) or enhancement of direct employee power via board representation (Lin, Schmid and Xuan, 2018) leads to increased leverage. We note that the shadow union effect documented in this paper results from the heightened threat of unionization not from the actual formation of unions, the latter of which may affect the unemployment risk or power of employees. Therefore, in the absence of formal labor market institutions, these alternative explanations are unlikely to drive our findings. 
Previous research (Bronars and Deere, 1991; Perotti and Spier, 1993; Matsa, 2010) identifies the use of debt financing as a credible bargaining tool of shareholders to protect their wealth against labor rents. Building on this literature, we identify a novel externality of union victory that has important implications for corporate financing decisions of non-union firms in the same local labor market. By isolating the union threat effect from the financial flexibility effect, we address a substantive question on the impact of union threat on corporate financing policies debated in the literature. Our study also complements the literature that documents the importance of product market as a determinant of capital structure decisions (e.g., Bradley, Jarrell and Kim, 1984; Brander and Lewis, 1986) by identifying local labor market as a new dimension of commonalities in capital structure. Whereas the identities of common variation in capital structure within product markets are largely unexplored (Frank and Goyal, 2008, 2009), ${ }^{6}$ we identify shadow union effect as an underlying mechanism of such commonalities in firm leverage ratios. Relatedly, our findings also have important implications on the comovement in regional business cycles (Giroud and Mueller, 2018) by uncovering a potential source of comovement in regional firm leverage growth. Broadly, this study also adds to the large literature on labor economics that has studied the ripple effects of institutional changes in labor markets. Whereas the related literature (Rosen, 1969; Lee, 1999; Fortin et al., 2019; Taschereau-Dumouchel, forthcoming) examines implications for wage or employment, we document that non-union firms are also distorting their financing policies in response to the threat, thereby highlighting a sizable impact of unions on the

\footnotetext{
${ }^{6} \mathrm{~A}$ few notable exceptions include the studies by MacKay and Phillips (2005) and Leary and Roberts (2014), both of which focus on the product markets. MacKay and Phillips (2005) uncover a firm's position within its product market as a source of intra-industry variation in capital structure. Leary and Roberts (2014) identify strong interdependencies in corporate financing policies among firms in the same product markets and attribute these findings to peer effects.
} 
economy. Last, we attempt to move beyond anecdotes and present large sample evidence that non-unionized workers can pose a credible threat of unionization to their employers after observing a successful union election in their local labor market. Such threat creates a strategic incentive for these employers to use less conservative financial policies.

The outline of the article is as follows. Section 2 describes the data sources, defines local labor markets, and presents descriptive statistics on union elections and the key variables. Section 3 details the identification strategy, discusses the shadow union effects on financial policies, and presents the results of various robustness tests. Section 4 evaluates potential mechanism through which union victory in one firm shapes corporate financing decisions of other, non-union firms within the same local labor market. Section 6 concludes.

\section{Data and Key Variables}

\subsection{Data and Sample Construction}

We combine multiple databases to study the effects of one firm's unionization on financing decisions of its peer firms in the same local labor market. This section describes data collection, sampling, and key variable construction methods.

\subsubsection{Union Election Data}

We first collect union election data from the National Labor Relations Board (NLRB) for the period 1977 to 2010. The NLRB provides detailed data on the results of union elections in the United States that are supervised by NLRB, including employer name and location (state 
and city), date of election, ballot type, number of eligible voters, and number of votes for and against unionization at the establishment level. ${ }^{7}$ For the earlier sample period (1977-1999), we download the combined data from Thomas Holmes's website, which are sourced from Henry Farber, Bruce Fallick, National Archives, and CHIPS files from NLRB, and used in Holmes (2006). ${ }^{8}$ More recent data (2000-2010) can be obtained either from the NLRB Case Activity Reports (Tally of Ballots) or by filing a Freedom of Information Act (FOIA) request. The records we use are readily available at FOIAonline (or FOIA E-Library) website. ${ }^{9}$

We eliminate elections for which outcomes are not available and those in which multiple labor organizations competed in order to mitigate the potential confounding effects of multiple candidates. Hence, we focus on elections in which only one labor organization is on the ballot. ${ }^{10}$ We also focus on elections of the type RC (Certification of Representative Petition) which refers to a petition filed by an employee or group of employees, or any individual or labor organization acting in their behalf, for an election to certify a representative for collective bargaining in an appropriate unit. Our focus on the RC petition ensures that the employees in the bargaining unit are newly organized. Following Lee and Mas (2012), we exclude elections in which the number of eligible voters is less than 100 . We also require union elections to have valid information on the location of employer's establishment in order to identify their corresponding local labor markets. Our final sample consists of 15,369 unique union elections in both public and private firms between 1977 and 2010. We note that our

\footnotetext{
${ }^{7}$ We note that a union election is held at an establishment level while the financial leverage (outcome variable) is measured at the firm level.

${ }^{8}$ http://users.econ.umn.edu/ holmes/data/geo_spill

${ }^{9}$ https://foiaonline.gov/foiaonline/action/public/home

${ }^{10}$ There is only a small fraction of elections that have multiple candidates. Our results are robust to including these elections.
} 
union election data have different industry classifications across years: three-digit SIC codes for the years 1977 to 1999 and three-digit NAICS codes for the years 2000 to 2010. Using the Census Bureau's concordance between NAICS and SIC, we map each three-digit NAICS code in the later sample period to a two-digit SIC code because our alternative definition of local labor markets utilizes two-digit SIC codes. ${ }^{11}$

\section{[Insert Figure 2 here.]}

Panel A of Figure 2 plots the number of union elections, average percentage votes in support of union, and percentage of successful elections by year. Percentage Votes in Support of Union is calculated as a ratio of the number of votes for a union to the number of eligible voters, or the sum of votes for unionization and against unionization, whichever is greater. We define successful elections as those with Percentage Votes in Support of Union being greater than or equal to 50\%. Panel B of Figure 2 shows the density of Percentage Votes in Support of Union over the entire sample period. Consistent with well-documented decline in the unionization movement in the United States (Farber, 1990; Açıkgöz and Kaymak, 2014), the number of establishment-level union elections also declined over the sample period, especially in the early 1980s and in 1999-2010 period. Farber and Western (2002) document a similar sharp decline in union organizing activity in the early 1980s using the NLRB-supervised representation elections held from 1940 to 1999. We note, however, that these sharp declines in the number of union elections were not accompanied by a parallel decline in either the percentage votes for union or the percentage of successful elections. For instance, conditional on having union elections, the share of votes in favor of unionization in fact increased, from

\footnotetext{
${ }^{11}$ If there are multiple matches for a given three-digit NAICS, we choose a two-digit SIC code that has the largest number of matched four-digit SIC codes.
} 
$40 \%$ to $43 \%$, and the percentage of successful elections rose from $24 \%$ to $34 \%$ over $1999-2010$.

It is important to note that, even though our sample consists of only public firms for which financial leverage is measurable, we are able to make use of all union elections by public and private firms reported by the NLRB, only with minimum selection criteria described in Section 2.1.1. This research design has several advantages over the existing studies that make limited use of union elections by focusing on those of public firms. First, it enables us to increase the number of events (i.e., shadow union organizing) examined in this study, which enhances the power of our tests. Importantly, we are able to identify more general implications of union threat effects for corporate financing decisions by examining the externality of both public and private firms' unionization.

\subsubsection{Quarterly Workforce Indicators}

We obtain data on the average wages of employees in the local labor markets from the U.S. Census Bureau's Quarterly Workforce Indicators (QWI). The main source data for the QWI are the Census Bureau's Longitudinal Employer-Household Dynamics (LEHD) linked employer-employee microdata, which are unique job-level data (not firm- or person-level data) and cover over $95 \%$ of U.S. private sector jobs. The QWI provide a rich set of local labor market statistics at the aggregate level by four-digit NAICS industry, employee demographics (age, gender, education, and race/ethnicity), employer age and size, and geography (state and county). ${ }^{12}$ The data are collected through a unique federal-state data sharing collaboration,

\footnotetext{
${ }^{12}$ The data are drawn from a wide range of sources, including administrative records on employment, Social Security data, federal tax records, and other census and survey sources: Unemployment Insurance Earnings Data (UI), Quarterly Census of Employment and Wages (QCEW), Business Dynamics Statistics (BDS), and demographic sources. Details on each data source can be found at http://lehd.ces.census.gov/data/.
} 
the Local Employment Dynamics (LED) partnership. The partner states submit quarterly data from administrative record systems, which are less subject to measurement errors caused by self-reporting than other survey-based data. Total wages reported by the Unemployment Insurance Earnings Data include gross wages and salaries, bonuses, stock options, tips and other gratuities, and the value of meals and lodging, where supplied. Hence, the earnings data from the QWI essentially capture the workers' total gains from their employment. The QWI are produced quarterly, and the earliest time series begin in 1990. Because the coverage of QWI data is limited before 1994, we use wage data from 1994 onward in our analysis.

\subsubsection{Union Coverage Data}

We obtain data on private sector labor union membership, collective bargaining coverage, and density estimates from the Current Population Survey (CPS) conducted by the Bureau of Labor Statistics (BLS). Hirsch and Macpherson (2003) compile the data using a similar method used by BLS to construct the collective bargaining coverage data by industry (beginning in 1983) and by state (beginning in 1977), which are available on the authors' website. ${ }^{13}$

We note that the industry-level union coverage data use different industry classifications across years: the 1980 Census Industry Code (CIC) for the years 1983-1991, the 1990 CIC for the years 1992-2002, the 2002 CIC for the years 2003-2008, and the 2007 CIC for the years 2009-present. Using the industry crosswalk files provided by David Dorn, we first match 1980 and 1990 CIC codes to SIC 4-digit codes. ${ }^{14}$ We match the 2002 and 2007 CIC

\footnotetext{
${ }^{13} \mathrm{http}$ ://www . unionstats. com/

${ }^{14}$ We thank David Dorn for making the crosswalk files available on his website (http://www. ddorn.net/ data.htm).
} 
codes to the 1990 CIC codes using the Census Bureau's concordance of different vintages of CIC codes. Then we convert these matched 1990 CIC codes into SIC 4-digit codes. If there are multiple CIC codes for a given SIC code, we calculate the employment-weighted average of union coverage rates. Finally, because one of the definitions of local labor markets relies on state and two-digit SIC codes (see Section 2.2), we construct SIC two-digit level union coverage rates by using the employment-weighted average of four-digit SIC codes that belong to each two-digit SIC.

[Insert Figure 1 here.]

Panel A of Figure 1 plots the total number of workers who are union members in thousands (blue bars) and the percentage of workers who are union members (red line). Panel B plots the total number of workers who are covered by a collective bargaining agreement in thousands (blue bars) and the percentage of workers covered by a collective bargaining agreement (red line). These figures are based on the private sector workers, and the sample period runs from 1983 to 2017. We observe a clear decline in the overall rate of union membership and coverage over the sample period. In fact, union membership (coverage) density has decreased from $16.5 \%(18.5 \%)$ in 1983 to $6.5 \%(7.3 \%)$ in 2017 . We note that workers who are not union members could be covered by a collective bargaining agreement.

\subsubsection{Sample Construction}

Our primary sample consists of all non-financial firm-year observations in the annual Compustat database between 1978 and 2015. ${ }^{15}$ We require that all firm-years have nonmiss-

\footnotetext{
${ }^{15}$ We chose this sample period because the union election data are available for the years between 1977 and 2010, and we estimate the effects of a shadow union over the five-year horizon (in our baseline specifications) following a successful union election in the local labor markets.
} 
ing data for the relevant variables used in our analysis (the list of these variables is discussed in Section 3.1). We measure financial leverage in four ways. As suggested by Welch (2011), we measure Book Leverage as the debt-to-capital ratio because the debt-to-assets ratio treats non-financial liabilities as equity. The debt-to-capital ratio is the total debt divided by the sum of total debt and book value of equity in which the total debt is the sum of long-term debt and debt in current liabilities. Alternatively, we measure book leverage, Alternative Book leverage, as the total debt divided by the book value of total assets, as is commonly used in the literature (e.g., Lemmon, Roberts and Zender, 2008). On the same grounds, we define Market leverage as the ratio of total debt to the sum of total debt and market value of equity. We also use Alternative Market leverage defined as the total debt divided by the market value of assets in which the market value of assets is the sum of market value of equity and book value of assets minus book value of equity. Following Lemmon et al. (2008), we also require both book and market leverage to lie in the closed unit interval, $[0,1]$. We winsorize all other potentially unbounded variables at the top and bottom one percent to mitigate the effect of outliers. The construction of all other variables used in this study is described in the appendix.

\subsection{Definition of Local Labor Markets}

We study how worker unionization in one firm affects the financing decisions of other, non-unionized firms in the same local labor market. It is crucial to estimate the effect of a shadow union within a localized geographic area because workers in non-unionized firms in another area cannot pose credible threat to their employers, in part because of the difficulty 
of moving from one area to another for a new job. The evidence documented in the literature lends support to this identification strategy. For instance, Manning and Petrongolo (2017) argue that labor markets are local in the sense that the attractiveness of job offers declines with distance from the applicant's location; Benmelech et al. (2018) provide evidence that competition among employers is geographically localized and local-level employer concentration is negatively associated with wages. Therefore, we define local labor markets by focusing on relatively localized geographic areas, commuting zones, as commonly used in the labor economics literature (e.g., Autor and Dorn, 2013). Switching jobs is costly if it requires commuting to a location outside of the employee's current commuting zone. Therefore, this definition suits the purpose of our study by using a relevant and more restrictive geographic condition of local labor markets than a broader classification, for example, states. The fact that migration between sub-national labor markets in the U.S. has declined significantly since the 1980s (Molloy et al., 2014) further supports our definition of local labor markets.

Commuting zones $(\mathrm{CZs})$ are clusters of U.S. counties that are characterized by strong within-cluster and weak between-cluster commuting ties, which are originally constructed by Tolbert and Sizer (1996). These commuting zones are based on the county to county flows of commuters that are analyzed with a hierarchical cluster algorithm. Hence, CZs are intended for the use of spatial measures of local labor markets, which are primarily based on economic geography rather than other factors such as minimum population. Our procedure to identify a CZ that is relevant to each union election is as follows: first, using the city where the union elections were held, we identify the corresponding county from a city-county mapping table; then we map each county to a $\mathrm{CZ}$ using the county-CZ crosswalk provided 
by David Dorn. ${ }^{16}$ Similarly, we map the CZ to each firm in our Compustat sample using the firm's headquarters location (city). ${ }^{17}$ In our baseline specifications, we estimate the impact of shadow union on corporate financing decisions in local labor markets that are defined at the commuting zone level.

Alternatively, we define local labor markets by considering industry-specific human capital, which is less portable across industries hence increases the cost of changing jobs (Kambourov, 2009; Artuç et al., 2010). However, we are not able to incorporate industry-specific human capital in our CZ-based local labor markets by further segregating each CZ into different industries. This is because the events in our study, i.e., successful union elections by other firms, are too sparse in these two-dimensional local labor markets (for instance, CZ $\times$ SIC two-digit $=741 \times 67=49,647)$ to reliably estimate the effect of a shadow union. Therefore, we use geographically more broader units, states, and further divide each state by industry to overcome such a drawback. We also examine an alternative definition of local labor markets using the economic areas, a set of U.S. counties, defined by the Bureau of Economic Analysis.

\subsection{Descriptive Statistics}

Table 1 provides descriptive statistics on the union elections used in the analyses. Panel A shows that the number of union elections is 15,369 , which includes elections held in establishments of both public and private firms. The mean (median) of percentage votes in favor

\footnotetext{
${ }^{16}$ We incorporate any changes of FIPS county codes in matching counties to CZs as outlined in http: //www.ddorn.net/data.htm

${ }^{17}$ We do not use COUNTY variable in Compustat because most of firm-year observations have missing values.
} 
of unionization is $38.6 \%(37.1 \%)$ and its standard deviation is $15.4 \%$. Since union election results are determined by a simple majority, we define Passage as an indicator variable that equals one if a firm is unionized as a result of a vote (i.e., Percentage Votes in Support of Union is greater than or equal to $50 \%$ ), and zero otherwise. On average, $22.0 \%$ of elections are passed over the entire sample period. In Panel B, we report the distribution of union election occurrence by industry (SIC division) and corresponding summary statistics of Percentage Votes in Support of Union and Passage. Union elections are dispersed across all industries: manufacturing has the largest number, followed by services and transportation, communications, electric, gas, and sanitary services. The public administration sector exhibits the highest average percentage of votes in favor of unionization (44.3\%); the finance, insurance, and real estate sectors the lowest (33.3\%). Public administration ranks first in the average percentage of successful votes (39.5\%). We note that, although we use union elections in the finance sector to identify shadow union, we exclude financial firms in our sample in investigating capital structure following Lemmon et al. (2008). In Panel C, we aggregate the election-level data at the commuting zone-level and report the cross-sectional distributions. Percentage Votes in Support of Union and Passage are the average values for each commuting zone with at least one election for the period 1977 to 2010. On average, each county holds 20.1 elections and 4.4 successful elections for the entire sample period.

\section{[Insert Table 1 here.]}

Table 2 reports summary statistics of our variables of interest for firm-year observations. Book (Market) Leverage has a mean of $28.7 \%(22.2 \%)$ and a median of $25.5 \%(14.7 \%)$, which indicates the distributions of these ratios are right-skewed. Alternative measures of 
leverage ratios have lower means and medians than the main measures due to their larger base in denominator. Shadow Union is our key variable, which is an indicator variable that equals one if another firm in the same local labor market passes union election over the previous five years, and zero otherwise. ${ }^{18}$ The mean of Shadow Union is $0.828(0.224)$ when we use commuting zones (state by industry) to identify local labor markets. Out of 156,250 firm-year observations, 37.6\% observations have within-firm variations, on which our identification relies, with a mean of 0.722 .

[Insert Table 2 here.]

Figure 3 visualizes the geographic coverage of shadow union in local labor markets for the entire sample period 1977 to 2010 in which we define local labor markets at the commuting zone-level. In this figure, commuting zones $(\mathrm{CZs})$ where at least one successful union election was held during the entire sample period are marked with blue color whereas those without any successful election are non-colored. We define successful elections as those with Percentage Votes in Support of Union being greater than or equal to 50\%. We note that, out of 741 CZs, $426 \mathrm{CZs}$ had at least one shadow union (blue colored CZs) over the sample period. To gauge the economic importance of shadow union, we use the 2010 County Business Patterns by U.S. Census and find that these $426 \mathrm{CZs}$ cover $94 \%$ and $93 \%$ of total employees and total number of establishments in $741 \mathrm{CZs}$, respectively. These observations indicate that even a small number of union elections can have a substantial impact in the economy given that a large number of firms in the same local labor markets are affected by the shadow union

\footnotetext{
${ }^{18}$ We code Shadow Union equal to one only when there is a union victory. That is, we do not assign the value of one if there is a lost election. Although the lost election may indicate union organizing effort or attempt, it reveals that such an attempt fails to succeed and that no workers would receive benefits that they could have gained if the election was successful. Therefore, we do not expect a spillover effect for the unsuccessful elections.
} 
effect we document in this article.

[Insert Figure 3 here.]

\section{The Effect of Shadow Union on Financing Decision}

\subsection{Baseline Results}

We estimate the effects of a firm's unionization on the capital structure of non-unionized firms in the same local labor market using the following generalized difference-in-differences approach. As outlined in Section 2.2, we define local labor markets at the commuting zone level following Autor and Dorn (2013):

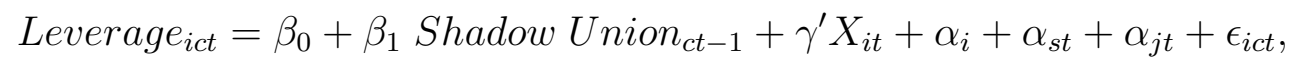

where $i$ indexes non-unionized firm, $c$ commuting zone, $s$ state, $j$ industry, and $t$ year; Leverage $_{i c t}$ is one of four measures of financial leverage as defined in Section $2.1 .4 ; X_{i t}$ is a vector of firm-level control variables, and $\alpha_{i}, \alpha_{s t}$, and $\alpha_{j t}$ indicate a vector of firm, stateby-year, and industry-by-year fixed effects, respectively. Shadow Union $_{c t-1}$ is an indicator variable that equals one if another firm (not firm $i$ ) in the same local labor market passes union election over the previous five years (from $t-5$ to $t-1$ ), and zero otherwise. We opt to use a five-year horizon to estimate the shadow union effect on capital structure because leverage appears to be persistent and sticky (e.g., Lemmon et al., 2008; Gomes, Jermann and Schmid, 2016). We check robustness of our results to using alternative horizons in Section 3.3. Firms may ex ante use more debt financing to increase their bargaining power in re- 
sponse to the threat of unionization (union threat effect) or ex post use less debt financing to accommodate an increased need for financial flexibility in response to the actual formation of union (financial flexibility effect). Although the union threat effect can be relevant ex post in every bargaining round for unionized firms, it is only relevant ex ante for non-unionized firms that are of our main interest. The financial flexibility effect is much more salient when the union is actually formed even though the effect can also take place ex ante to some extent. Since our identification strategy allows us to isolate union threat effect from financial flexibility effect by focusing on non-unionized firms, we expect $\beta_{1}$ to be positive.

In identifying non-unionized firms in a local labor market in year $t$, we assume that firms are not unionized yet if they never had a successful union election before year $t$ based on the NLRB data. We note that it is not impossible for workers to organize unions and to win recognition from employers outside of the National Labor Relations Act, in which case the election does not show up in the NLRB data. Workers can do so using direct actions such as boycotts, raising attention of communities, etc. Workers in non-unionized firms may initiate union organizing activity once they observe a successful election in the local labor market, and may eventually manage to do it. ${ }^{19}$ Therefore, once a firm (firm $i$ ) recognizes a union in year $t$, subsequent year observations thereafter (all years after year $t$ ) are removed in our sample because our goal is estimating the externalities of unionization. It is important to note that the shadow union induces a firm to internalize its bargaining considerations into capital structure decision before the actual formation of union. In other words, the shadow union gives the firm a strategic incentive to increase its debt even there is no actual union

\footnotetext{
${ }^{19}$ See Holmes (2006) for the geographic spillover of unionization.
} 
being organized (i.e., the union threat effect). ${ }^{20}$ All standard errors are clustered at the firm level. We also cluster standard errors at the local labor market level and obtain similar results. $^{21}$

The identification assumption central to the causal interpretation of these estimates requires orthogonality between a vote to unionize by one firm and unobserved characteristics of other firms in the same local labor market that affect the financing decisions of these firms. Therefore, following Rajan and Zingales (1995), we control in Equation (1) for a rich set of observed, time-varying characteristics, including the proportion of fixed assets, Tangibility, as a proxy for potential collateral); market-to-book ratio, Market-to-Book, as a proxy for investment opportunities; log of sales, $\ln$ (Sales); modified Altman's Z-score, Modified Z-Score, following Campello, Graham and Harvey (2010); and return on assets, Return on Assets. Even though some factors that affect the outcome of a vote on unionization in one firm may correlate with its own financing decisions, it is unlikely that such factors correlate with other firms' capital structure. We nevertheless include in our regression state-by-year and industry-by-year fixed effects to capture time-varying unobservable factors that might affect firms in the same labor market in a similar way: those factors may affect both the likelihood of firms being unionized and their financing decisions. For example, workers would be more likely to hold an election to organize a union when they expect higher future surplus so that they can extract a larger amount of rents. Since a productivity shock could be local

\footnotetext{
${ }^{20}$ We do not remove entire year observations of a firm once it passes union election during the sample period. Therefore, our estimation is not subject to a potential look-ahead bias. We obtain similar results when we include all such observations.

${ }^{21}$ Throughout the paper, we conservatively report standard errors clustered at the firm level because, in most specifications, firm-level clustering yields higher standard errors than local labor market level clustering.
} 
or industry-wide, other firms in the same local area would also experience higher surplus in future years, which enhances their debt capacity and induces them to use more debt. Given that we include a rich set of fixed effects, such an alternative explanation does not appear to play a leading role. Although adding these fixed effects would remove substantial identifying variation, we are able to control the vast majority of such time-varying, unobserved factors. Finally, by including firm fixed effects, we also control for any fixed differences in leverage across firms; hence we exploit within-firm variation of Shadow Union to identify the relation between leverage and unionization of other firms in the same local labor market.

Although a regression discontinuity (RD) design is often used in the literature that examines the effect of unionization of a firm on its own policies, we opt not to employ such a methodology in our study. In previous studies that use RD design, a firm (say, firm A) with vote share just below the $50 \%$ threshold is indeed a good comparison to a firm (say, firm B) just above the threshold, hence RD designs are "as good as a randomized experiment" at least locally (Lee and Lemieuxa, 2010). However, this does not necessarily apply to the peers of firms $\mathrm{A}$ and $\mathrm{B}$ in the local labor market, and hence, it does not make each group of peer firms "randomized". Moreover, RD estimates are only valid for the observations close to a certain threshold, which is a crucial challenge to this methodology. Our empirical design is not subject to such a concern regarding external validity, yet has a relatively clean identification by examining externalities of union victory.

[Insert Panel A of Table 3 here.]

Panel A of Table 3 shows estimation results of Equation (1) in which we define local labor 
markets over commuting zones. Columns (1) to (3) report the results using Book Leverage as the measure of leverage, while columns (4) to (6) report the results using Market Leverage. To control for time-varying industry-wide shocks that coincide with successful votes to unionize in other firms, we include industry-by-year fixed effects in columns (1) and (4). The coefficients on Shadow Union show that the book and market leverage ratios of firms in the local labor market, on average, increase by 0.9 percentage points, after another firm in the same local labor market successfully passes union election. These coefficients are statistically significant at the $1 \%$ level, and the relative increases in book leverage ratios and market leverage ratios amount to $3.5 \%(=0.899 / 25.521)$ and $6.2 \%(=0.910 / 14.657)$ of the median leverage ratios, respectively. In columns (2) and (5), we include state-by-year fixed effects to control for time-varying state-wide shocks. The coefficient estimates are statistically significant at the $1 \%$ level and larger than those in columns (1) and (4): the relative increases in book leverage ratios (market leverage ratios) are $4.2 \%(8.6 \%)$ of the medians. Finally, in columns (3) and (6), we include both industry-by-year and state-by-year fixed effects and obtain similar robust results with the relative increases in book leverage ratios (market leverage ratios) being $4.6 \%(8.5 \%)$ of the sample medians. We note that all specifications include firm fixed effects. These results indicate that the effect of a shadow union on leverage is unlikely to be driven by time-invariant firm-specific factors or by time-varying industry-wide or state-wide shocks.

To examine whether the shadow union effects are economically meaningful, we compare the economic significance of our findings with that of the effect of tax changes on leverage documented in the literature. For example, Heider and Ljungqvist (2015) document that, 
following an increase in U.S. state corporate income taxes, firms increase their leverage by 1.04 percentage points on average. They also find that firms increase leverage by 0.41 percentage points for every percentage-point increase in a firm's weighted tax rate. The shadow union effects on leverage, which range from 0.90 to 1.26 percentage points reported in Panel A of Table 3, are comparable to the tax sensitivity of corporate debt policy documented in the literature. In addition, we compare the economic significance of other determinants of leverage and that of shadow union effects within our regressions. For example, a withinfirm one-standard-deviation change in tangibility, modified z-score, and return on assets is associated with a change in market leverage ratio of $1.75,1.02$, and 1.48 percentage points in absolute value, respectively. These calculations are based on the coefficients estimates in column (6), Panel A of Table 3. The details of these calculations are reported in Table IA.1 of the Internet Appendix. These comparisons suggest that the shadow union effect on leverage is economically significant and comparable to those of other traditional determinants of financial leverage.

Figure 4 presents a graphical overview of the shadow union effect. It plots the withinfirm variation in the market leverage ratios, net of changes in aggregate macroeconomic conditions (i.e., net of cross-sectional average for each year), for the treated firms (red solid line) and control firms (blue dotted line). We define treated firms as those located in a local labor market where another firm successfully votes to unionize in year $t$ and control firms as those located in other local labor markets where none of the firms pass union election during the five years before and after year $t$. We do not include any firms with multiple shadow union events from year $t-5$ to $t+5$ in the treated group. The $y$-axis represents the 
within-firm variation in the market leverage in Panel $\mathrm{A}$. The $\mathrm{x}$-axis indicates years relative to successful union elections by other firms in the same local labor market of the treated firms. In Panel B, we center the graphs of treated and control firms to their respective mean leverage ratios during the pre-event period (from year $t-5$ to $t-1$ ). These figures clearly show that although there is no apparent differences of pre-trend in leverage between treated and control firms (i.e., parallel trend), the average market leverage of treated firms sharply increases after another firm in the same local labor market successfully votes to unionize. In contrast, there is no such increase observed in the control firms.

[Insert Figure 4 here.]

We note that several states in the U.S. have passed the right-to-work (RTW) legislation over our sample period (1978-2015): Texas (1993; revised), Idaho (1985), Oklahoma (2001), Indiana (2012), Michigan (2012), and Wisconsin (2015). The passage of these laws may weaken union bargaining power, which leads firms under these laws to lower their leverage ratio (Matsa, 2010). In addition, the passage of the RTW legislation may affect the probability of union victory in those states. To avoid such a complication, we exclude those states that have passed a RTW law and obtain similar results. The results are reported in Table IA.2 of the Internet Appendix.

[Insert Panel B of Table 3 here.]

In Panel B, we use an alternative definition of local labor markets, defined over state by industry (SIC two-digit), as discussed in Section 2.2. We include the same set of control variables and fixed effects as in Panel A. In all specifications, the coefficients are statistically significant either at the $1 \%$ or $5 \%$ level. For instance, the coefficient on Shadow Union in 
column (6) equals 0.7 percentage points, which is a $4.8 \%$ increase relative to the sample median of market leverage. The evidence is consistent with what we observe in Panel A of Table 3 and Figure 4: firms increase their leverage ratios after another firm in the same state and industry successfully votes to unionize. This alternative definition of local labor markets is much finer than that of CZ-based local labor markets in a sense that the former has 3,417 local markets (states including Washington D.C. $\times$ SIC two-digit $=51 \times 67=$ 3,417) whereas the latter has 741 local markets. The alternative definition based on states is geographically broader but restrictive to the same industry. The comparisons of results in Panels A and B indicate that the shadow union effects are geographically concentrated (within commuting zone) but not necessarily limited to within industry. We note that, as discussed in Section 2.2, we are not able to further segregate each CZ by industry because the local labor markets become too fine to estimate the effect of a shadow union. Alternatively, we define local labor markets based on the 179 BEA (Bureau of Economic Analysis) economic areas by 67 industries (two-digit SIC) and re-estimate Equation (1). The BEA economic areas, a set of U.S. counties, are based on commuting data from the 2000 decennial population census and newspaper circulation data from the Audit Bureau of Circulations for 2001 (see Johnson and Kort (2004) for detailed information on the construction of economic areas). We obtain similar results although not all of these estimates are precisely measured because union victory events are too sparse in these two-dimensional local labor markets. These results are reported in Panel A of Table IA.3 in the Internet Appendix.

We acknowledge that it has limitations to use the information about a firm's headquarters from the Compustat database in identifying the firm's relevant labor market: first, Compus- 
tat contains only the most recent location, not previous locations; second, a firm's operation may be geographically dispersed, hence its headquarters location does not necessarily reflect a place in which most of its workforce is. To address these concerns, we count the number of times each 10-K mentions a U.S. state name and use the relative state counts for each state as a proxy for a firm's operational intensity of each state (García and Norli, 2012). ${ }^{22}$ We restrict firm-year observations to have a state with the operational intensity greater than $50 \%$ and use that state and industry to identify a firm's local labor market. We reestimate the shadow union effect on market leverage with the refined sample: the estimated coefficients range from 1.032 to 1.492 and all are statistically significant despite a smaller sample size. These estimates are larger than those in columns (4-6) in Panel B of Table 3, which indicates that the measurement errors in identifying local labor markets are likely to bias our estimates toward zero.

\subsection{Alternative Strategic Action: The Effect of Shadow Union on Cash Holdings}

Using financial leverage is not the only strategy a firm can implement to improve its bargaining position with labor union. By holding less liquid assets in the presence of a union, a firm can make a credible threat to the union with the risk of liquidity shortage, which allows managers to gain concessions from the union (Klasa et al., 2009). If the shadow union is at work, firms also have an incentive to hold smaller cash reserves once another firm in the same local labor market passes union election. To verify this alternative strategy

\footnotetext{
${ }^{22}$ We thank Diego García for making the data on geographic dispersion of U.S. firms (1994-2008) available on his website (http://leeds-faculty.colorado.edu/garcia/data.html).
} 
and provide further supporting evidence of the shadow union effect, we examine the effect of a shadow union on firms' cash holdings. Cash holdings, Cash Holdings, are measured as the ratio of cash and short-term investments to total assets in percentage. Following Bates, Kahle and Stulz (2009), we include a set of determinants of cash holdings, including Cash Flow, Net Working Capital, Capital Expenditure, Leverage, Acquisitions, Market-to-Book, ln(Assets), Ind. CF Volatility, RED Expenditures, and Dividend Dummy.

[Insert Table 4 here.]

Table 4 provides the results of regressions of firms' cash holdings on the shadow union indicator and control variables. The majority of the coefficients on the control variables are statistically significant with the expected signs (Bates et al., 2009). In columns (1) to (3), we use our main definition of local labor markets at the commuting zone level whereas in columns (4) to (6), we use state and industry to identify local labor markets. All the estimated coefficients are negative and significant at the $1 \%$ level. In column (3) in which we include firm, industry-by-year, and state-by-year fixed effects, the coefficient on Shadow Union is -0.739. This estimate implies that firms decrease their cash holdings by 0.74 percentage points, a $9.6 \%$ decrease relative to the median, after another firm in the same local labor market passes union election. This is consistent with the idea that firms strategically hold less cash reserves to obtain bargaining advantages over union, which further supports the union threat effect in local labor markets that is documented in Section 3.1. 


\subsection{Robustness Tests}

This section checks the validity of our identifying assumption by randomly choosing a firm's local labor market and confirms robustness of the baseline results using other complementary empirical methods and alternative measures.

\subsubsection{Placebo Tests}

We perform a placebo test to check whether a false shadow union (i.e., false union victory in local labor markets) affects corporate financing policy. To construct these false union victories, we randomly choose a firm's local labor market (a commuting zone where its headquarters is located) by maintaining a cross-sectional distribution of firms in local labor markets as well as a panel structure of votes to unionize. Then we repeat the estimation of Equation (1) using a pseudo shadow union variable:

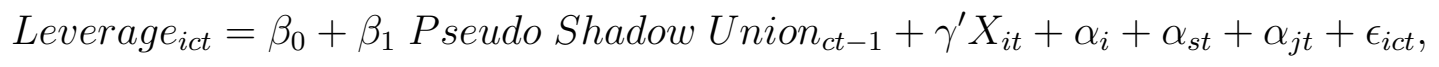

where Pseudo Shadow Union $_{c t-1}$ is an indicator variable that equals one if another firm in the same pseudo local labor market passes union election over the previous five years (from $t-5$ to $t-1$ ), and zero otherwise. We repeat this exercise 1,000 times and store the coefficients on Pseudo Shadow Union to gauge the likelihood of obtaining a significant coefficient, absent a true shock to firms' local labor markets.

[Insert Panel A of Table 5 here.]

[Insert Figure 5 here.] 
Panel A of Table 5 reports the empirical distribution of coefficients on Pseudo Shadow Union based on the bootstrapped sample. The mean and median of the distribution are close to zero for both book and market leverage, which indicates that a false union victory in one firm does not affect financial leverage of other, non-unionized firms in the same local labor market. Furthermore, the estimates in columns (3) and (6) of Panel A in Table 3 (1.162 and 1.249 , respectively) fall above the top $1 \%$ thresholds ( 0.759 and 0.572 , respectively), which is consistent with the corresponding p-values. In Figure 5, we plot the empirical distributions of these coefficients on Pseudo Shadow Union for book and market leverage ratios in Panels A and B, respectively. The green lines show kernel densities and the vertical red lines indicate the actual estimates in columns (3) and (6) of Panel A in Table 3. We conclude that the positive effect of a shadow union on leverage cannot be obtained randomly.

\subsubsection{Additional Robustness Tests}

This section further examines the robustness of the baseline results using complementary empirical approaches and alternative measures. First, we investigate shorter and longer horizons for the effect of a shadow union. To this end, we reconstruct Shadow Union ${ }^{3 Y R(7 Y R)}$ as an indicator variable that equals one if another firm in the same local labor market passes union election over the previous three (seven) years, and zero otherwise. Panels B1 and B2 of Table 5 present the results. All the coefficients remain statistically significant at the $1 \%$ level. Those for the three year horizon are smaller than our baseline results whereas those for the seven year horizon are larger than the baseline results. For example, the market leverage ratios of firms in a local labor market, on average, increase by 0.6 to 0.8 (1.1 to 1.4) percentage points, after another firm in the same local labor market successfully passes union 
election over the past three (seven) years. This confirms the visual inspection in Figure 4 that the effect of shadow union goes beyond three years .

[Insert Panels B1, B2, and C of Table 5 here.]

Second, we repeat the analysis using various alternative measures of financial leverage. In Panel C of Table 5, we use Alternative Book Leverage, defined as the total debt divided by the book value of total assets and Alternative Market Leverage, defined as the total debt divided by the market value of assets. All columns show qualitatively similar results to our baseline results.

Third, Shadow Union exhibits two types of within-firm variations: one is a switch from zero to one (i.e., emergence of shadow union) and the other is a switch from one to zero (i.e., disappearance of shadow union). Out of firm-year observations that change the value of Shadow Union, $69 \%$ switches from the value of zero to one, which captures a union victory in a commuting zone that previously did not have union victories. In addition, exploiting only the first type of variation, we reestimate columns (3) and (6) in Panel A of Table 3. The estimated coefficients are 1.767 and 2.107, respectively, and both of them are statistically significant at the $1 \%$ level. These results indicate that our results are not driven by disappearance of shadow union.

Finally, we cluster standard errors by industry, by state, or by local labor market, and obtain similar results for all specifications in Table 3 (not reported). It is possible that the control variables used in the regressions are also affected by the formation of shadow 
union. To avoid potential concerns regarding bad and/or endogenous controls, we estimate the shadow union effect without controls (reported in Panel B of Table IA.3 in the Internet Appendix) and with one-year lagged controls (in Panel C of Table IA.3). We confirm that our results are robust to these alternative specifications.

\section{Heightened Threat of New Unionization in Local La-}

\section{bor Markets}

Previous research identifies the use of debt financing as a credible bargaining chip of shareholders to protect their wealth against labor rents (Bronars and Deere, 1991; Perotti and Spier, 1993; Matsa, 2010). In particular, one key implication of the model developed by Bronars and Deere (1993) is that a firm increases its debt as the threat of unionization increases. In this model, the threat of unionization is determined by both the probability of organizing a collective bargaining unit and the amount of union rents conditional on unionization. If one firm passes a union election, workers in other, non-unionized firms in the same local labor market can pose a more credible threat to organize a union when (i) those firms face a larger increase in the probability of unionization or (ii) they are exposed to higher union rents. In this section, we provide evidence for the heightened threat channel through which a shadow union shapes corporate capital structure decisions in local labor markets. To this end, we examine the differential effects of a shadow union between firms with different levels of (i) marginal increase in the unionization probability and (ii) of union rents. 
A set of results reported in this section also serves to differentiate our main hypothesis from an alternative explanation that is based on the peer effects (Leary and Roberts, 2014). Specifically, non-union firms may simply mimic the capital structure of a newly unionized firm in the same local labor market. However, the maintained assumption in this alternative hypothesis is that the newly unionized firm increases its leverage after the passage of union election; the union threat effect dominates the financial flexibility effect. Given the mixed or null results on the effect of unionization of a firm on its own capital structure (partly due to the coexistence of two conflicting forces), this alternative explanation loses its firm ground. Furthermore, Leary and Roberts (2014) document suggestive evidence for learning and reputational concerns as potential motives for the peer effects in product markets. While these peer effects might be consistent with the observed commonalities in leverage ratios of firms in the same local labor market, it cannot account for the heightened threat in local labor markets unless we (unrealistically) assume that mimicking behavior is concentrated among firms that are more labor intensive, located in geographic area with lower unemployment rates, and face low product market competition. Thus the results in this section render this alternative interpretation unlikely.

\subsection{Marginal Increase in the Probability of Unionization}

An increase in the number of unionized jobs in a local labor market would lead more non-union workers in the same labor market to see the benefits of unions - e.g., higher wages; better benefits, including opportunities for leaves of absence; and a more democratic workplace (Yates, 2009) — thereby increasing the probability of unionization, especially for 
middle-to-low wage workers. In this section, we examine two factors that affect the magnitude of marginal changes in the probability of unionization: the wage distribution of workers and the salience of union victory. ${ }^{23}$

\subsubsection{Workers in the Middle or Bottom of the Wage Distribution}

The marginal increase in the threat of unionization, which is triggered by the unionization of another firm, may be small if a firm's workforce consists of a large number of high-wage workers. This is because middle-to-low wage workers are more likely to organize union than high-wage workers (Bivens et al., 2017). Since collective bargaining compresses the distribution of wages, high-wage workers tend to vote against the formation of union whereas middle-to-low wage workers tend to vote for it. The union wage effects documented in the literature (e.g., Card, 1996) support this notion: unions have a relatively larger impact on the wages of workers in the middle-to-bottom of the distribution, but little impact on those in the top of the distribution. Therefore, the shadow union effect on leverage ratios would be smaller when non-union firms have a larger fraction of high-wage workers. In this section, we investigate the relation between the shadow union effect on leverage and the wage distribution of workers.

To test the above prediction, we use industry-level annual median wage data from the Occupational Employment Statistics (OES) Survey by the Bureau of Labor Statistics. The

\footnotetext{
${ }^{23}$ Another factor that may affect the probability of unionization is industry- or geographic-level unionization rate. On one hand, the marginal increase in the probability would be larger when shadow unions are formed in highly unionized industries in which shadow unions are a realistic threat. On the other hand, the marginal increase would be smaller in highly unionized industries because firms in these industries have already been exposed to shadow union effects. Therefore, a priori predictions are not clear. In fact, we find no differential effects across unionization rates.
} 
data use SIC three-digit industry classification for 1997-2001 and NAICS four-digit classification for 2002 to present. Since the OES data before 1997 do not contain wage estimates, we take the time-series average of annual median wages to cover the entire sample period. Specifically, we define High (Low) Median Wage as an indicator variable that equals one if the time-series average of industry-level annual median wages is above (below) the median of the distribution, zero otherwise. ${ }^{24}$ Then we re-estimate Equation (1) by conditioning Shadow Union on these group indicators.

[Insert Table 6 here.]

Column (1) of Table 6 shows that the effect of a shadow union on book leverage is significant only when firms are more likely to rely on middle-to-low wage workers: the coefficient on Shadow Union, 1.545, is statistically significant at the $1 \%$ level and it is $33 \%$ larger than the unconditional estimate (1.162). Similarly, in column (2), the effect on market leverage is more pronounced for firms with a larger fraction of middle-to-low wage workers: both coefficients on Shadow Union are statistically significant (at the $10 \%$ and $1 \%$ level, respectively) but the coefficient for the low median wage group (1.569) is larger than that for the high median wage group (0.615). One-tailed tests also confirm that these two sets of coefficients are significantly different from each other with corresponding p-values are less than $3 \%$. These results are consistent with the idea of heightened threat of unionization that the marginal increase in probability of unionization (after a union victory of other firms in the same local labor market) will be larger if workers' wages are more likely to be at the lower middle of the wage distribution.

\footnotetext{
${ }^{24}$ The main effect of High Median Wage is absorbed by the firm fixed effects in the regressions.
} 


\subsubsection{Salience of Union Victory: Multiple Shadow Union Organizing}

The passage of a union election in one firm makes other firms in the same local labor market more likely to organize union, and even more so if multiple shadow unions were organized in the local labor market in the past. This is because, if a large number of workers benefit from newly organized unions, non-union workers in the same local labor market would more readily observe the benefits, for instance, through more frequent media coverage of the union victory or higher chance of having social connections with workers in unionized firms. The more salient the union victory is, the greater the increase in probability of unionization in local labor markets is. To measure the salience of each union victory, we construct Shadow Union ${ }^{\text {Multi (Single) }}$, an indicator variable that equals one if other firms in the same local labor market pass multiple (single) union elections during the previous five years, and zero otherwise. Using these new measures that capture the salience of shadow union organizing in the local labor markets, we re-estimate our baseline specification.

Columns (3) and (4) of Table 6 report the results. The results in column (3) shows that the coefficient on Shadow Union ${ }^{\text {Multi }}$ is statistically significant at the $1 \%$ level, while the coefficient on Shadow Union ${ }^{\text {Single }}$ is significant at the $5 \%$ level. More importantly, the coefficient on Shadow Union ${ }^{\text {Multi }}$ is larger by $58 \%$ than that on Shadow Union ${ }^{\text {Single; the }}$ former is also statistically greater than the latter with p-value of $6.8 \%$. We can draw a similar inference from Column (2) for the market leverage ratio. This finding supports the view that the impact of a shadow union triggered by multiple events over the past five years is greater than that triggered by a single union victory. These results are reassuring the 
earlier evidence provided in columns (1) and (2) of Table 6 by suggesting that a shadow union increases the probability that non-union firms in the same local labor market will unionize by a larger margin if it is more salient, i.e., formed multiple times.

\subsection{Conditional Analyses on Union Rents}

In the previous section, we provide evidence for the heightened threat of unionization in local labor markets by examining variations in the marginal increase in probability of being organized. To further confirm this channel, in this section, we examine another determinant of the threat: the amount of rents that union can extract conditional on workers being organized. The larger the value of union rents, the greater the threat of unionization. Therefore, if the shadow union effects we find are driven by this channel, one firm's vote to unionize would have a greater impact on leverage of other, non-unionized firms that have higher union rents. In the following sections, we investigate three factors that affect union rents: labor intensity, unemployment rates, and product market competition.

\subsubsection{Labor Intensity}

The total amount of union rents depends on the labor share. Therefore, the shadow union effect would be more pronounced for firms with a larger share of labor. To test this conjecture, we measure industry-level (SIC three-digit) labor intensity as follows: we first calculate firm-level labor intensity as the ratio of total staff expense to sales (Gorodnichenko and Weber, 2016); then we get the cross-sectional average of these ratios for each industryyear observation; finally, we obtain ten year moving average of labor intensity over the past 
10 years for each industry. ${ }^{25}$ Using this measure, we define High (Low) Labor Intensity as an indicator variable that equals one if a firm operates in the industries with above median (below median) labor intensity, and zero otherwise. We then estimate the shadow union effects by conditioning Shadow Union on the labor intensity indicator.

\section{[Insert Table 7 here.]}

Columns (1) and (2) of Table 7 show that the shadow union effect on leverage is more pronounced for firms operating in labor-intensive industries: for these labor-intensive firms, the shadow union leads to an increase in book (market) leverage of 1.8 (1.5) percentage points, a $7.1 \%(9.5 \%)$ increase relative to the sample median. These effects are significantly larger than the baseline unconditional effects. For example, in the book leverage regression (column (1)), the estimated coefficient, 1.832, is greater by $58 \%$ than that in column (1) in Panel A of Table 3. Compared to the coefficient estimates for firms with low labor intensity, those for labor-intensive firms are much larger: shadow union effect leads a 113 basis point greater increase in book leverage for labor-intensive firms. Furthermore, the differences in coefficients are statistically significant for book leverage with p-values of $1.4 \%$, while it is not significant for market leverage. Overall, the results are consistent with the hypothesis that the threat of unionization following successful union elections in local labor markets is relatively more severe for labor-intensive firms in which the total value of union rents is likely to be larger.

\footnotetext{
${ }^{25}$ This procedure ensures not only that the labor intensity measure is reliable but also that we can preserve the sample size in our analysis because only about $10 \%$ of firm-year observations have valid information on total staff expense in Compustat.
} 


\subsubsection{Unemployment Rates}

High unemployment in firms' geographic area weakens workers' relative bargaining strength, and hence union rents (Christofides and Oswald, 1992). Accordingly, we examine whether the shadow union effect is more pronounced for firms that is located in states with lower unemployment rates. ${ }^{26}$ We obtain state-level unemployment rates from the $\mathrm{Bu}-$ reau of Labor Statistics and construct an indicator variable, High (Low) Unemployment, that equals one if the unemployment rate of the state in which a firm's headquarters is located is above (below) the median of the entire distribution for a given year, and zero otherwise. We then estimate the shadow union effects by conditioning Shadow Union in our baseline specifications on the unemployment rate indicators. ${ }^{27}$

The results are presented in columns (3) and (4) of Table 7. For firms headquartered in states with lower unemployment rates, the coefficients on Shadow Union are statistically significant at the $1 \%$ level, but are insignificant or significant only at the $10 \%$ level for firms located in high unemployment states. The estimates indicate that shadow union effect leads firms headquartered in states with lower unemployment rates to increase their market leverage ratios by 1.4 percentage points, a $8.9 \%$ increase relative to the sample median. This effect is a 66 basis point greater increase in leverage compared to that for firms located in states with higher unemployment rates in which workers have relatively weaker bargaining power. This difference is statistically significant with a p-value of $5.8 \%$. Thus, consistent

\footnotetext{
${ }^{26}$ County-level unemployment rate data by the BLS, with which we can construct CZ-level unemployment rates, are available from 1990. We obtain a similar inference using CZ-level unemployment rates, however, the statistical significance of coefficients become weaker due to the limited sample size.

${ }^{27}$ High Unemployment is absorbed by state-by-year fixed effects in the regressions.
} 
with the idea that high unemployment rates weaken workers' bargaining power, the shadow union effect on leverage is more concentrated for firms headquartered in states with lower unemployment rates.

\subsubsection{Product Market Competition}

Previous research on labor rent sharing shows that product market competition can alter rent sharing and union behavior (Rose, 1987; Abowd and Lemieux, 1993; Guadalupe, 2007). More specifically, intense product market competition leads to a decrease in union power, which implies a fall in rents. For example, Rose (1987) finds that union wages declined substantially after the regulatory reforms of the late 1970s and early 1980s in the U.S. trucking industry which lower regulatory rents by facilitating entry of new firms and increasing price competition. Based on this literature, we hypothesize that the shadow union effect would be more pronounced in firms facing less product market competition because workers could exert more bargaining power.

To measure product market competition, we use the industry-level Herfindahl-Hirschman index. The literature on product market competition documents the limitations of using industry concentration measures that are constructed from Compustat data, which covers only the public firms in an industry (Ali, Klasa and Yeung, 2009). Therefore, we use HerfindahlHirschman index for the 50 largest companies (HHI50) collected from the Census of Manufacturers publications by the U.S. Census Bureau, which are based on all public and private firms in manufacturing industries. Although our sample shrinks to the manufacturing firms, we can avoid using a biased industry concentration measure solely based on the public firms. 
The Census data are based on four-digit SIC industries for the years 1982 to 1992 and sixdigit NAICS industries for the years 1997 to 2012. Since the Census of Manufacturers is published only in every five years, we apply the Census data for a given year to the two years immediately before and after it, following Ali et al. (2009). We then classify firms operating in the industries with above-median (below-median) HHI50 as those facing low (high) product market competition for each year.

We repeat the tests in Panel A of Table 3 by conditioning Shadow Union on the product market competition indicators. The results in columns (5) and (6) of Table 7 are consistent with our prediction. On average, firms facing a lesser degree of competition increase their book (market) leverage ratios by 3.0 (1.7) percentage points (both statistically significant at the $1 \%$ level) whereas firms facing fierce competition increase their leverage ratios by only 0.6 (0.8) percentage points (not statistically significant at the conventional level). These results indicate that the shadow union effect is more pronounced for firms with stronger pricing power, and hence greater union rents. Taken together, the results in Sections 4.1 and 4.2 provide evidence that the heightened threat of new unionization in a local labor market, which is triggered by union victory in one firm, have a sizeable impact on financing decisions of other, non-unionized firms in the same local labor market. 


\section{$5 \quad$ Is It Really a Credible Threat?}

\subsection{The Effect of Shadow Union on Wages}

The results in the previous sections are consistent with the heightened threat of new unionization after union victories within a local labor market. To further confirm whether such heightened threat induced by union victories is credible enough to shape corporate financing decisions, we estimate the effect of a shadow union on wages in local labor markets. ${ }^{28}$ Because much of workers' bargaining power arises from credible threats to limit their labor supply, wages should reflect their enhanced bargaining power. In fact, this is consistent with the rent-sharing models of wages in the literature. For example, Mortensen and Pissarides (2011) show that the equilibrium wages of workers, $w(y)$, are determined by $b+\beta(y-b)$, the sum of their reservation wages $(b)$ and a share of the total surplus, the difference between the productivity $(y)$ and reservation wages (outside option) that is captured by their bargaining weights $(\beta)$.

We obtain data on the average monthly wages of employees in local labor markets over a quarter from the Quarterly Workforce Indicators (QWI). We aggregate county-level data at the commuting zone level to construct the average monthly wages of employees for each commuting zone. We then run the following difference-in-difference regressions in which the

\footnotetext{
${ }^{28}$ It has been well documented in the previous studies that the union threat affects the wages of non-union workers (e.g., Fortin et al., 2019; Taschereau-Dumouchel, forthcoming). Most of these studies exploit the passage of right-to-work legislation by U.S. states as a source of variation in union threat; however, none of them use union victories of other firms (i.e., shadow union) as a source. Since our identification hinges on the formation of shadow union, it is crucial to verify that shadow union indeed heightens threat of new unionization, thereby affecting the wages of (non-union) workers.
} 
unit of observation is commuting zone and year-quarter level:

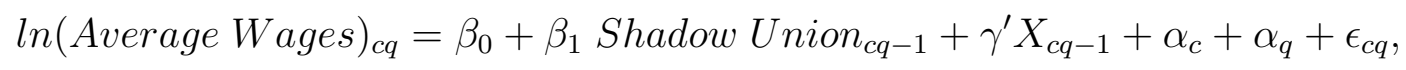

where $c$ indexes commuting zone and $q$ year-quarter; $\ln (\text { Average Wages })_{c q}$ is the $\log$ of average monthly wages (inflation adjusted using CPI-U) of workers in the local labor market $c$ in year-quarter $q ; X_{c q-1}$ is a vector of commuting zone level control variables, and $\alpha_{c}$ and $\alpha_{q}$ indicate a vector of local labor market and year-quarter fixed effects, respectively. Shadow Union $_{c q-1}$ is an indicator variable that equals one if any firm in local labor market $c$ has unionized over the previous five years, and zero otherwise. We use the same five-year horizon as in the baseline specification, Equation (1). The commuting zone level controls include Unemployment Rates and $\ln$ (Population). The details of constructing these variables and the corresponding data sources are described in the appendix. Standard errors are clustered at the local labor market level.

\section{[Insert Panel A of Table 8 here.]}

Columns (1) and (2) of Panel A in Table 8 provide the results from estimating Equation (3). It is worth noting that our identification relies on within local labor market variation in wages around the events (i.e., shadow union organizing). The result in column (1) reveals that shadow unions induce a $1.4 \%$ increase in the average wages in the corresponding local labor market. When the commuting zone level controls are included in the model (column (2)), the point estimate on Shadow Union remains robustly significant and economically large: a $0.9 \%$ increase in the average wages, which is statistically significant at the $1 \%$ level. The average wages include those of workers in unionized firms because the wage variable 
from the QWI is available at the aggregate level. We note, however, that it does not seem plausible that higher wages of workers in a newly organized establishment (or in several establishments) can lead to a $0.9 \%$ increase in the average wages of almost entire employees in the local labor market without affecting wages of non-union workers. Therefore, this finding is consistent with the heightened threat of unionization after the formation of shadow unions in the local labor market. ${ }^{29}$

We also note that not many control variables are available at the commuting zone or county-level. Therefore, to make sure that we include a rich set of important control variables in the wage regressions, we check robustness of the above results using the alternative definition of local labor markets, state-by-industry, for which a large set of state- or industrylevel control variables are available. In columns (3) and (4), we define local labor markets over state by NAICS sector because the QWI data use NAICS industry classifications. We include GDP Growth, Industry Output Growth, and Unemployment Rates to control for differences in economic conditions across different local labor markets that affect wages. We also include Leading Index, which predicts the six-month growth rate of the state's coincident index, in order to incorporate the short-run economic prospects of local labor markets; Home Ownership and ln(Housing Price Growth) to control for the local housing markets; total number of commercial banks (ln(\# of Comm. Banks)) that may affects households' borrowing and consumption decisions; and $\ln$ (Population) and $\ln$ (Population Density). Since

\footnotetext{
${ }^{29}$ An alternative interpretation of our findings is that firms seek to raise capital by issuing debt to afford higher wages. This is hard to reconcile with the theoretical prediction made in Bronars and Deere (1991) that firms use debt to position themselves against potential unions, thereby credibly reducing the funds that are bargained over between unions and firms. Moreover, firms are usually unable to borrow to increase wages because there will be credit rationing due the inalienability of human capital (Hart and Moore, 1994).
} 
there is an overall upward trend in the median real earnings over the sample period, which may, at least partially, be driven by an increased labor productivity due to a better access to higher education. Therefore, we control for the fraction of college-educated workers in each state (Educational Attainment). Finally, we include state- and industry-level union coverage density. ${ }^{30}$ These control variables are lagged by one year or by one quarter depending on the data availability.

In column (4), the coefficient estimate for GDP Growth is 14.270 and is statistically significant at the $1 \%$ level, suggesting that wages are higher in local labor markets with higher GDP growth. A within-local labor market, one-standard-deviation change in GDP Growth is associated with an increase of $0.4 \%$ in wages in local labor markets. The industry-level growth rate of gross output indicates a similar relation between economic growth and wages in local labor markets: the coefficient estimate on Industry Output Growth is positive (0.681) but statistically insignificant. The coefficient on local unemployment rates is negative (-99.897) and significant at the 1\% level: a within-local labor market, one-standard-deviation increase in Unemployment Rates is related to a decrease of $1.7 \%$ in wages. As would be expected, the coefficients on union coverage rates are positive and statistically significant, indicating a positive relation between union coverage and wages. The caveat of these calculations for the economic magnitudes of control variables is that these coefficient estimates would not have causal interpretations. Turning to our main variable of interest, Shadow Union, the result in column (4) indicates that, following the formation of shadow unions, the average wages in the same local labor market increase by $0.6 \%$. The economic magnitude of such a shadow

\footnotetext{
${ }^{30}$ The results are robust to including the state-level minimum wage as an additional regressor.
} 
union effect on wages is larger than that of changes in state-level GDP growth. Thus, the results in Table 8 show that the threat of unionization that is heightened by shadow unions is indeed credible and reflected in the market wages, which further reinforces the heightened threat channel through which shadow unions in local labor markets affect corporate financing decisions.

\subsection{The Effect of Shadow Union on Likelihood of Subsequent Union Victories}

If shadow unions pose a credible threat in the relevant labor market, we may expect an increase in the likelihood of subsequent union victories in the absence of firms' endogenous reactions. Firms, however, respond to the threat of unionization by strategically implementing less conservative financial policies, such as using more debt or holding less cash reserves, or by raising wages as we show in Sections 3.1, 3.2, and 5.1. Thus, in equilibrium, the heightened threat would not be fully reflected in subsequent union organizing activities and their success. To investigate whether and how much union victory of one establishment in the previous period spills over into other establishments in the subsequent period, we run a local labor market-year level regression. More specifically, we regress an indicator variable for union victory in a local labor market at $t$ on its once-lagged variable, a set of control variables, local labor market effects, and time effects. Since the lagged dependent variable and fixed effects are included in the model, we apply the dynamic panel generalized method of moments (GMM) estimation, which controls both for unobserved local labor market specific heterogeneity and for possible endogeneity of the lagged dependent variable. 


\section{[Insert Panels B1 and B2 of Table 8 here.]}

The results are reported in Panels B1 and B2 of Table 8. In Panel B1, we define local labor market using commuting zone and the unit of observation is at the commuting zone-year level. Columns (1) and (2) use the one-step first-difference GMM estimation of Arellano and Bond (1991) which exploits the lagged explanatory variables as instruments. This method is especially suitable for small time-series and large cross-sectional dynamic panel data. The autoregressive coefficient in column (2) is 0.045 and statistically significant at the $1 \%$ level, which indicates that establishments are more likely to be organized by 4.5 percentage points if another establishment in the same labor market had a successful election in the previous year. ${ }^{31}$ This confirms our conjecture that the heightened threat by shadow unions increases the likelihood of subsequent union victories in the relevant labor market, which further supports the heightened threat channel. A test for the first order serial correlation, $\mathrm{AR}(1)$, in the first-differenced residuals confirms that the residuals in the first-differenced equation possess strong serial correlation by construction. ${ }^{32}$ The same test for the second order serial correlation in the first-differenced residuals, $\mathrm{AR}(2)$, indicates that our estimation satisfies the zero-autocorrelation of the residuals in levels. Furthermore, the Hansen's test of overidentifying restrictions cannot reject the null hypothesis with a p-value of 0.930 that the overidentifying restrictions are valid. In columns (3) and (4), we employ two-step system GMM estimation of Blundell and Bond (1998) to check robustness of results in columns (1)

\footnotetext{
${ }^{31}$ In a simple OLS regression without local labor market fixed effects, the lagged dependent variable is positively correlated with the error term due to the unobserved heterogeneity across labor markets, which biases the OLS estimates upward. In the fixed effect regression, the estimated coefficient is biased downward because of the negative sign on the lagged error in the first-differenced error term. In our sample, we confirm that the GMM estimates lie between those from simple OLS and fixed effect regression, which serves as a useful check for the consistency of the GMM estimates.

${ }^{32} \Delta \epsilon_{i, t}=\epsilon_{i, t}-\epsilon_{i, t-1}$ should be negatively correlated with $\Delta \epsilon_{i, t-1}=\epsilon_{i, t-1}-\epsilon_{i, t-2}$ since both of them share the $\epsilon_{i, t-1}$ term.
} 
and (2) since the lagged levels might be poor instruments for the first differenced variables. In column (4) with commuting zone level controls, we obtain similar results: following the formation of shadow union, workers of other establishments in the same labor market are more likely to organize unions in the next year by 9.3 percentage points. In Panel B2, we repeat the same exercise using an alternative definition of labor market, state by industry (two-digit SIC), and obtain qualitatively similar findings. Taken together, the evidence in this section suggests that the threat of unionization triggered by shadow union is indeed credible enough to affect financing policies of non-union firms in the relevant labor market.

\section{Conclusion}

A continuing decline in the rate of union membership and coverage in the U.S. since 1970 has raised the question whether managers and shareholders should continue to consider labor unions in making corporate decisions. In this article, we identify a novel externality of a firm's unionization affecting other, non-union firms in the relevant labor market. In particular, we link a union victory in one firm to financing decisions of peer firms that operate in the same local labor market. The relationship appears to be economically important: following a union victory, the predicted increase in market leverage ratios of non-union firms is about $9 \%$ relative to the sample median. Such shadow union effects are more pronounced when firms experience a greater increase in the probability of workers being organized and when they face higher union rents. This is consistent with a heightened threat of new unionization in the local labor market following the formation of shadow union. These results suggest that an informal labor force, i.e., shadow union, could play an important role in shaping the 
capital structure of non-unionized firms within a local labor market even while membership in formal (traditional) organizations declines.

These results provide direct and large sample evidence for anecdotes that workers in nonunionized firms can pose a credible threat to their employers (managers and shareholders) after observing a successful union election by peer firms in the same local labor market. Although previous work has documented the ripple effect of institutional changes in labor markets (unionization, minimum wage, etc.) on wages and their implications for explanations of earnings inequality (e.g., Rosen, 1969; Lee, 1999; Fortin et al., 2019; TaschereauDumouchel, forthcoming), it has not examined such a spillover effect on financing decisions. To our knowledge this is the first study to suggest that strategic incentives created by union bargaining could spill over into non-union firms within a local labor market and affect their financing decisions. Our identification strategy allows us to isolate and identify union threat effect from financial flexibility effect. Since shadow unions induce firms to internalize their bargaining considerations into financing decisions even before the actual formation of union, our results help explain why the literature has documented the mixed or little impact of unionization on corporate policies. In addition, our identification strategy is less subject to endogeneity concerns because, even though factors that affect the unionization of a firm may correlate with its own financing decisions, it is unlikely that such factors correlate with other firms' capital structure. Finally, we confirm that the heightened threat posed by shadow union is credible enough to shape corporate financing policies: following the formation of shadow unions, both the average wages of employees and the likelihood of subsequent union victories increase in the relevant labor markets, which further reinforces the idea that shadow 
unions affect a firm's strategic choice of less conservative financial policies. 


\section{References}

Abowd, John A. and Thomas Lemieux, "The Effects of Product Market Competition on Collective Bargaining Agreements: The Case of Foreign Competition in Canada," Quarterly Journal of Economics, 1993, 108 (4), 983-1014.

Agrawal, Ashwini K. and David A. Matsa, "Labor Unemployment Risk and Corporate Financing Decisions," Journal of Financial Economics, 2013, 108 (2), 449-470.

Ali, Ashiq, Sandy Klasa, and Eric Yeung, "The Limitations of Industry Concentration Measures Constructed with Compustat Data: Implications for Finance Research," Review of Financial Studies, 2009, 22 (10), 3839-3871.

Arellano, Manuel and Stephen Bond, "Some Tests of Specification for Panel Data: Monte Carlo Evidence and an Application to Employment Equations," Review of Economic Studies, 1991, 58 (2), 277-297.

Artuç, Erhan, Shubham Chaudhuri, and John McLaren, "Trade Shocks and Labor Adjustment: A Structural Empirical Approach," American Economic Review, 2010, 100 (3), 1008-1045.

Autor, David H. and David Dorn, "The Growth of Low-Skill Service Jobs and the Polarization of the US Labor Market," American Economic Review, 2013, 103 (5), 1553-1597.

Bates, Thomas W., Kathleen M. Kahle, and René M. Stulz, "Why Do U.S. Firms Hold So Much More Cash than They Used To?," Journal of Finance, 2009, 64 (5), 1985-2021.

Benmelech, Efraim, Nittai Bergman, and Hyunseob Kim, "Strong Employers and Weak Employees: How Does Employer Concentration Affect Wages?," NBER Working Paper, 2018.

Bivens, Josh, Lora Engdahl, Elise Gould, Teresa Kroeger, Celine McNicholas, Lawrence Mishel, Zane Mokhiber, Heidi Shierholz, Marni von Wilpert, and Valerie Wilson, "How Today's Unions Help Working People: Giving Workers the Power to Improve their Jobs and Unrig the Economy," Economic Policy Institute, August 2017. Blundell, Richard and Stephen Bond, "Initial Conditions and Moment Restrictions in Dynamic Panel Data Models," Journal of Econometrics, 1998, 87 (1), 115-143.

Bradley, Michael, Gregg A. Jarrell, and E. Han Kim, "On the Existence of an Optimal Capital Structure: Theory and Evidence," Journal of Finance, 1984, 39 (3), 857-878.

Brander, James A. and Tracy R. Lewis, "Oligopoly and Financial Structure: The Limited Liability Effect," American Economic Review, 1986, 76 (5), 956-970.

Bronars, Stephen G. and Donald R. Deere, "The Threat of Unionization, the Use of Debt, and the Preservation of Shareholder Wealth," Quarterly Journal of Economics, 
1991, 106 (1), 231-254.

- and - , "Unionization, Incomplete Contracting, and Capital Investment," Journal of Business, 1993, 66 (1), 117-132.

Campello, Murillo, John R. Graham, and Campbell R. Harvey, "The Real Effects of Financial Constraints: Evidence from a Financial Crisis," Journal of Financial Economics, 2010, 97 (3), 470-487.

Card, David, "The Effect of Unions on the Structure of Wages: A Longitudinal Analysis," Econometrica, 1996, 64 (4), 957-979.

Christofides, Louis N. and Andrew J. Oswald, "Real Wage Determination and Rent-Sharing in Collective Bargaining Agreements," Quarterly Journal of Economics, 1992, 107 (3), 985-1002.

DiNardo, John and David S. Lee, "Economic Impacts of New Unionization on Private Sector Employers: 1984-2001," Quarterly Journal of Economics, 2004, 119 (4), 1383-1441.

Farber, Henry S., "The Decline of Unionization in the United States: What can be Learned from Recent Experience?," Journal of Labor Economics, 1990, 8 (1), 75-105.

- and Bruce Western, "Ronald Reagan and the Politics of Declining Union Organization," British Journal of Industrial Relations, 2002, 40 (3), 385-401.

Fortin, Nicole M., Thomas Lemieux, and Neil Lloyd, "Union Spillover Effects and Changes in Wage Inequality," Working Paper, 2019.

Frank, Murray Z. and Vidhan K. Goyal, "Trade-Off and Pecking Order Theories of Debt," Handbook of Empirical Corporate Finance, 2008, pp. 135-202. (Elsevier, Amsterdam).

- and - , "Capital Structure Decisions: Which Factors Are Reliably Important?," Financial Management, 2009, 38 (1), 1-37.

García, Diego and Øyvind Norli, "Geographic Dispersion and Stock Returns," Journal of Financial Economics, 2012, 106 (3), 547-565.

Giroud, Xavier and Holger M. Mueller, "Firm Leverage and Regional Business Cycles," Working Paper, 2018.

Gomes, João, Urban Jermann, and Lukas Schmid, "Sticky Leverage," American Economic Review, 2016, 106 (12), 3800-3828.

Gorodnichenko, Yuriy and Michael Weber, "Are Sticky Prices Costly? Evidence from the Stock Market," American Economic Review, 2016, 106 (1), 165-199.

Guadalupe, Maria, "Product Market Competition, Returns to Skill, and Wage Inequality," Journal of Labor Economics, 2007, 25 (3), 439-474.

Hart, Oliver and John Moore, "A Theory of Debt Based on the Inalienability of Human Capital," Quarterly Journal of Economics, 1994, 109 (4), 841-879. 
Heider, Florian and Alexander Ljungqvist, "As Certain as Debt and Taxes: Estimating the Tax Sensitivity of Leverage from State Tax Changes," Journal of Financial Economics, 2015, 118 (3), 684-712.

Hirsch, Barry T. and David A. Macpherson, "Union Membership and Coverage Database from the Current Population Survey: Note," Industrial and Labor Relations Review, 2003, 56 (2), 349-354.

Holmes, Thomas J., "Geographic Spillover of Unionism," NBER Working Paper, 2006.

Johnson, Kenneth P and John R Kort, "2004 Redefinition of the BEA Economic Areas," Survey of Current Business, 2004, 84 (11), 68-75.

Kambourov, Gueorgui, "Labour Market Regulations and the Sectoral Reallocation of Workers: The Case of Trade Reforms," Review of Economic Studies, 2009, 76 (4), 1321-1358.

Klasa, Sandy, William F. Maxwell, and Hernán Ortiz-Molina, "The Strategic Use of Corporate Cash Holdings in Collective Bargaining with Labor Unions," Journal of Financial Economics, 2009, 92 (3), 421-442.

Leary, Mark T. and Michael R. Roberts, "Do Peer Firms Affect Corporate Financial Policy?," Journal of Finance, 2014, 69 (1), 139-178.

Lee, David S., "Wage Inequality in the United States during the 1980s: Rising Dispersion or Falling Minimum Wage?," Quarterly Journal of Economics, 1999, 114 (3), 977-1023.

- and Alexandre Mas, "Long-Run Impacts of Unions on Firms: New Evidence from Financial Markets, 1961-1999," Quarterly Journal of Economics, 2012, 127 (1), 333-378. - and Thomas Lemieuxa, "Regression Discontinuity Designs in Economics," Journal of Economic Literature, 2010, 48 (2), 281-355.

Lemmon, Michael L., Michael R. Roberts, and Jaime F. Zender, "Back to the Beginning: Persistence and the Cross-Section of Corporate Capital Structure," Journal of Finance, 2008, 63 (4), 1575-1608.

Lin, Chen, Thomas Schmid, and Yuhai Xuan, "Employee Representation and Financial Leverage," Journal of Financial Economics, 2018, 127 (2), 303-324.

MacKay, Peter and Gordon M. Phillips, "How Does Industry Affect Firm Financial Structure?," Review of Financial Studies, 2005, 18 (4), 1433-1466.

Manning, Alan and Barbara Petrongolo, "How Local Are Labor Markets?

Evidence from a Spatial Job Search Model," American Economic Review, 2017, 107 (10), 2877-2907.

Matsa, David A., "Capital Structure as a Strategic Variable: Evidence from Collective Bargaining," Journal of Finance, 2010, 65 (3), 1197-1232.

Molloy, Raven, Christopher L Smith, and Abigail K Wozniak, "Declining 
Migration within the U.S.: The Role of the Labor Market," NBER Working Paper, 2014. Mortensen, Dale and Christopher Pissarides, "Job Matching, Wage Dispersion, and Unemployment," OUP Catalogue, Oxford University Press 2011.

Perotti, Enrico C. and Kathryn E. Spier, "Capital Structure as a Bargaining Tool: The Role of Leverage in Contract Renegotiation," American Economic Review, 1993, 83 (5), 1131-1141.

Qiu, Yue, "Debt Structure as a Strategic Bargaining Tool," Working Paper, 2017. Rajan, Raghuram G. and Luigi Zingales, "What Do We Know about Capital Structure? Some Evidence from International Data," Journal of Finance, 1995, 50 (5), 1421-1460.

Rose, Nancy L., "Labor Rent Sharing and Regulation: Evidence from the Trucking Industry," Journal of Political Economy, 1987, 95 (6), 1146-1178.

Rosen, S., "Trade Union Power, Threat Effects and the Extent of Organization," Review of Economic Studies, 1969, 36 (2), 185-196.

Schmalz, Martin C, "Unionization, Cash, and Leverage," CEPR Discussion Paper No. DP12595, 2018.

Serfling, Matthew, "Firing Costs and Capital Structure Decisions," Journal of Finance, 2016, 71 (5), 2239-2286.

Simintzi, E., V. Vig, and P. Volpin, "Labor Protection and Leverage," Review of Financial Studies, 2015, 28 (2), 561-591.

Taschereau-Dumouchel, Mathieu, "The Union Threat," Review of Economic Studies, forthcoming.

Tolbert, Charles M. and Molly Sizer, "U.S. Commuting Zones and Labor Market Areas: A 1990 Update," Economic Research Service Staff Paper 9614, 1996.

Welch, Ivo, "Two Common Problems in Capital Structure Research: The Financial-Debt-To-Asset Ratio and Issuing Activity Versus Leverage Changes," International Review of Finance, 2011, 11 (1), 1-17.

Windmeijer, Frank, "A Finite Sample Correction for the Variance of Linear Efficient Two-Step GMM Estimators," Journal of Econometrics, 2005, 126 (1), 25-51.

Yates, Michael D., Why Unions Matter, New York: Monthly Review Press, 2009.

Ömer Tuğrul Açıkgöz and Barış Kaymak, "The Rising Skill Premium and Deunionization," Journal of Monetary Economics, 2014, 63, 37-50. 


\section{Appendix: Variable Definitions}

\begin{tabular}{ll}
\hline Variables & Definition [Compustat designations where appropriate] \\
\hline $\begin{array}{l}\text { Percentage Votes } \\
\text { in Support of Union }\end{array}$ & The ratio of the number of votes for unionionization to the \\
& number of eligible voters or the sum of votes for \\
unionionization and against unionionization, whichever is & Areatericator variable that equals one if a firm is unionized as a \\
Passage & result of an election (i.e., Percentage Votes in Support of Union \\
& is greater than or equal to 50\%), and zero otherwise \\
& Total number of union elections in each commuting zone for \\
the period 1977 to 2010 & \\
Number of Elections & Total number of successful (i.e., Passage = 1) union elections \\
& in each commuting zone for the period 1977 to 2010 \\
& Total debt divided by the sum of total debt and book value \\
of equity in percentage. Book value of equity is the sum of & total value of common equity [CEQ] and deferred tax [TXDB]. \\
& Total debt is book value of long-term debt [DLTT] plus debt \\
& in current liabilities [DLC]. \\
& Total debt divided by the sum of total debt and market value \\
of equity in percentage where market value of equity is com- & mon shares outstanding [CSHO] times fiscal-year closing price \\
[PRCC_F]
\end{tabular}

Alternative Book Leverage

Alternative Market Leverage

Shadow Union

Tangibility

Market-to-Book

$\ln$ (Sales)

Modified Z-score

Return on Assets
Total debt divided by book value of assets $[\mathrm{AT}]$ in percentage

Total debt divided by market value of assets in percentage where market value of assets is the sum of market value of equity and book value of assets minus book value of equity

An indicator variable that equals one if another firm in the same local labor market passes union election over the previous five years, and zero otherwise

Net property, plant, and equipment [PPENT] nomalized by book value of assets

The ratio of market value of assets to book value of assets

The log of sales [SALE] (adjusted in constant 2017 dollars using the CPI-U)

$3.3 \times$ (earnings before interest and tax [EBIT] / total assets) $+1.0 \times($ sales $/$ total assets $)+1.4 \times($ retained earnings $[\mathrm{RE}] /$ total assets $)+1.2 \times($ working capital $[\mathrm{WCAP}] /$ total assets $)$ (Campello et al., 2010)

Earnings before interest, tax, depreciation and amortization [EBITDA] scaled by book value of assets 
Cash Holdings

Cash Flow

Net Working Capital

Capital Expenditure

Leverage

Acquisitions

$\ln$ (Assets)

Ind. CF Volatility

RESD Expenditures

Dividend Dummy

Pseudo Shadow Union

Shadow Union $3 Y R(7 Y R)$

High (Low) Median Wage

Shadow Union ${ }^{\text {Multi (Single) }}$
The ratio of cash and short-term investments [CHE] to total assets in percentage

Earnings after interest, dividends, and tax but before depreciation [OIBDP - XINT - TXT - DVC], scaled by total assets

Working capital minus cash and short-term investments, scaled by total assets

The ratio of capital expenditures [CAPX] to total assets

Total debt (book value of long-term debt plus debt in current liabilities) divided by book value of assets

The ratio of Acquisitions $[\mathrm{AQC}]$ to total assets

The log of total assets (adjusted in constant 2017 dollars using the CPI-U)

Industry cash flow volatility, calculated as the industry (SIC two-digit) average of standard deviation of firm-level cash flow to assets for the previous twenty years (we require at least five observations for each firm)

The ratio of $R \& D$ expenses $[X R D]$ to sales; it is set to zero when $R \& D$ expenses are missing

An indicator variable that equals one in years in which a firm pays common dividends [DVC], and zero otherwise

An indicator variable equal to one if another firm in the same pseudo local labor market passes union election during the previous five years, and zero otherwise. We randomly assign a firm's local labor market (a commuting zone where its headquarters is located) by maintaining a cross-sectional distribution of firms in local labor markets and a panel structure of successful union elections.

An indicator variable that equals one if another firm in the same local labor market passes union election during the previous three (seven) years, and zero otherwise

An indicator variable that equals one if the time-series average of industry-level annual median wages is above (below) the median of the distribution, zero otherwise. We use industry-level annual median wage data from the Occupational Employment Statistics (OES) Survey by the Bureau of Labor Statistics. The OES data before 1997 contain no wage estimates. The data use SIC three-digit industry classification for 1997-2001 and NAICS four-digit classification for 2002 to present.

An indicator variable that equals one if other firms in the same local labor market passes multiple (single) union elections during the previous five years, and zero otherwise 
High (Low) Union Rents

$\ln$ (Average Wages)

Unemployment Rates

$\ln$ (Population)
An indicator variable that equals one if a firm faces high (low) union rents, and zero otherwise. We use the following three indicators to identify firms with high (low) union rents: high (low) labor intensity, low (high) unemployment rate, and low (high) product market competition. First, High (Low) Labor Intensity is an indicator variable that equals one if a firm operates in the industry with above-median (below-median) labor intensity, and zero otherwise. We measure industry-level (SIC three-digit) labor intensity as follows: we first calculate the cross-sectional average of the ratios of total staff expense [XLR] to sales for each industry-year observation; we then define industry-level labor intensity as ten year moving average of labor intensity over the past 10 years. Second, High (Low) Unemployment is an indicator variable that equals one if the unemployment rate of the state in which a firm headquartered is above (below) the median of the distribution for a given year, and zero otherwise. We obtain the state-level unemployment rate from the Bureau of Labor Statistics. Third, High (Low) $P M C$ is an indicator variable that equals one if a firm operates in the industry with above-median (below-median) product market competition for a given year, zero otherwise. As suggested by Ali et al. (2009), we use Herfindahl-Hirschman index for the 50 largest companies collected from the Census of Manufacturers publications by the U.S. Census Bureau, which are based on all public and private firms in manufacturing industries. The data are based on four-digit SIC industries for the years 1982 to 1992 and six-digit NAICS industries for the years 1997 to 2012. Since the Census of Manufacturers is published only in every five years, we apply the Census data for a given year to the two years immediately before and after it, following Ali et al. (2009).

The log of average monthly earnings of employees with stable jobs (i.e., worked with the same firms throughout the quarter) in the local labor markets. We define local labor markets either at the commuting zone level or at the state by industry (NAICS sector) level since the QWI uses the 2012 NAICS codes for industry classification. The wage date are from the Quarterly Workforce Indicators.

Commuting zone-(or state-)level annual unemployment rate from the Bureau of Labor Statistics; Commuting zone-level unemployment rate is calculated from the county-level data.

The log of commuting zone-(or state-)level total population from the GeoFRED; Commuting zone-level total population is calculated from the county-level data. 
GDP Growth

Industry Output Growth

Leading Index

Home Ownership

$\ln$ (\# of Comm. Banks)

ln(Housing Price Growth)

$\ln ($ Population Density)

Educational Attainment

Industry Union Coverage

State Union Coverage

$\mathbb{1}_{\{\exists \text { Union Victory at } t\}}$
State-level annual growth rate of real GDP from the Bureau of Economic Analysis

Industry-level annual growth rate of gross output from the $\mathrm{Bu}-$ reau of Economic Analysis

State-level annual leading index from the GeoFRED (Geographical Economic data) provided by the Federal Reserve Bank of St. Louis

State-level annual home ownership rate from the GeoFRED

The log of state-level total number of commercial banks from the GeoFRED

The log of state-level quarterly growth rate of housing price index (all transactions, in percentage change) from the Federal Housing Finance Agency (FHFA)

The log of state-level population density from the RAND Corporation

The percentage of the population 25 years and over with Bachelor's degree or higher by state from the GeoFRED and U.S. Census Bureau (Current Population Survey)

Industry-level union coverage density from Hirsch and Macpherson (2003). Union coverage density is the percentage of employed workers covered by a collective bargaining agreement.

State-level union coverage density from Hirsch and Macpherson (2003)

An indicator variable that equals one if there is at least one successful union election in a local labor market at year $t$, zero otherwise 


\section{Figure 1: Union Membership and Collective Bargaining Coverage Among Pri- vate Sector Workers}

\section{Panel A. Union Membership by Year}

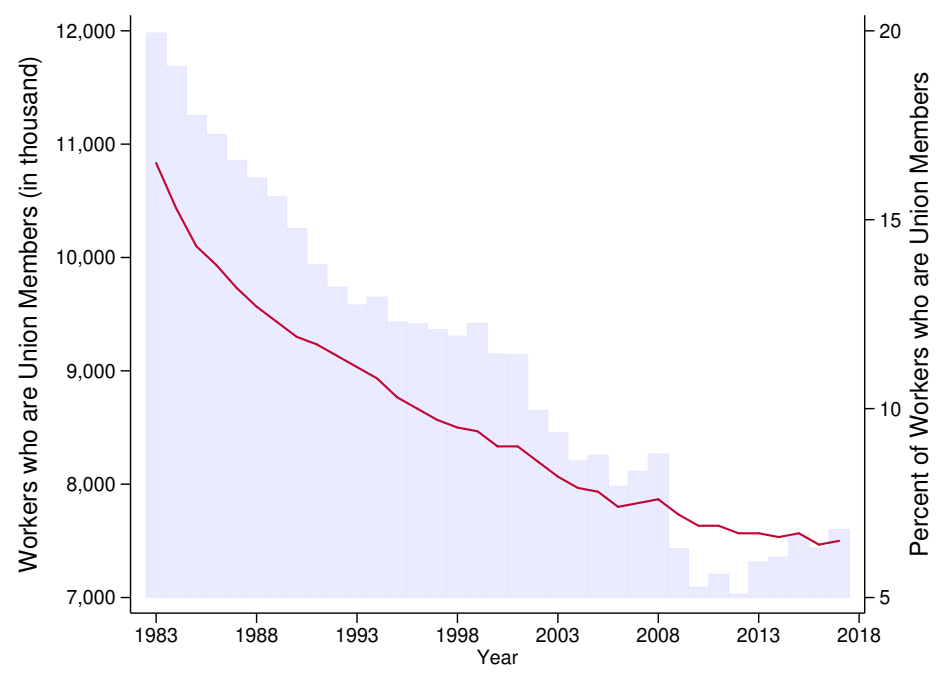

Panel B. Collective Bargaining Coverage by Year

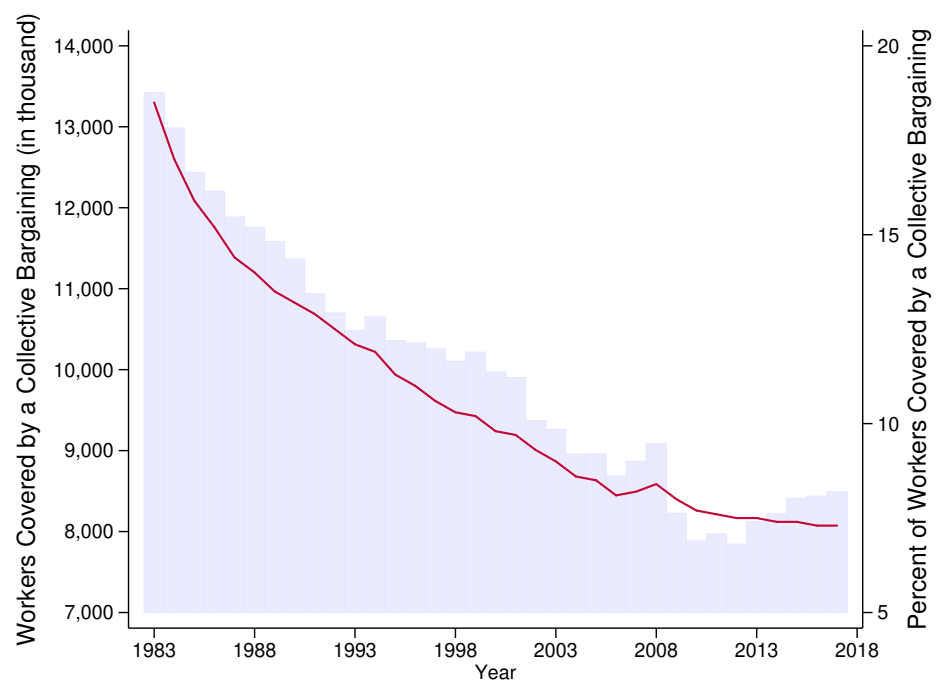

These figures present union membership and collective bargaining coverage for private sector workers from 1983 to 2017 from Hirsch and Macpherson (2003). Panel A plots the total number of employed workers who are union members in thousands (blue bars) and the percentage of employed workers who are union members (red line). Panel B plots the total number of employed workers who are covered by a collective bargaining agreement in thousands (blue bars) and the percentage of employed workers covered by a collective bargaining agreement (red line). Note that workers who are not union members could be covered by a collective bargaining agreement. 


\section{Figure 2: Occurrence and Results of Union Elections}

Panel A. Number of Union Elections, Percentage Votes in Support of Union, and Percentage of Successful Elections by Year

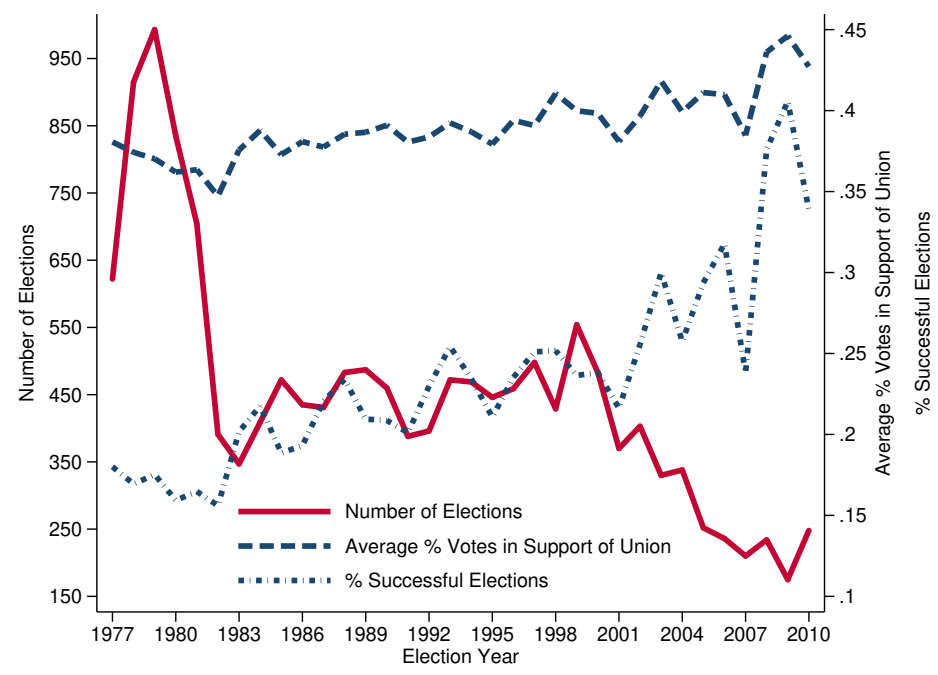

Panel B. Distribution of Percentage Votes in Support of Union

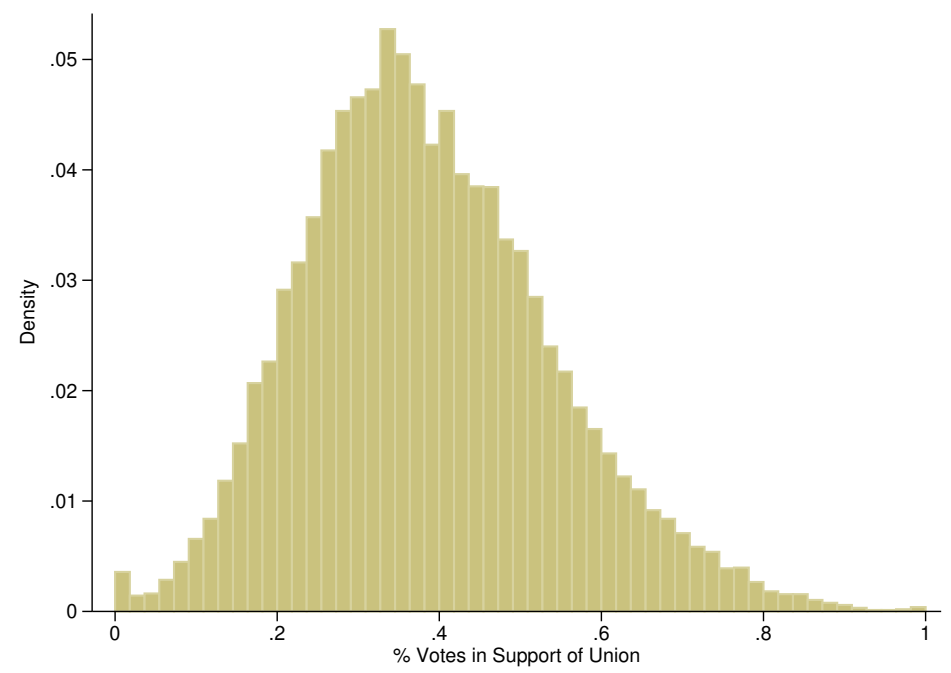

These figures show the occurrence and results of union election for the period 1977 to 2010 from the National Labor Relations Board (NLRB). Panel A plots the number of union elections, average percentage votes in support of union, and percentage of successful elections by year. Our sample consists of a total of 15,369 unique union elections by both public and private firms. The details of data collection process are provided in Section 2.1.1. Percentage Votes in Support of Union is calculated as a ratio of the number of votes for unionization to the number of eligible voters or the sum of votes for unionization and against unionization, whichever is greater. We define successful elections as those with Percentage Votes in Support of Union being greater than or equal to 50\%. Panel B plots the distribution of Percentage Votes in Support of Union. 

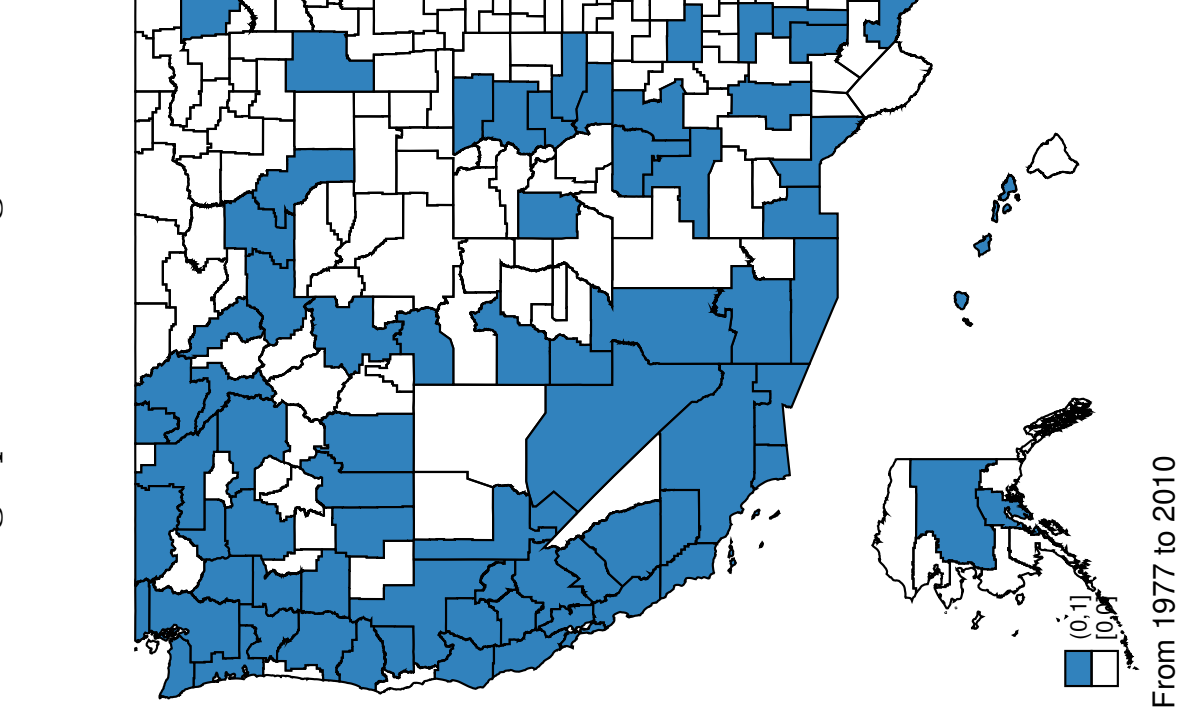

$\exists$.

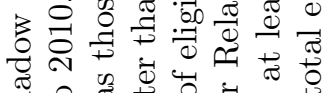

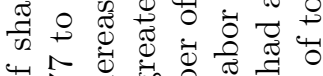

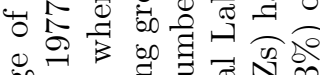

ॠँ:

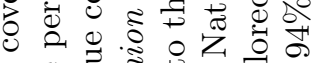
.

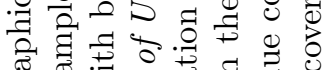

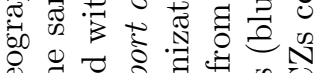

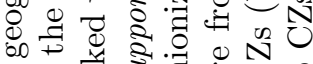
\& ఫै

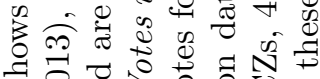
जी

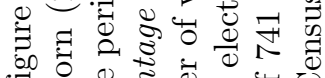
我

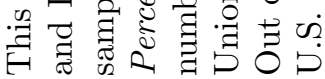




\title{
Figure 4: Dynamics of Leverage Ratios Around Successful Union Elections by Other Firms in the Same Local Labor Market: Shadow Union Effects
}

\author{
Panel A. Without Centering to Pre-Event Mean Leverage Ratios
}

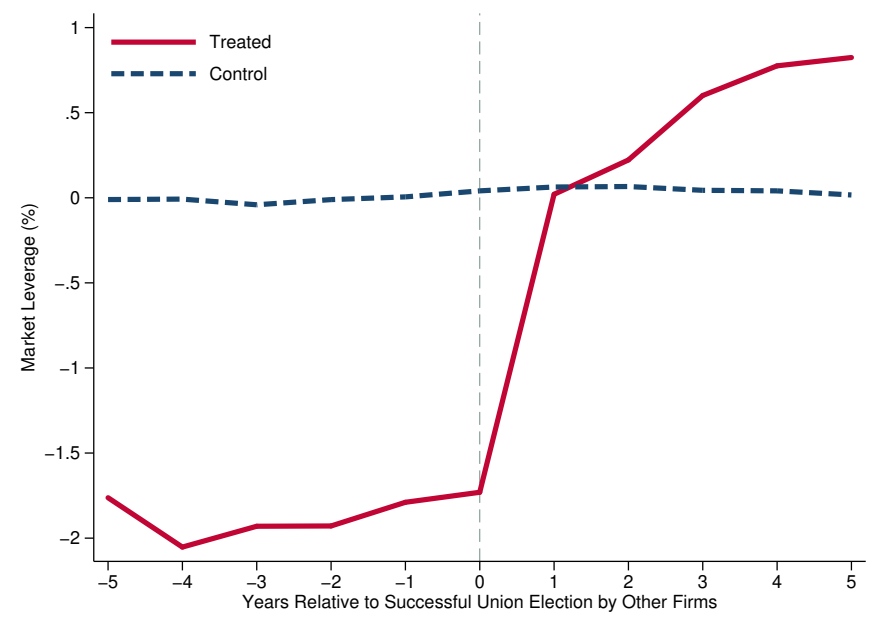

\section{Panel B. With Centering to Pre-Event Mean Leverage Ratios}

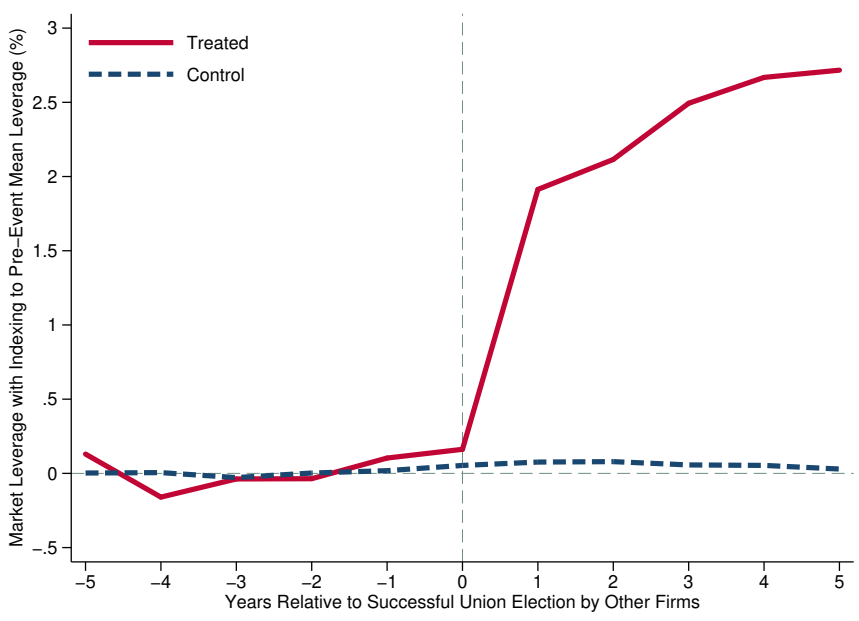

These figures show and compare the within-firm variation in the market leverage ratios, net of changes in aggregate macroeconomic conditions (i.e., net of cross-sectional average for each year), for the treated firms (red solid line) and control firms (blue dotted line). Treated firms are those in a local labor market in which another firm successfully passes union election in year $t$. Control firms are those in other local labor markets where none of the firms pass union election during the five years before and after year $t$. We define local labor markets at the commuting zone level. We do not include any firms with multiple shadow union events from year $t-5$ to $t+5$ in the treated group. In Panel $\mathrm{A}$, the $\mathrm{y}$-axis indicates the average of within-firm variation in Market Leverage as a percentage, and the $\mathrm{x}$-axis refers to years relative to shadow union organizing (i.e., successful union elections by other firms). Market Leverage is the total debt divided by the sum of total debt and market value of equity. In Panel B, we center the graphs to their respective mean leverage ratios during the pre-event period (from year $t-5$ to $t-1$ ), so that the y-axis represents the market leverage relative to the pre-event mean leverage ratio. 


\section{Figure 5: Effects of Shadow Union on Financial Leverage: Placebo Tests}

\section{Panel A. Book Leverage}

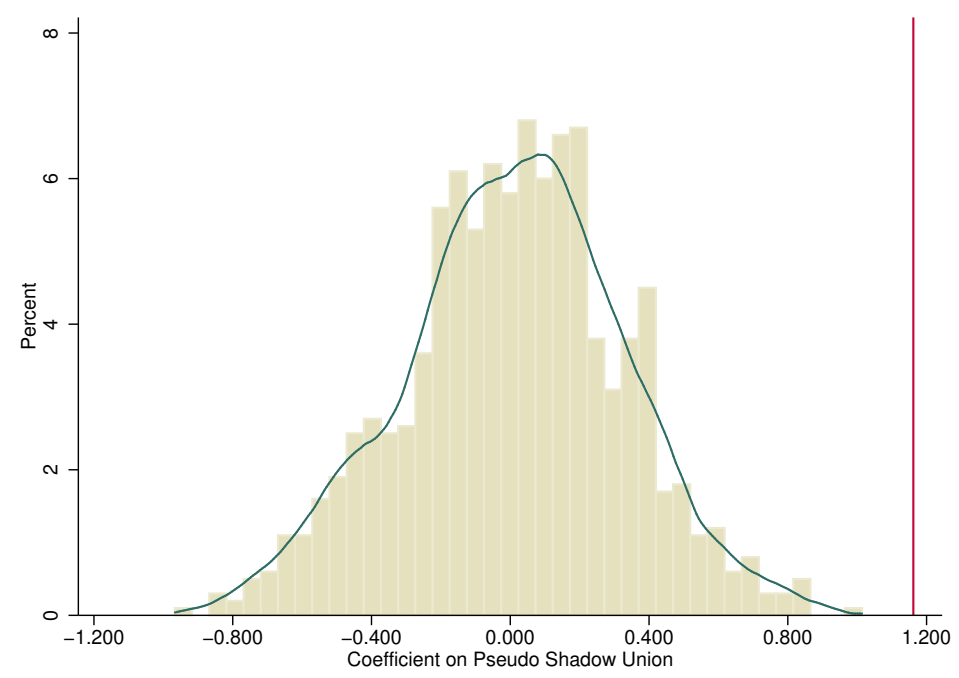

Panel B. Market Leverage

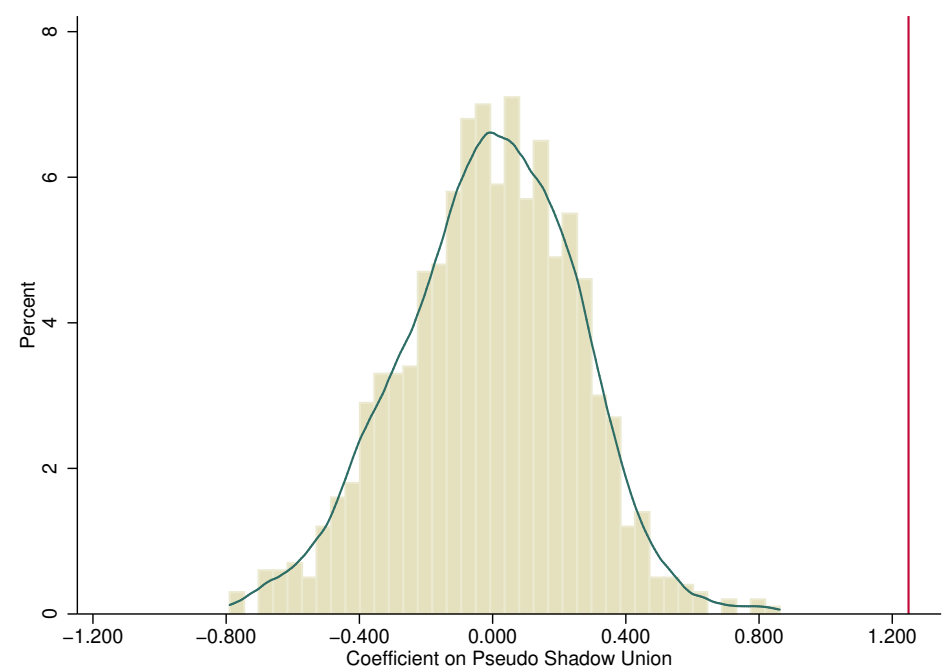

These figures plot the empirical distribution of the coefficient on Pseudo Shadow Union when estimating Equation (2) 1,000 times using the bootstrapped sample. We randomly assign a firm's local labor market (a commuting zone where its headquarters is located) by maintaining a cross-sectional distribution of firms in local labor markets and a panel structure of successful union elections. Pseudo Shadow Union is an indicator variable that equals one if another firm in the same pseudo local labor market passes union election during the previous five years, and zero otherwise. Panels A and B reports the coefficient estimates for Book Leverage and Market Leverage, respectively. The green lines show kernel densities and the vertical red lines present the actual estimates obtained from the regressions based on the actual data (columns (3) and (6) of Panel A in Table 3). Standard errors are clustered by firm. 


\section{Table 1: Descriptive Statistics on Union Elections}

These tables present descriptive statistics on union elections for the period 1977 to 2010 from the National Labor Relations Board (NLRB). We exclude elections for which outcomes are not available and those in which multiple labor organizations competed. We focus on elections of the type RC (Certification of Representative Petition), which refers to a petition filed by an employee or group of employees, or any individual or labor organization acting on their behalf, to certify a representative for collective bargaining in an appropriate unit. Following Lee and Mas (2012), we eliminate elections if the number of eligible voters is less than 100. We require elections to have valid information on the location of employer's plant to identify their corresponding local labor markets. Our final sample consists of a total of 15,369 unique union elections in both public and private firms. Panels A and B are based on the election-level data and Panel $\mathrm{C}$ is based on the aggregated commuting zone-level data. In Panels A and $\mathrm{B}$, Percentage Votes in Support of Union is calculated as a ratio of the number of votes for unionionization to the number of eligible voters or the sum of votes for unionionization and against unionionization, whichever is greater; Passage is an indicator variable that equals one if a firm is unionized as a result of an election (i.e., Percentage Votes in Support of Union is greater than or equal to 50\%), and zero otherwise. In Panel C, Percentage Votes in Support of Union and Passage are the average values for each commuting zone.

Panel A. Election-Level Distribution

\begin{tabular}{lcccccc}
\hline Variables & P25 & Median & Mean & P75 & Std.Dev. & Num.Obs. \\
\hline Percentage Votes in Support of Union & 0.278 & 0.371 & 0.386 & 0.483 & 0.154 & 15,369 \\
Passage & 0.000 & 0.000 & 0.220 & 0.000 & 0.414 & 15,369 \\
\hline
\end{tabular}

Panel B. Election-Level Distribution By Industry

\begin{tabular}{|c|c|c|c|c|c|}
\hline \multirow[b]{2}{*}{ SIC Division } & \multicolumn{2}{|c|}{$\begin{array}{l}\text { Percentage Votes } \\
\text { in Support of Union }\end{array}$} & \multicolumn{2}{|c|}{ Passage } & \multirow[b]{2}{*}{ Num.Obs. } \\
\hline & Mean & Std.Dev. & Mean & Std.Dev. & \\
\hline Agriculture, Forestry and Fishing & 0.372 & 0.168 & 0.167 & 0.379 & 30 \\
\hline Mining & 0.361 & 0.137 & 0.126 & 0.334 & 103 \\
\hline Construction & 0.359 & 0.194 & 0.234 & 0.424 & 321 \\
\hline Manufacturing & 0.379 & 0.145 & 0.188 & 0.391 & 7,380 \\
\hline $\begin{array}{l}\text { Transportation, Communications, } \\
\text { Electric, Gas and Sanitary service }\end{array}$ & 0.399 & 0.160 & 0.260 & 0.439 & 1,605 \\
\hline Wholesale Trade & 0.360 & 0.141 & 0.159 & 0.366 & 637 \\
\hline Retail Trade & 0.345 & 0.150 & 0.158 & 0.365 & 644 \\
\hline Finance, Insurance and Real Estate & 0.333 & 0.129 & 0.112 & 0.317 & 107 \\
\hline Services & 0.405 & 0.163 & 0.280 & 0.449 & 4,321 \\
\hline Public Administration & 0.443 & 0.192 & 0.395 & 0.495 & 38 \\
\hline Non-classifiable & 0.392 & 0.151 & 0.224 & 0.418 & 183 \\
\hline
\end{tabular}

Panel C. Commuting Zone-Level Distribution

\begin{tabular}{lcccccc}
\hline Variables & P25 & Median & Mean & P75 & Std.Dev. & Num.Obs. \\
\hline Percentage Votes in Support of Union & 0.340 & 0.381 & 0.382 & 0.414 & 0.084 & 579 \\
Passage & 0.000 & 0.182 & 0.211 & 0.286 & 0.213 & 579 \\
Number of Elections & 1.000 & 5.000 & 20.100 & 16.000 & 58.685 & 741 \\
Number of Successful Elections & 0.000 & 1.000 & 4.412 & 3.000 & 14.692 & 741 \\
\hline
\end{tabular}




\section{Table 2: Descriptive Statistics on Firm-Year Observations}

This table provides descriptive statistics for firm-year observations of our final sample between 1978 and 2015. We exclude financial firms and require that all firm-years have nonmissing data for the relevant variables used in our analysis. We measure financial leverage (in percentage) in four ways. Book Leverage is the debt-to-capital ratio, defined as the total debt divided by the sum of total debt and book value of equity. The total debt is the sum of long-term debt and debt in current liabilities. Alternative Book Leverage is computed as the total debt divided by the book value of total assets. Market leverage is the ratio of total debt to the sum of total debt and market value of equity. Alternative Market leverage is the total debt divided by the market value of assets in which the market value of assets is the sum of market value of equity and book value of assets minus book value of equity. Following Lemmon et al. (2008), we also require both book and market leverage to lie in the closed unit interval, [0,1]. Shadow Union: Commuting Zone (State by Industry) is an indicator variable that equals one if another firm in the same local labor market, i.e., commuting zone (State by Industry), passes union election over the previous five years, and zero otherwise. We winsorize all unbounded variables at the top and bottom one percent. The details of construction of all other variables are described in the appendix.

\begin{tabular}{lcccccc}
\hline Variables & P25 & Median & Mean & P75 & Std.Dev. & Num.Obs. \\
\hline Book Leverage & 3.972 & 25.521 & 28.663 & 46.327 & 25.107 & 156,250 \\
Market Leverage & 1.465 & 14.657 & 22.230 & 36.764 & 23.353 & 156,250 \\
Alternative Book Leverage & 2.839 & 18.433 & 21.242 & 34.242 & 19.051 & 156,247 \\
Alternative Market Leverage & 1.259 & 11.832 & 17.139 & 28.037 & 17.782 & 156,250 \\
Shadow Union: Commuting Zone & 1.000 & 1.000 & 0.828 & 1.000 & 0.377 & 156,250 \\
Shadow Union: State by Industry & 0.000 & 0.000 & 0.224 & 0.000 & 0.417 & 158,280 \\
Tangibility & 0.097 & 0.225 & 0.291 & 0.425 & 0.238 & 156,250 \\
Market-to-Book & 1.015 & 1.374 & 2.130 & 2.205 & 2.516 & 156,250 \\
ln(Sales) & 3.412 & 5.084 & 5.021 & 6.714 & 2.408 & 156,250 \\
Modified Z-Score & 0.458 & 1.691 & 0.716 & 2.660 & 4.252 & 156,250 \\
Return on Assets & 0.008 & 0.105 & 0.033 & 0.167 & 0.282 & 156,250 \\
\hline
\end{tabular}




\section{Table 3: Effect of Shadow Union on Financial Leverage}

These tables present the effects of unionization of one firm on the capital structure of the other, nonunionized firms in the same local labor markets for the sample period 1978 to 2015. Union election data are from the National Labor Relations Board (NLRB) for the period 1977 to 2010. In Panel A, following Autor and Dorn (2013), we use commuting zones to identify local labor markets while, in Panel B, we define local labor markets at the state by industry (SIC two-digit) level. In columns (1) to (3), the dependent variable is Book Leverage, while in columns (4) to (6) the dependent variable is Market Leverage. Book Leverage is the debt-to-capital ratio, defined as the total debt divided by the sum of total debt and book value of equity. The total debt is the sum of long-term debt and debt in current liabilities. Market leverage is the ratio of total debt to the sum of total debt and market value of equity. Following Lemmon et al. (2008), we require both book and market leverage to lie in the closed unit interval, [0,1]. Shadow Union is an indicator variable that equals one if another firm in the same local labor market passes union election during the previous five years, and zero otherwise. Once a firm recognizes a union in year $t$, subsequent year observations thereafter (all years after year $t$ ) are removed from our sample. We include following firm-level time-varying control variables: the proportion of fixed assets, Tangibility; market-to-book ratio, Market-to-Book; log of sales, $\ln$ (Sales); modified Altman's z-score, Modified Z-Score; and return on assets, Return on Assets. We winsorize all unbounded variables at the top and bottom one percent. The details of construction of these variables are described in the appendix. Numbers in parentheses are standard errors that are clustered by firm. ${ }^{* * *},{ }^{* *}$, and $*$ indicate significance at the $1 \%, 5 \%$, and $10 \%$ levels, respectively.

Panel A. Local Labor Markets Defined Over Commuting Zone (CZ)

\begin{tabular}{|c|c|c|c|c|c|c|}
\hline & \multicolumn{3}{|c|}{ Book Leverage } & \multicolumn{3}{|c|}{ Market Leverage } \\
\hline & $(1)$ & $(2)$ & (3) & $(4)$ & $(5)$ & (6) \\
\hline Shadow Union & $\begin{array}{c}.899^{* * *} \\
(.272)\end{array}$ & $\begin{array}{c}1.077^{* * *} \\
(.310)\end{array}$ & $\begin{array}{c}1.162^{* * *} \\
(.303)\end{array}$ & $\begin{array}{c}.910^{* * *} \\
(.230)\end{array}$ & $\begin{array}{c}1.255^{* * *} \\
(.264)\end{array}$ & $\begin{array}{c}1.249^{* * *} \\
(.258)\end{array}$ \\
\hline Tangibility & $\begin{array}{c}22.806^{* * *} \\
(1.045)\end{array}$ & $\begin{array}{c}23.249^{* * *} \\
\quad(1.047)\end{array}$ & $\begin{array}{c}22.882^{* * *} \\
(1.036)\end{array}$ & $\begin{array}{c}19.034^{* * *} \\
(.870)\end{array}$ & $\begin{array}{c}20.577^{* * *} \\
(.884)\end{array}$ & $\begin{array}{c}19.038^{* * *} \\
(.864)\end{array}$ \\
\hline Market-to-Book & $\begin{array}{c}-.690^{* * *} \\
(.044)\end{array}$ & $\begin{array}{c}-.732^{* * *} \\
(.043)\end{array}$ & $\begin{array}{c}-.701^{* * *} \\
(.044)\end{array}$ & $\begin{array}{c}-1.607^{* * *} \\
(.044)\end{array}$ & $\begin{array}{c}-1.683^{* * *} \\
(.045)\end{array}$ & $\begin{array}{c}-1.603^{* * *} \\
(.044)\end{array}$ \\
\hline $\ln ($ Sales) & $\begin{array}{c}3.934^{* * *} \\
(.163)\end{array}$ & $\begin{array}{c}4.178^{* * *} \\
(.164)\end{array}$ & $\begin{array}{c}3.983^{* * *} \\
(.163)\end{array}$ & $\begin{array}{c}3.462^{* * *} \\
(.129)\end{array}$ & $\begin{array}{c}3.628^{* * *} \\
(.131)\end{array}$ & $\begin{array}{c}3.487^{* * *} \\
(.131)\end{array}$ \\
\hline Modified Z-Score & $\begin{array}{c}-.913^{* * *} \\
(.053)\end{array}$ & $\begin{array}{c}-.892^{* * *} \\
(.053)\end{array}$ & $\begin{array}{c}-.919^{* * *} \\
(.053)\end{array}$ & $\begin{array}{c}-.428^{* * *} \\
(.033)\end{array}$ & $\begin{array}{c}-.422^{* * *} \\
(.032)\end{array}$ & $\begin{array}{c}-.433^{* * *} \\
(.033)\end{array}$ \\
\hline Return on Assets & $\begin{array}{c}-6.030^{* * *} \\
(.586)\end{array}$ & $\begin{array}{c}-6.247^{* * *} \\
(.582)\end{array}$ & $\begin{array}{c}-6.046^{* * *} \\
(.584)\end{array}$ & $\begin{array}{c}-9.388^{* * *} \\
(.431)\end{array}$ & $\begin{array}{c}-9.729^{* * *} \\
(.434)\end{array}$ & $\begin{array}{c}-9.330^{* * *} \\
(.431)\end{array}$ \\
\hline Firm Fixed Effects & Yes & Yes & Yes & Yes & Yes & Yes \\
\hline Industry-by-Year Fixed Effects & Yes & No & Yes & Yes & No & Yes \\
\hline State-by-Year Fixed Effects & No & Yes & Yes & No & Yes & Yes \\
\hline Observations & 156,250 & 156,250 & 156,250 & 156,250 & 156,250 & 156,250 \\
\hline Adjusted $R^{2}$ & .600 & .594 & .602 & .662 & .651 & .664 \\
\hline
\end{tabular}




\section{Table 3: Effect of Shadow Union on Financial Leverage (continued)}

Panel B. Local Labor Markets Defined Over State by Industry

\begin{tabular}{|c|c|c|c|c|c|c|}
\hline & \multicolumn{3}{|c|}{ Book Leverage } & \multicolumn{3}{|c|}{ Market Leverage } \\
\hline & $(1)$ & $(2)$ & $(3)$ & (4) & $(5)$ & $(6)$ \\
\hline \multirow[t]{2}{*}{ Shadow Union } & $.609^{* *}$ & $.733^{* * *}$ & $.567^{* *}$ & $.828^{* * *}$ & $.900^{* * *}$ & $.717^{* * *}$ \\
\hline & $(.252)$ & $(.256)$ & $(.258)$ & $(.216)$ & $(.220)$ & $(.223)$ \\
\hline \multirow[t]{2}{*}{ Tangibility } & $22.933^{* * *}$ & $23.358^{* * *}$ & $22.990^{* * *}$ & $19.129^{* * *}$ & $20.676^{* * *}$ & $19.133^{* * *}$ \\
\hline & $(1.038)$ & $(1.042)$ & $(1.030)$ & $(.865)$ & $(.879)$ & $(.860)$ \\
\hline \multirow[t]{2}{*}{ Market-to-Book } & $-.688^{* * *}$ & $-.731^{* * *}$ & $-.701^{* * *}$ & $-1.608^{* * *}$ & $-1.685^{* * *}$ & $-1.605^{* * *}$ \\
\hline & $(.044)$ & $(.043)$ & $(.044)$ & $(.044)$ & $(.045)$ & $(.044)$ \\
\hline \multirow[t]{2}{*}{$\ln ($ Sales $)$} & $3.965^{* * *}$ & $4.200^{* * *}$ & $4.014^{* * *}$ & $3.484^{* * *}$ & $3.645^{* * *}$ & $3.512^{* * *}$ \\
\hline & $(.163)$ & $(.164)$ & $(.163)$ & $(.129)$ & $(.130)$ & $(.130)$ \\
\hline \multirow[t]{2}{*}{ Modified Z-Score } & $-.917^{* * *}$ & $-.895^{* * *}$ & $-.923^{* * *}$ & $-.430^{* * *}$ & $-.424^{* * *}$ & $-.436^{* * *}$ \\
\hline & $(.053)$ & $(.053)$ & $(.053)$ & $(.033)$ & $(.032)$ & $(.033)$ \\
\hline \multirow[t]{2}{*}{ Return on Assets } & $-6.066^{* * *}$ & $-6.287^{* * *}$ & $-6.094^{* * *}$ & $-9.415^{* * *}$ & $-9.750^{* * *}$ & $-9.357^{* * *}$ \\
\hline & $(.584)$ & $(.581)$ & $(.583)$ & $(.430)$ & $(.434)$ & $(.431)$ \\
\hline Firm Fixed Effects & Yes & Yes & Yes & Yes & Yes & Yes \\
\hline Industry-by-Year Fixed Effects & Yes & No & Yes & Yes & No & Yes \\
\hline State-by-Year Fixed Effects & No & Yes & Yes & No & Yes & Yes \\
\hline Observations & 158,280 & 158,280 & 158,280 & 158,280 & 158,280 & 158,280 \\
\hline Adjusted $R^{2}$ & .602 & .597 & .604 & .666 & .655 & .669 \\
\hline
\end{tabular}




\section{Table 4: Alternative Strategic Action: The Effect of Shadow Union on Cash Holdings}

This table presents the effects of unionization of one firm on the cash holdings of the other, non-unionized firms in the same local labor markets for the sample period 1978 to 2015. Union election data are from the National Labor Relations Board (NLRB) for the period 1977 to 2010. In columns (1) to (3), we use commuting zones to identify local labor markets (LLM) while, in columns (4) to (6), we define local labor markets at the state by industry (SIC two-digit) level. The dependent variable is Cash Holdings, which is defined as the ratio of cash and short-term investments to total assets in percentage. Shadow Union is an indicator variable that equals one if another firm in the same local labor market passes union election during the previous five years, and zero otherwise. Following Bates et al. (2009), we include the determinants of cash holdings. The details of construction of these variables are described in the appendix. We winsorize all unbounded variables at the top and bottom one percent. Numbers in parentheses are standard errors that are clustered by firm. ${ }^{* * *},{ }^{* *}$, and * indicate significance at the $1 \%, 5 \%$, and $10 \%$ levels, respectively.

\begin{tabular}{|c|c|c|c|c|c|c|}
\hline & \multicolumn{6}{|c|}{ Cash Holdings } \\
\hline & \multicolumn{3}{|c|}{ LLM Defined Over Commuting Zone } & \multicolumn{3}{|c|}{ LLM Defined Over State by Industry } \\
\hline & (1) & $(2)$ & $(3)$ & $(4)$ & $(5)$ & $(6)$ \\
\hline Shadow Union & $\begin{array}{c}-.527^{* * *} \\
(.179)\end{array}$ & $\begin{array}{c}-.671^{* * *} \\
(.202)\end{array}$ & $\begin{array}{c}-.739^{* * *} \\
(.203)\end{array}$ & $\begin{array}{c}-.563^{* * *} \\
(.159)\end{array}$ & $\begin{array}{c}-.586^{* * *} \\
(.155)\end{array}$ & $\begin{array}{c}-.590^{* * *} \\
(.161)\end{array}$ \\
\hline Cash Flow & $\begin{array}{c}2.579^{* * *} \\
(.533)\end{array}$ & $\begin{array}{c}2.366^{* * *} \\
(.535)\end{array}$ & $\begin{array}{c}2.613^{* * *} \\
(.534)\end{array}$ & $\begin{array}{c}2.580^{* * *} \\
(.531)\end{array}$ & $\begin{array}{c}2.377^{* * *} \\
(.534)\end{array}$ & $\begin{array}{c}2.617^{* * *} \\
(.532)\end{array}$ \\
\hline Net Working Capital & $\begin{array}{c}-24.261^{* * *} \\
\quad(.666)\end{array}$ & $\begin{array}{c}-24.241^{* * *} \\
(.665)\end{array}$ & $\begin{array}{c}-24.245^{* * *} \\
(.663)\end{array}$ & $\begin{array}{c}-24.361^{* * *} \\
\quad(.662)\end{array}$ & $\begin{array}{c}-24.349^{* * *} \\
(.662)\end{array}$ & $\begin{array}{c}-24.334^{* * *} \\
(.660)\end{array}$ \\
\hline Capital Expenditure & $\begin{array}{c}-27.180^{* * *} \\
(.939)\end{array}$ & $\begin{array}{c}-26.680^{* * *} \\
(.933)\end{array}$ & $\begin{array}{c}-27.385^{* * *} \\
(.946)\end{array}$ & $\begin{array}{c}-27.076^{* * *} \\
(.930)\end{array}$ & $\begin{array}{c}-26.561^{* * *} \\
(.923)\end{array}$ & $\begin{array}{c}-27.260^{* * *} \\
(.936)\end{array}$ \\
\hline Leverage & $\begin{array}{c}-25.958^{* * *} \\
(.608)\end{array}$ & $\begin{array}{c}-26.451^{* * *} \\
(.606)\end{array}$ & $\begin{array}{c}-25.951^{* * *} \\
(.605)\end{array}$ & $\begin{array}{c}-26.014^{* * *} \\
(.605)\end{array}$ & $\begin{array}{c}-26.497^{* * *} \\
(.604)\end{array}$ & $\begin{array}{c}-26.000^{* * *} \\
(.603)\end{array}$ \\
\hline Acquisitions & $\begin{array}{c}-18.611^{* * *} \\
(.647)\end{array}$ & $\begin{array}{c}-18.204^{* * *} \\
(.648)\end{array}$ & $\begin{array}{c}-18.777^{* * *} \\
(.652)\end{array}$ & $\begin{array}{c}-18.630^{* * *} \\
(.647)\end{array}$ & $\begin{array}{c}-18.226^{* * *} \\
(.648)\end{array}$ & $\begin{array}{c}-18.792^{* * *} \\
(.652)\end{array}$ \\
\hline Market-to-Book & $\begin{array}{c}.744^{* * *} \\
(.054)\end{array}$ & $\begin{array}{c}.769^{* * *} \\
(.053)\end{array}$ & $\begin{array}{c}.733^{* * *} \\
(.054)\end{array}$ & $\begin{array}{c}.739^{* * *} \\
(.054)\end{array}$ & $\begin{array}{c}.765^{* * *} \\
(.053)\end{array}$ & $\begin{array}{c}.729^{* * *} \\
(.054)\end{array}$ \\
\hline $\ln ($ Assets $)$ & $\begin{array}{c}-1.968^{* * *} \\
(.123)\end{array}$ & $\begin{array}{c}-1.988^{* * *} \\
(.121)\end{array}$ & $\begin{array}{c}-1.987^{* * *} \\
(.123)\end{array}$ & $\begin{array}{c}-1.975^{* * *} \\
(.123)\end{array}$ & $\begin{array}{c}-1.996^{* * *} \\
(.121)\end{array}$ & $\begin{array}{c}-1.998^{* * *} \\
(.123)\end{array}$ \\
\hline Ind. CF Volatility & (omitted) & $\begin{array}{l}.024 \\
(.031)\end{array}$ & (omitted) & (omitted) & $\begin{array}{l}.023 \\
(.031)\end{array}$ & (omitted) \\
\hline RधD Expenditures & $\begin{array}{c}.531^{* * *} \\
(.089)\end{array}$ & $\begin{array}{c}.529^{* * *} \\
(.086)\end{array}$ & $\begin{array}{c}.521^{* * *} \\
(.089)\end{array}$ & $\begin{array}{c}.531^{* * *} \\
(.089)\end{array}$ & $\begin{array}{c}.529^{* * *} \\
(.086)\end{array}$ & $\begin{array}{c}.521^{* * *} \\
(.089)\end{array}$ \\
\hline Dividend Dummy & $\begin{array}{c}1.241^{* * *} \\
(.210)\end{array}$ & $\begin{array}{c}1.184^{* * *} \\
(.207)\end{array}$ & $\begin{array}{c}1.253^{* * *} \\
(.209)\end{array}$ & $\begin{array}{c}1.225^{* * *} \\
(.208)\end{array}$ & $\begin{array}{c}1.168^{* * *} \\
(.206)\end{array}$ & $\begin{array}{c}1.236^{* * *} \\
(.208)\end{array}$ \\
\hline Firm Fixed Effects & Yes & Yes & Yes & Yes & Yes & Yes \\
\hline Industry-by-Year Fixed Effects & Yes & No & Yes & Yes & No & Yes \\
\hline State-by-Year Fixed Effects & No & Yes & Yes & No & Yes & Yes \\
\hline Observations & 128,530 & 128,530 & 128,530 & 130,340 & 130,340 & 130,340 \\
\hline Adjusted $R^{2}$ & .747 & .744 & .747 & .746 & .744 & .746 \\
\hline
\end{tabular}




\section{Table 5: Robustness Tests}

These tables report additional robustness tests of results documented in Panel A of Table 3 in the sample period 1978 to 2015. Panel A reports the empirical distribution of the coefficients on Pseudo Shadow Union based on estimating Equation (2) 1,000 times using the bootstrapped sample. We randomly assign a firm's local labor market (a commuting zone where its headquarters is located) by maintaining a cross-sectional distribution of firms in local labor markets and a panel structure of successful union elections. Pseudo Shadow Union is an indicator variable that equals one if another firm in the same pseudo local labor market passes union election during the previous five years, and zero otherwise. The actual coefficients from columns (3) and (6) in Panel A of Table 3 are reported in the first column for ease of comparison. Panels B1 and B2 repeat the test for Panel A of Table 3 using three and seven year horizons, respectively, for the shadow union effect. Specifically, Shadow Union ${ }^{3 Y R(7 Y R)}$ is an indicator variable that equals one if another firm in the same local labor market passes union election during the previous three (seven) years, and zero otherwise. Panel $\mathrm{C}$ reports the results using alternative measures of financial leverage: Alternative Book Leverage, defined as the total debt divided by the book value of total assets, and Alternative Market Leverage, defined as the total debt divided by the market value of assets. We winsorize all unbounded variables at the top and bottom one percent. The details of construction of all variables are described in the appendix. Numbers in parentheses are standard errors that are clustered by firm. ***, **, and $*$ indicate significance at the $1 \%, 5 \%$, and $10 \%$ levels, respectively.

Panel A. Placebo Tests: Regression Coefficients from Bootstrapped Sample

\begin{tabular}{|c|c|c|c|c|c|c|c|c|c|c|c|}
\hline \multirow[b]{2}{*}{ Dep. Var. } & \multirow{2}{*}{$\begin{array}{c}\text { Cols. (3), (6) } \\
\text { Panel A of Table } 3\end{array}$} & \multicolumn{10}{|c|}{ Regression Coefficients on Pseudo Shadow Union } \\
\hline & & Mean & p1 & $\mathrm{p} 5$ & p10 & p25 & $\mathrm{p} 50$ & $\mathrm{p} 75$ & p90 & p95 & p99 \\
\hline Book Leverage & 1.162 & .009 & -.726 & -.539 & -.421 & -.187 & .018 & .215 & .397 & .515 & .759 \\
\hline Market Leverage & 1.249 & -.010 & -.645 & -.459 & -.358 & -.179 & -.002 & .169 & .301 & .379 & .572 \\
\hline \multicolumn{6}{|c|}{ Firm-level Controls } & \multicolumn{6}{|l|}{ Yes } \\
\hline \multicolumn{6}{|l|}{ Firm Fixed Effects } & \multicolumn{6}{|l|}{ Yes } \\
\hline \multicolumn{6}{|c|}{ Industry-by-Year Fixed Effects } & \multicolumn{6}{|l|}{ Yes } \\
\hline \multicolumn{6}{|c|}{ State-by-Year Fixed Effects } & \multicolumn{6}{|l|}{ Yes } \\
\hline
\end{tabular}

Panel B1. Using Alternative Horizons: 3 Years

\begin{tabular}{|c|c|c|c|c|c|c|}
\hline & \multicolumn{3}{|c|}{ Book Leverage } & \multicolumn{3}{|c|}{ Market Leverage } \\
\hline & (1) & $(2)$ & $(3)$ & $(4)$ & $(5)$ & $(6)$ \\
\hline Shadow Union ${ }^{3 Y R}$ & $\begin{array}{c}.674^{* * *} \\
(.204)\end{array}$ & $\begin{array}{c}.867^{* * *} \\
(.236)\end{array}$ & $\begin{array}{c}.896^{* * *} \\
(.233)\end{array}$ & $\begin{array}{c}.639^{* * *} \\
(.178)\end{array}$ & $\begin{array}{c}.807^{* * *} \\
(.207)\end{array}$ & $\begin{array}{c}.835^{* * *} \\
(.203)\end{array}$ \\
\hline Firm-level Controls & Yes & Yes & Yes & Yes & Yes & Yes \\
\hline Firm Fixed Effects & Yes & Yes & Yes & Yes & Yes & Yes \\
\hline Industry-by-Year Fixed Effects & Yes & No & Yes & Yes & No & Yes \\
\hline State-by-Year Fixed Effects & No & Yes & Yes & No & Yes & Yes \\
\hline Observations & 150,057 & 150,057 & 150,057 & 150,057 & 150,057 & 150,057 \\
\hline Adjusted $R^{2}$ & .603 & .597 & .605 & .663 & .652 & .665 \\
\hline
\end{tabular}




\section{Table 5: Robustness Tests (continued)}

Panel B2. Using Alternative Horizons: 7 Years

\begin{tabular}{|c|c|c|c|c|c|c|}
\hline & \multicolumn{3}{|c|}{ Book Leverage } & \multicolumn{3}{|c|}{ Market Leverage } \\
\hline & $(1)$ & $(2)$ & $(3)$ & $(4)$ & $(5)$ & $(6)$ \\
\hline Shadow Union ${ }^{7 Y R}$ & $\begin{array}{c}.851^{* * *} \\
(.315)\end{array}$ & $\begin{array}{c}1.004^{* * *} \\
(.353)\end{array}$ & $\begin{array}{c}1.104^{* * *} \\
(.346)\end{array}$ & $\begin{array}{c}1.113^{* * *} \\
(.264)\end{array}$ & $\begin{array}{c}1.437^{* * *} \\
(.300)\end{array}$ & $\begin{array}{c}1.437^{* * *} \\
(.292)\end{array}$ \\
\hline Firm-level Controls & Yes & Yes & Yes & Yes & Yes & Yes \\
\hline Firm Fixed Effects & Yes & Yes & Yes & Yes & Yes & Yes \\
\hline Industry-by-Year Fixed Effects & Yes & No & Yes & Yes & No & Yes \\
\hline State-by-Year Fixed Effects & No & Yes & Yes & No & Yes & Yes \\
\hline Observations & 156,250 & 156,250 & 156,250 & 156,250 & 156,250 & 156,250 \\
\hline Adjusted $R^{2}$ & .600 & .594 & .602 & .662 & .651 & .664 \\
\hline & \multicolumn{3}{|c|}{ Alternative Book Leverage } & \multicolumn{3}{|c|}{ Alternative Market Leverage } \\
\hline & $(1)$ & $(2)$ & $(3)$ & $(4)$ & $(5)$ & $(6)$ \\
\hline Shadow Union & $\begin{array}{c}.621^{* * *} \\
(.203)\end{array}$ & $\begin{array}{c}.765^{* * *} \\
(.231)\end{array}$ & $\begin{array}{c}.828^{* * *} \\
(.226)\end{array}$ & $\begin{array}{c}.663^{* * *} \\
(.177)\end{array}$ & $\begin{array}{c}.964^{* * *} \\
(.204)\end{array}$ & $\begin{array}{c}.951^{* * *} \\
(.199)\end{array}$ \\
\hline Firm-level Controls & Yes & Yes & Yes & Yes & Yes & Yes \\
\hline Firm Fixed Effects & Yes & Yes & Yes & Yes & Yes & Yes \\
\hline Industry-by-Year Fixed Effects & Yes & No & Yes & Yes & No & Yes \\
\hline State-by-Year Fixed Effects & No & Yes & Yes & No & Yes & Yes \\
\hline Observations & 156,247 & 156,247 & 156,247 & 156,250 & 156,250 & 156,250 \\
\hline Adjusted $R^{2}$ & .626 & .622 & .629 & .670 & .660 & .672 \\
\hline
\end{tabular}




\section{Table 6: Heightened Threat of New Unionization in Local Labor Markets: Marginal Increase in Probability of Unionization}

Columns (1) and (2) repeat the test in Panel A of Table 3 by conditioning Shadow Union on dummy variables indicating firms with high and low annual median wages. We use industry-level annual median wage data from the Occupational Employment Statistics (OES) Survey by the Bureau of Labor Statistics. Specifically, we define High (Low) Median Wage as an indicator variable that equals one if the time-series average of industry-level annual median wages of is above (below) the median of the distribution, zero otherwise. Shadow Union is an indicator variable that equals one if another firm in the same local labor market passes union election during the previous five years, and zero otherwise. High Median Wage is absorbed by the firm fixed effects. Columns (3) and (4) repeat the test in Panel A of Table 3 by reconstructing Shadow Union based on the salience of successful election events. We define Shadow Union ${ }^{\text {Multi (Single) as an }}$ indicator variable that equals one if other firms in the same local labor market pass multiple (single) union elections during the previous five years, and zero otherwise. The coefficient comparisons at the bottom of the table are based on one-tailed tests with p-values in square brackets. We winsorize all unbounded variables at the top and bottom one percent. The details of construction of all variables are described in the appendix. Numbers in parentheses are standard errors that are clustered by firm. ${ }^{* * *},{ }^{* *}$, and $*$ indicate significance at the $1 \%, 5 \%$, and $10 \%$ levels, respectively.

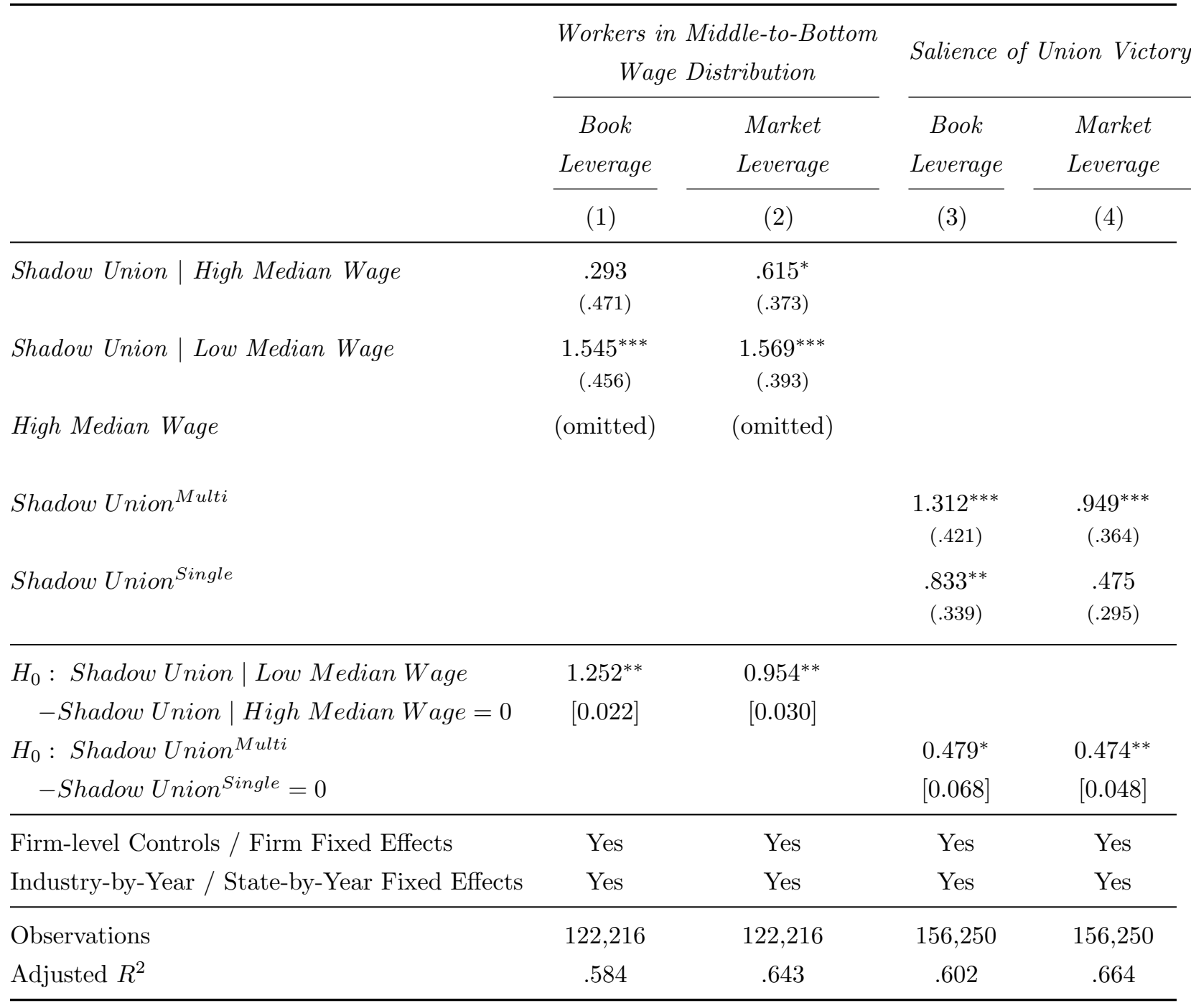




\section{Table 7: Heightened Threat of New Unionization in Local Labor Markets: Union Rents}

This table repeats the test in Panel A of Table 3 by conditioning Shadow Union on dummy variables indicating high and low union rents. We use three factors that indicate high union rents: high labor intensity (columns (1) and (2)), low unemployment rates (columns (3) and (4)), and low product market competition (columns (5) and (6)). Shadow Union is an indicator variable that equals one if another firm in the same local labor market passes union election during the previous five years, and zero otherwise. High (Low) Union Rent is an indicator variable that equals one if a firm faces high (low) union rents, and zero otherwise. High Union Rents in columns (3) and (4) is absorbed by the state-by-year fixed effects. The coefficient comparisons at the bottom of the table are based on one-tailed tests with p-values in square brackets. We winsorize all unbounded variables at the top and bottom one percent. The details of construction of all variables are described in the appendix. Numbers in parentheses are standard errors that are clustered by firm. $* * *, * *$, and $*$ indicate significance at the $1 \%, 5 \%$, and $10 \%$ levels, respectively.

\begin{tabular}{|c|c|c|c|c|c|c|}
\hline & \multicolumn{2}{|c|}{$\begin{array}{c}\text { Labor } \\
\text { Intensity }\end{array}$} & \multicolumn{2}{|c|}{$\begin{array}{c}\text { Unemployment } \\
\text { Rates }\end{array}$} & \multicolumn{2}{|c|}{$\begin{array}{c}\text { Product Market } \\
\text { Competition }\end{array}$} \\
\hline & Book & Market & Book & Market & Book & Market \\
\hline & Leverage & Leverage & Leverage & Leverage & Leverage & Leverage \\
\hline & $(1)$ & $(2)$ & $(3)$ & $(4)$ & $(5)$ & $(6)$ \\
\hline Shadow Union | High Union Rents & $\begin{array}{c}1.832^{* * *} \\
(.448)\end{array}$ & $\begin{array}{c}1.453^{* * *} \\
(.371)\end{array}$ & $\begin{array}{c}1.506^{* * *} \\
(.365)\end{array}$ & $\begin{array}{c}1.380^{* * *} \\
(.322)\end{array}$ & $\begin{array}{c}2.991^{* * *} \\
(.777)\end{array}$ & $\begin{array}{c}1.718^{* * *} \\
(.663)\end{array}$ \\
\hline Shadow Union | Low Union Rents & $\begin{array}{l}.702^{*} \\
(.387)\end{array}$ & $\begin{array}{c}1.035^{* * *} \\
(.342)\end{array}$ & $\begin{array}{l}.604 \\
(.441)\end{array}$ & $\begin{array}{l}.720^{*} \\
(.377)\end{array}$ & $\begin{array}{l}.600 \\
(.656)\end{array}$ & $\begin{array}{l}.757 \\
(.575)\end{array}$ \\
\hline High Union Rents & $\begin{array}{c}-1.569^{* * *} \\
(.551)\end{array}$ & $\begin{array}{l}-.576 \\
(.463)\end{array}$ & (omitted) & (omitted) & $\begin{array}{c}1.805^{* *} \\
(.771)\end{array}$ & $\begin{array}{l}.887 \\
(.647)\end{array}$ \\
\hline$H_{0}:$ Shadow Union $\mid$ High Rents & $1.130^{* *}$ & 0.418 & $0.902^{* *}$ & $0.660^{*}$ & $2.391^{* * *}$ & $0.961^{*}$ \\
\hline- Shadow Union $\mid$ Low Rents $=0$ & {$[0.014]$} & {$[0.167]$} & {$[0.030]$} & {$[0.058]$} & {$[0.001]$} & {$[0.075]$} \\
\hline Firm-level Controls & Yes & Yes & Yes & Yes & Yes & Yes \\
\hline Firm Fixed Effects & Yes & Yes & Yes & Yes & Yes & Yes \\
\hline Industry-by-Year Fixed Effects & Yes & Yes & Yes & Yes & Yes & Yes \\
\hline State-by-Year Fixed Effects & Yes & Yes & Yes & Yes & Yes & Yes \\
\hline Observations & 140,536 & 147,187 & 140,536 & 147,187 & 48,886 & 48,886 \\
\hline Adjusted $R^{2}$ & .616 & .614 & .676 & .672 & .611 & .676 \\
\hline
\end{tabular}




\section{Table 8: Is the Threat Credible?}

Panel A examines the effects of shadow unions on the average wages in local labor markets for the sample period 1994 to 2015 . The dependent variable is $\ln$ (Average Wages), defined as the log of average monthly earnings (inflation adjusted) of employees with stable jobs in local labor markets over a quarter. The wage data come from the Quarterly Workforce Indicators (QWI). In columns (1) and (2), we identify local labor market using commuting zones. In columns (3) and (4) we define local labor market at the state by industry (NAICS sector) level since the QWI uses the 2012 NAICS codes for industry classification. Shadow Union is an indicator variable that equals one if a firm in a local labor market passes union election during the previous five years, and zero otherwise. We include a set of commuting zone-, state-, and industry-level time-varying control variables. These control variables are lagged by one year or quarter depending on the data availability. We winsorize all unbounded variables at the top and bottom one percent. The details of construction of all variables are described in the appendix. Numbers in parentheses are standard errors that are clustered at the local labor market level. ${ }^{* * *},{ }^{* *}$, and ${ }^{*}$ indicate significance at the $1 \%, 5 \%$, and $10 \%$ levels, respectively.

Panel A. Wages in Local Labor Markets

\begin{tabular}{|c|c|c|c|c|}
\hline & \multicolumn{4}{|c|}{ ln(Average Wages) $(\times 100)$} \\
\hline & \multicolumn{2}{|c|}{ LLM Defined Over Commuting Zone } & \multicolumn{2}{|c|}{ LLM Defined Over State by Industry } \\
\hline & $(1)$ & $(2)$ & $(3)$ & $(4)$ \\
\hline Shadow Union & $\begin{array}{c}1.375^{* * *} \\
(.329)\end{array}$ & $\begin{array}{c}.909^{* * *} \\
(.304)\end{array}$ & $\begin{array}{c}.625^{* *} \\
(.297)\end{array}$ & $\begin{array}{c}.586^{* *} \\
(.295)\end{array}$ \\
\hline Unemployment Rates & & $\begin{array}{c}-156.772^{* * *} \\
(18.968)\end{array}$ & $\begin{array}{c}-101.576^{* * *} \\
(13.387)\end{array}$ & $\begin{array}{c}-99.897^{* * *} \\
(13.346)\end{array}$ \\
\hline $\ln$ (Population) & & $\begin{array}{r}-4.129 \\
(3.856)\end{array}$ & $\begin{array}{c}-10.581 \\
(8.157)\end{array}$ & $\begin{array}{c}-11.348 \\
(8.098)\end{array}$ \\
\hline GDP Growth & & & $\begin{array}{c}14.326^{* * *} \\
(3.652)\end{array}$ & $\begin{array}{c}14.270^{* * *} \\
(3.613)\end{array}$ \\
\hline Industry Output Growth & & & $\begin{array}{l}.790 \\
(.817)\end{array}$ & $\begin{array}{l}.681 \\
(.816)\end{array}$ \\
\hline Leading Index & & & $\begin{array}{l}.042 \\
(.053)\end{array}$ & $\begin{array}{l}.047 \\
(.052)\end{array}$ \\
\hline Home Ownership & & & $\begin{array}{l}-1.882 \\
(6.444)\end{array}$ & $\begin{array}{c}-3.108 \\
(6.475)\end{array}$ \\
\hline $\ln$ (\# of Comm. Banks) & & & $\begin{array}{c}.339 \\
(1.102)\end{array}$ & $\begin{array}{c}.413 \\
(1.099)\end{array}$ \\
\hline $\ln ($ Housing Price Growth) & & & $\begin{array}{l}2.884 \\
(3.058)\end{array}$ & $\begin{array}{l}3.408 \\
(3.065)\end{array}$ \\
\hline ln(Population Density) & & & $\begin{array}{c}13.927^{*} \\
(7.878)\end{array}$ & $\begin{array}{c}14.059^{*} \\
(7.821)\end{array}$ \\
\hline Educational Attainment & & & & $\begin{array}{l}.003 \\
(.065)\end{array}$ \\
\hline Industry Union Coverage & & & & $\begin{array}{c}51.193^{* * *} \\
(11.558)\end{array}$ \\
\hline State Union Coverage & & & & $\begin{array}{c}14.583^{*} \\
(7.618)\end{array}$ \\
\hline LLM Fixed Effects & Yes & Yes & Yes & Yes \\
\hline Year-Quarter Fixed Effects & Yes & Yes & Yes & Yes \\
\hline Observations & 56,017 & 56,017 & 68,671 & 68,671 \\
\hline Adjusted $R^{2}$ & .882 & .890 & .967 & .967 \\
\hline
\end{tabular}




\section{Table 8: Is the Threat Credible? (continued)}

Panels B1 and B2 examine the effect of shadow unions on the likelihood of subsequent successful union elections in local labor markets. We use commuting zone (state by industry - two-digit SIC) to define local labor markets in Panel B1 (B2). The dependent variable is an indicator that equals one if there is at least one successful union election in a local labor market at year $t$, zero otherwise. In columns (1) and (2), we apply the one-step first-difference generalized method of moments (GMM) estimation, proposed by Arellano and Bond (1991). In columns (3) and (4), we use two-step system GMM estimation of Blundell and Bond (1998). AR1(2) indicates a test for the first-(second-)order serial correlation in the first-differenced residuals. In column (2), we include Unemployment Rates and $\ln$ (Population); in column (4), we additionally include GDP Growth, Industry Output Growth, Leading Index, Home Ownership, In(Population Density), and Industry (State) Union Coverage. These control variables are lagged by one year. We winsorize all unbounded variables at the top and bottom one percent. The details of construction of all variables are described in the appendix. Numbers in parentheses are standard errors that are robust to heteroskedasiticy and autocorrelation within local labor markets. In columns (3) and (4), the standard errors are Windmeijercorrected (Windmeijer, 2005). ${ }^{* * *}, * *$, and $*$ indicate significance at the $1 \%, 5 \%$, and $10 \%$ levels, respectively.

Panel B1. Likelihood of Successful Elections in Local Labor Markets: Commuting Zone

\begin{tabular}{|c|c|c|c|c|}
\hline & \multicolumn{4}{|c|}{$\mathbb{1}_{\{\exists \text { Union Victory at } t\}}$} \\
\hline & \multicolumn{2}{|c|}{ Dynamic Model: Arellano/Bond } & \multicolumn{2}{|c|}{ Dynamic Model: Blundell/Bond } \\
\hline & (1) & $(2)$ & (3) & $(4)$ \\
\hline $\mathbb{1}_{\{\exists \text { Union Victory at } t-1\}}$ & $\begin{array}{c}.046^{* * *} \\
(.012)\end{array}$ & $\begin{array}{c}.045^{* * *} \\
(.016)\end{array}$ & $\begin{array}{c}.095^{* * *} \\
(.014)\end{array}$ & $\begin{array}{c}.093^{* * *} \\
(.016)\end{array}$ \\
\hline Controls & No & Yes & No & Yes \\
\hline LLM / Year Fixed Effects & Yes & Yes & Yes & Yes \\
\hline Observations & 23,712 & 14,079 & 24,453 & 14,820 \\
\hline Wald Chi-squared & $146.207^{* * *}$ & $85.183^{* * *}$ & $174.371^{* * *}$ & $429.102^{* * *}$ \\
\hline AR1 (p-value) & 0.000 & 0.000 & 0.000 & 0.000 \\
\hline AR2 (p-value) & .956 & .379 & .133 & .750 \\
\hline \multicolumn{5}{|c|}{ Panel B2. Likelihood of Successful Elections in Local Labor Markets: State by Industry } \\
\hline & \multicolumn{4}{|c|}{$\mathbb{1}_{\{\exists \text { Union Victory at } t\}}$} \\
\hline & \multicolumn{2}{|c|}{ Dynamic Model: Arellano/Bond } & \multicolumn{2}{|c|}{ Dynamic Model: Blundell/Bond } \\
\hline & (1) & $(2)$ & (3) & (4) \\
\hline $\mathbb{1}_{\{\exists \text { Union Victory at } t-1\}}$ & $\begin{array}{c}.049^{* * *} \\
(.009)\end{array}$ & $\begin{array}{c}.038^{* * *} \\
(.010)\end{array}$ & $\begin{array}{c}.052^{* * *} \\
(.007)\end{array}$ & $\begin{array}{c}.051^{* * *} \\
(.010)\end{array}$ \\
\hline Controls & No & Yes & No & Yes \\
\hline LLM / Year Fixed Effects & Yes & Yes & Yes & Yes \\
\hline Observations & 113,632 & 66,500 & 117,183 & 69,300 \\
\hline Wald Chi-squared & $217.102^{* * *}$ & $2,548.909^{* * *}$ & $219.757^{* * *}$ & $180.734^{* * *}$ \\
\hline AR1 (p-value) & 0.000 & 0.000 & 0.000 & 0.000 \\
\hline AR2 (p-value) & .375 & .935 & .354 & .670 \\
\hline
\end{tabular}




\section{Internet Appendix to "Shadow Union in Local Labor Markets and Capital Structure"}

\section{A. Economic Significance of Determinants of Financial Leverage}

In this section, we estimate and compare the economic significance of other determinants of financial leverage and that of shadow union effects. Our calculations are based on the coefficient estimates reported in columns (3) and (6) in Panel A of Table 3 in the main text. Since we estimate these coefficients by exploiting within-firm variations in leverage ratios and explanatory variables, we use a within-firm, one-standard-deviation change in each determinant to gauge its impact on market leverage.

\section{[Insert Table IA.1 here.]}

Panel A of Table IA.1 reports within-firm standard deviation of each determinant and its associated change in book leverage when we define local labor markets based on the commuting zones. For example, a one-standard-deviation change in Tangibility, Market-to-Book, $\ln ($ sales), Modified Z-Score, and Return on Assets is associated with a change in Book Leverage of 2.11, $1.17,2.87,2.17$, and 0.96 percentage points in absolute value, respectively. In comparison, a typical shadow union in the sample leads non-union firms in the same local labor market to increase their leverage by 1.16 percentage points. It is important to note that we cannot draw a causal inference from these calculations for firm characteristics whereas the shadow union effect could have a causal interpretation as discussed in the main text. In Panel B, we repeat this exercise based on the coefficient estimates in column (6) in Panel A of Table 3 in the main text. Similarly, a one-standard-deviation change in Tangibility, Market-to-Book, $\ln ($ sales), Modified ZScore, and Return on Assets is related to a change in Market Leverage of 1.75, 2.67, 2.51, 1.02, and 1.48 percentage points in absolute value, respectively. After a union victory, non-union firms in the same commuting zone increase their market leverage by 1.25 percentage points. These comparisons suggest that the shadow union effect on leverage is economically significant and comparable to the changes in leverage that are associated with a change in other firm-level determinants of financial leverage.

\section{B. Excluding States that Passed Right-to-Work (RTW) Legislation}

Several states in the U.S. have passed the right-to-work (RTW) legislation over our sample period. Our sample covers the period from 1978 to 2015 and includes the passage of RTW laws in Texas (1993; revised), Idaho (1985), Oklahoma (2001), Indiana (2012), and Michigan (2012). ${ }^{1}$ Since the passage of these laws may weaken union bargaining power, which might lead firms under these laws to lower their leverage ratio (Matsa, 2010), it may complicate the interpretation of our main findings. In addition, to the extent that the passage of the RTW legislation may affect the probability of union victory or union organizing activities in those states, we exclude those states that have passed a RTW law and re-estimate our main specification to avoid such a complication.

\footnotetext{
${ }^{1}$ Wisconsin adopted a RTW law in 2015 which is the last year of our sample. Further excluding Wisconsin in our sample does not alter our main findings.
} 
[Insert Table IA.2 here.]

Table IA.2 reports the results of this exercise. The coefficient estimates are all statistically significant at the $1 \%$ level and similar in magnitude to those estimated from the full sample. This indicates that the passage of RTW laws does not affect the shadow union effect on financial leverage.

\section{Additional Robustness Tests for the Effect of Shadow Union on Financial Leverage}

In this section, we present additional robustness tests for the effect of shadow union on financial leverage. In Panel A of Table IA.3, we consider an alternative definition of local labor markets to examine the robustness of our main results. We define local labor markets based on the 179 economic areas by 67 industries (SIC two-digit) and re-estimate our baseline specification in Table 3 in the main text. The economic areas are created by the Bureau of Economic Analysis (BEA) and the 3,141 US counties are grouped into such areas, based on the commuting data (see Johnson and Kort (2004) for detailed information on the construction of economic areas). We obtain similar results as in Table 3 of the main text although not all of these estimates are precisely estimated because this alternative definition is too fine to reliably estimate shadow union effect: economic areas $\times$ SIC two-digit $=179 \times 67=11,993$ local labor markets.

[Insert Panel A of Table IA.3 here.]

It is possible that the control variables used in the regressions of Table 3 in the main text are also affected by the shadow union. To avoid potential concerns regarding bad and/or endogenous controls, we repeats the tests in Panel A of Table 3 of the main text by excluding the firm-level controls. We obtain robust results (Panel B of Table IA.3): the estimated coefficients on Shadow Union are all statistically significant at the $1 \%$ level and they are larger in magnitude compared to those obtained with control variables. We also re-estimate our baseline specification with one-year lagged control variables and obtain similar results (Panel C of Table IA.3).

[Insert Panels B and C of Table IA.3 here.]

\section{Coefficients on Control Variables}

In Tables 5, 6, and 7 of the main text, we do not report the coefficients on control variables for brevity. In Panels A1, A2, and B of Table IA.4, we document Panels B1, B2, and C of Table 5 in the main text with all the coefficients on control variables.

[Insert Table IA.4 here.]

We also report all the coefficients on control variables that are omitted from Tables 6 and 7 of the main text in Tables IA.5 and IA.6, respectively.

[Insert Tables IA.5 and IA.6 here.] 


\section{REFERENCES}

Johnson, Kenneth P and John R Kort, "2004 Redefinition of the BEA Economic Areas," Survey of Current Business, 2004, 84 (11), 68-75.

Matsa, David A., "Capital Structure as a Strategic Variable: Evidence from Collective Bargaining," Journal of Finance, 2010, 65 (3), 1197-1232. 


\section{Table IA.1: Economic Significance of Determinants of Financial Leverage}

These tables report and compare the economic significance of various determinants of book and market leverage ratios and that of shadow union effects documented in Table 3 of the main text in which we define local labor markets over commuting zones. Panels A and B are based on the regression estimates in columns (3) and (6), Panel A of Table 3 of the main text, respectively. Since the coefficients estimates rely on the within-firm variation, we use a within-firm one-standard-deviation change in each of determinant to compare the economic significance. Each of change in leverage ratios is calculated by multiplying corresponding estimated coefficient by a within-firm one-standard-deviation. Book Leverage is the debt-to-capital ratio, defined as the total debt divided by the sum of total debt and book value of equity. The total debt is the sum of long-term debt and debt in current liabilities. Market leverage is the ratio of total debt to the sum of total debt and market value of equity. Shadow Union is an indicator variable equal to one if another firm in the same local labor market passes union election during the previous five years, and zero otherwise. The details of construction of all other variables are described in the appendix.

\section{Panel A. Local Labor Markets Defined Over Commuting Zone: Book Leverage}

\begin{tabular}{lcc} 
Determinant & Within-Firm Std.Dev. & Change in Book Leverage \\
\hline Tangibility & 0.092 & $2.11 \%$ \\
Market-to-Book & 1.664 & $-1.17 \%$ \\
ln(Sales) & 0.720 & $2.87 \%$ \\
Modified Z-Score & 2.360 & $-2.17 \%$ \\
Return on Assets & 0.158 & $-0.96 \%$ \\
Shadow Union & - & $1.16 \%$
\end{tabular}

Panel B. Local Labor Markets Defined Over Commuting Zone: Market Leverage

\begin{tabular}{lcc} 
Determinant & Within-Firm Std.Dev. & Change in Market Leverage \\
\hline Tangibility & 0.092 & $1.75 \%$ \\
Market-to-Book & 1.664 & $-2.67 \%$ \\
ln(Sales) & 0.720 & $2.51 \%$ \\
Modified Z-Score & 2.360 & $-1.02 \%$ \\
Return on Assets & 0.158 & $-1.48 \%$ \\
Shadow Union & - & $1.25 \%$
\end{tabular}




\section{Table IA.2: Effect of Shadow Union on Financial Leverage: Excluding States that Passed Right-to-Work Laws over Sample Period}

This table repeats the test in Panel A of Table 3 in the main text by excluding states that have passed right-to-work (RTW) legislation over the sample period 1978 to 2015. The excluded states are Texas (1993; revised), Idaho (1985), Oklahoma (2001), Indiana (2012), and Michigan (2012). In columns (1) to (3), the dependent variable is Book Leverage, while in columns (4) to (6) the dependent variable is Market Leverage. Book Leverage is the debt-to-capital ratio, defined as the total debt divided by the sum of total debt and book value of equity. The total debt is the sum of long-term debt and debt in current liabilities. Market leverage is the ratio of total debt to the sum of total debt and market value of equity. Shadow Union is an indicator variable equal to one if another firm in the same local labor market passes union election during the previous five years, and zero otherwise. We winsorize all unbounded variables at the top and bottom one percent. The details of construction of all other variables are described in the appendix. Numbers in parentheses are standard errors that are clustered by firm. ${ }^{* *}, * *$, and $*$ indicate significance at the $1 \%, 5 \%$, and $10 \%$ levels, respectively.

\begin{tabular}{|c|c|c|c|c|c|c|}
\hline & \multicolumn{3}{|c|}{ Book Leverage } & \multicolumn{3}{|c|}{ Market Leverage } \\
\hline & (1) & $(2)$ & $(3)$ & (4) & $(5)$ & $(6)$ \\
\hline Shadow Union & $\begin{array}{c}.817^{\text {*** }} \\
(.299)\end{array}$ & $\begin{array}{c}1.113^{\text {*** }} \\
(.347)\end{array}$ & $\begin{array}{c}1.261^{* * *} \\
(.338)\end{array}$ & $\begin{array}{c}.839^{* * *} \\
(.259)\end{array}$ & $\begin{array}{c}1.233^{\text {*** }} \\
(.300)\end{array}$ & $\begin{array}{c}1.301^{\text {*** }} \\
(.292)\end{array}$ \\
\hline Tangibility & $\begin{array}{c}22.939^{* * *} \\
\quad(1.157)\end{array}$ & $\begin{array}{c}23.248^{* * *} \\
(1.176)\end{array}$ & $\begin{array}{c}22.909^{* * *} \\
(1.150)\end{array}$ & $\begin{array}{c}18.690^{* * *} \\
(.968)\end{array}$ & $\begin{array}{c}20.134^{* * *} \\
(.999)\end{array}$ & $\begin{array}{c}18.609^{* * *} \\
(.966)\end{array}$ \\
\hline Market-to-Book & $\begin{array}{c}-.686^{* * *} \\
(.045)\end{array}$ & $\begin{array}{c}-.716^{* * *} \\
(.045)\end{array}$ & $\begin{array}{c}-.698^{* * *} \\
(.045)\end{array}$ & $\begin{array}{c}-1.509^{* * *} \\
(.044)\end{array}$ & $\begin{array}{c}-1.572^{* * *} \\
(.046)\end{array}$ & $\begin{array}{c}-1.503^{* * *} \\
(.044)\end{array}$ \\
\hline $\ln ($ Sales $)$ & $\begin{array}{c}3.744^{* * *} \\
(.176)\end{array}$ & $\begin{array}{c}4.045^{* * *} \\
(.179)\end{array}$ & $\begin{array}{c}3.799^{* * *} \\
(.176)\end{array}$ & $\begin{array}{c}3.268^{* * *} \\
(.139)\end{array}$ & $\begin{array}{c}3.500^{* * *} \\
(.143)\end{array}$ & $\begin{array}{c}3.290^{* * *} \\
(.140)\end{array}$ \\
\hline Modified Z-Score & $\begin{array}{c}-.867^{* * *} \\
(.054)\end{array}$ & $\begin{array}{c}-.848^{* * *} \\
(.054)\end{array}$ & $\begin{array}{c}-.869^{* * *} \\
(.054)\end{array}$ & $\begin{array}{c}-.400^{* * *} \\
(.033)\end{array}$ & $\begin{array}{c}-.392^{* * *} \\
(.033)\end{array}$ & $\begin{array}{c}-.402^{* * *} \\
(.033)\end{array}$ \\
\hline Return on Assets & $\begin{array}{c}-5.803^{* * *} \\
(.614)\end{array}$ & $\begin{array}{c}-6.014^{* * *} \\
(.611)\end{array}$ & $\begin{array}{c}-5.866^{* * *} \\
(.613)\end{array}$ & $\begin{array}{c}-8.671^{* * *} \\
(.442)\end{array}$ & $\begin{array}{c}-9.024^{* * *} \\
(.446)\end{array}$ & $\begin{array}{c}-8.657^{* * *} \\
(.443)\end{array}$ \\
\hline Firm-level Controls & Yes & Yes & Yes & Yes & Yes & Yes \\
\hline Firm Fixed Effects & Yes & Yes & Yes & Yes & Yes & Yes \\
\hline Industry-by-Year Fixed Effects & Yes & No & Yes & Yes & No & Yes \\
\hline State-by-Year Fixed Effects & No & Yes & Yes & No & Yes & Yes \\
\hline Observations & 133,339 & 133,339 & 133,339 & 133,339 & 133,339 & 133,339 \\
\hline Adjusted $R^{2}$ & .604 & .598 & .606 & .670 & .658 & .672 \\
\hline
\end{tabular}




\section{Table IA.3: Additional Robustness Tests for the Effect of Shadow Union on Financial Leverage}

Panel A repeats the tests in Panel A of Table 3 in the main text using an alternative definition of local labor markets at the BEA (Bureau of Economic Analysis) Economic Area by industry (SIC two-digit) level. In columns (1) to (3), the dependent variable is Book Leverage, while in columns (4) to (6) the dependent variable is Market Leverage. Book Leverage is the debt-to-capital ratio, defined as the total debt divided by the sum of total debt and book value of equity. The total debt is the sum of long-term debt and debt in current liabilities. Market leverage is the ratio of total debt to the sum of total debt and market value of equity. Shadow Union is an indicator variable equal to one if another firm in the same local labor market passes union election during the previous five years, and zero otherwise. We winsorize all unbounded variables at the top and bottom one percent. The details of construction of all other variables are described in the appendix. Numbers in parentheses are standard errors that are clustered by firm. ${ }^{* * *}, * *$, and * indicate significance at the $1 \%, 5 \%$, and $10 \%$ levels, respectively.

\section{Panel A. Local Labor Markets Defined Over BEA Economic Area by Industry}

\begin{tabular}{|c|c|c|c|c|c|c|}
\hline & \multicolumn{3}{|c|}{ Book Leverage } & \multicolumn{3}{|c|}{ Market Leverage } \\
\hline & (1) & $(2)$ & $(3)$ & $(4)$ & $(5)$ & $(6)$ \\
\hline \multirow[t]{2}{*}{ Shadow Union } & .171 & .382 & .263 & $.546^{* *}$ & $.806^{* * *}$ & $.625^{* *}$ \\
\hline & $(.280)$ & $(.290)$ & $(.292)$ & $(.246)$ & $(.253)$ & $(.256)$ \\
\hline \multirow[t]{2}{*}{ Tangibility } & $22.833^{* * *}$ & $23.142^{* * *}$ & $22.810^{* * *}$ & $19.054^{* * *}$ & $20.354^{* * *}$ & $18.895^{* * *}$ \\
\hline & $(1.045)$ & $(1.069)$ & $(1.059)$ & $(.870)$ & $(.897)$ & $(.876)$ \\
\hline \multirow[t]{2}{*}{ Market-to-Book } & $-.693^{* * *}$ & $-.714^{* * *}$ & $-.687^{* * *}$ & $-1.609^{* * *}$ & $-1.664^{* * *}$ & $-1.589^{* * *}$ \\
\hline & $(.044)$ & $(.044)$ & $(.044)$ & $(.044)$ & $(.046)$ & $(.044)$ \\
\hline \multirow[t]{2}{*}{$\ln$ (Sales) } & $3.948^{* * *}$ & $4.248^{* * *}$ & $4.052^{* * *}$ & $3.473^{* * *}$ & $3.690^{* * *}$ & $3.544^{* * *}$ \\
\hline & $(.163)$ & $(.164)$ & $(.165)$ & $(.129)$ & $(.130)$ & $(.130)$ \\
\hline \multirow[t]{2}{*}{ Modified Z-Score } & $-.916^{* * *}$ & $-.886^{* * *}$ & $-.906^{* * *}$ & $-.430^{* * *}$ & $-.427^{* * *}$ & $-.434^{* * *}$ \\
\hline & $(.053)$ & $(.052)$ & $(.053)$ & $(.033)$ & $(.032)$ & $(.032)$ \\
\hline \multirow[t]{2}{*}{ Return on Assets } & $-6.022^{* * *}$ & $-6.340^{* * *}$ & $-6.175^{* * *}$ & $-9.382^{* * *}$ & $-9.580^{* * *}$ & $-9.209^{* * *}$ \\
\hline & $(.586)$ & $(.587)$ & $(.589)$ & $(.431)$ & $(.435)$ & $(.432)$ \\
\hline Firm-level Controls & Yes & Yes & Yes & Yes & Yes & Yes \\
\hline Firm Fixed Effects & Yes & Yes & Yes & Yes & Yes & Yes \\
\hline Industry-by-Year Fixed Effects & Yes & No & Yes & Yes & No & Yes \\
\hline Economic Area-by-Year Fixed Effects & No & Yes & Yes & No & Yes & Yes \\
\hline Observations & 156,243 & 156,243 & 156,243 & 156,243 & 156,243 & 156,093 \\
\hline Adjusted $R^{2}$ & .600 & .595 & .602 & .662 & .654 & .667 \\
\hline
\end{tabular}




\section{Table IA.3: Additional Robustness Tests for the Effect of Shadow Union on Financial Leverage (continued)}

Panel B repeats the tests in Panel A of Table 3 in the main text by excluding firm-level control variables; Panel $\mathrm{C}$ repeats the same exercise by using one-year lagged firm-level control variables in the specifications. In columns (1) to (3), the dependent variable is Book Leverage, while in columns (4) to (6) the dependent variable is Market Leverage. Book Leverage is the debt-to-capital ratio, defined as the total debt divided by the sum of total debt and book value of equity. The total debt is the sum of long-term debt and debt in current liabilities. Market leverage is the ratio of total debt to the sum of total debt and market value of equity. Shadow Union is an indicator variable equal to one if another firm in the same local labor market passes union election during the previous five years, and zero otherwise. We winsorize all unbounded variables at the top and bottom one percent. The details of construction of all other variables are described in the appendix. Numbers in parentheses are standard errors that are clustered by firm. ${ }^{* * *},{ }^{* *}$, and ${ }^{*}$ indicate significance at the $1 \%, 5 \%$, and $10 \%$ levels, respectively.

Panel B. Without Any Firm-Level Controls

\begin{tabular}{lcccccccc}
\hline & \multicolumn{3}{c}{ Book Leverage } & & \multicolumn{3}{c}{ Market Leverage } \\
\cline { 2 - 3 } & $(1)$ & $(2)$ & $(3)$ & & $(4)$ & $(5)$ & $(6)$ \\
\hline Shadow Union & $\begin{array}{c}1.837^{* * *} \\
(.282)\end{array}$ & $\begin{array}{c}2.264^{* * *} \\
(.322)\end{array}$ & $\begin{array}{c}2.231^{* * *} \\
(.315)\end{array}$ & & $\begin{array}{c}1.881^{* * *} \\
(.244)\end{array}$ & $\begin{array}{c}2.511^{* * *} \\
(.283)\end{array}$ & $\begin{array}{c}2.349^{* * *} \\
(.274)\end{array}$ \\
\hline Firm-level Controls & No & No & No & & No & No & No \\
Firm Fixed Effects & Yes & Yes & Yes & & Yes & Yes & Yes \\
Industry-by-Year Fixed Effects & Yes & No & Yes & & Yes & No & Yes \\
State-by-Year Fixed Effects & No & Yes & Yes & & No & Yes & Yes \\
\hline Observations & 156,250 & 156,250 & 156,250 & & 156,250 & 156,250 & 156,250 \\
Adjusted $R^{2}$ & .571 & .563 & .574 & & .627 & .610 & .630 \\
\hline
\end{tabular}

Panel C. With One-Year Lagged Controls

\begin{tabular}{lcccccccc}
\hline & \multicolumn{3}{c}{ Book Leverage } & & \multicolumn{3}{c}{ Market Leverage } \\
\cline { 2 - 3 } & $(1)$ & $(2)$ & $(3)$ & & $(4)$ & $(5)$ & $(6)$ \\
\hline Shadow Union & $.663^{* *}$ & $.821^{* *}$ & $.951^{* * *}$ & & .415 & $.656^{* *}$ & $.720^{* *}$ \\
& $(.297)$ & $(.342)$ & $(.334)$ & & $(.255)$ & $(.299)$ & $(.291)$ \\
\hline Lagged Firm-level Controls & Yes & Yes & Yes & & Yes & Yes & Yes \\
Firm Fixed Effects & Yes & Yes & Yes & & Yes & Yes & Yes \\
Industry-by-Year Fixed Effects & Yes & No & Yes & & Yes & No & Yes \\
State-by-Year Fixed Effects & No & Yes & Yes & & No & Yes & Yes \\
\hline Observations & 139,038 & 139,038 & 139,038 & & 139,038 & 139,038 & 139,038 \\
Adjusted $R^{2}$ & .606 & .600 & .609 & & .665 & .653 & .667 \\
\hline
\end{tabular}




\section{Table IA.4: Coefficients on Control Variables: Robustness Tests}

Panels A1, A2, and B report the coefficients on control variables that are omitted in Panels B1, B2, and C of Table 5 in the main text, respectively. Book Leverage is the debt-to-capital ratio, defined as the total debt divided by the sum of total debt and book value of equity. The total debt is the sum of long-term debt and debt in current liabilities. Market leverage is the ratio of total debt to the sum of total debt and market value of equity. Shadow Union ${ }^{3 Y R(7 Y R)}$ is an indicator variable equal to one if another firm in the same local labor market passes union election during the previous three (seven) years, and zero otherwise. Shadow Union is an indicator variable equal to one if another firm in the same local labor market passes union election during the previous five years, and zero otherwise. Alternative Book Leverage is defined as the total debt divided by the book value of total assets, and Alternative Market Leverage is defined as the total debt divided by the market value of assets. We winsorize all unbounded variables at the top and bottom one percent. The details of construction of all other variables are described in the appendix. Numbers in parentheses are standard errors that are clustered by firm. $* * *, * *$, and $*$ indicate significance at the $1 \%, 5 \%$, and $10 \%$ levels, respectively.

Panel A1. Using Alternative Horizons: 3 Years

\begin{tabular}{|c|c|c|c|c|c|c|}
\hline & \multicolumn{3}{|c|}{ Book Leverage } & \multicolumn{3}{|c|}{ Market Leverage } \\
\hline & $(1)$ & $(2)$ & $(3)$ & $(4)$ & $(5)$ & (6) \\
\hline Shadow Union ${ }^{3 Y R}$ & $\begin{array}{c}.674^{* * *} \\
(.204)\end{array}$ & $\begin{array}{c}.867^{* * *} \\
(.236)\end{array}$ & $\begin{array}{c}.896^{* * *} \\
(.233)\end{array}$ & $\begin{array}{c}.639^{* * *} \\
(.178)\end{array}$ & $\begin{array}{c}.807^{* * *} \\
(.207)\end{array}$ & $\begin{array}{c}.835^{* * *} \\
(.203)\end{array}$ \\
\hline Tangibility & $\begin{array}{c}23.225^{* * *} \\
\quad(1.048)\end{array}$ & $\begin{array}{c}23.764^{* * *} \\
(1.052)\end{array}$ & $\begin{array}{c}23.294^{* * *} \\
(1.040)\end{array}$ & $\begin{array}{c}19.206^{* * *} \\
(.880)\end{array}$ & $\begin{array}{c}20.768^{* * *} \\
(.894)\end{array}$ & $\begin{array}{c}19.217^{\text {*** }} \\
(.875)\end{array}$ \\
\hline Market-to-Book & $\begin{array}{c}-.705^{* * *} \\
(.045)\end{array}$ & $\begin{array}{c}-.744^{* * *} \\
(.045)\end{array}$ & $\begin{array}{c}-.715^{* * *} \\
(.045)\end{array}$ & $\begin{array}{c}-1.645^{* * *} \\
(.046)\end{array}$ & $\begin{array}{c}-1.717^{* * *} \\
(.047)\end{array}$ & $\begin{array}{c}-1.642^{* * *} \\
(.046)\end{array}$ \\
\hline $\ln ($ Sales $)$ & $\begin{array}{c}3.903^{* * *} \\
(.165)\end{array}$ & $\begin{array}{c}4.153^{* * *} \\
(.166)\end{array}$ & $\begin{array}{c}3.956^{* * *} \\
(.165)\end{array}$ & $\begin{array}{c}3.482^{* * *} \\
(.132)\end{array}$ & $\begin{array}{c}3.639^{* * *} \\
(.134)\end{array}$ & $\begin{array}{c}3.514^{* * *} \\
(.134)\end{array}$ \\
\hline Modified Z-Score & $\begin{array}{c}-1.007^{* * *} \\
(.056)\end{array}$ & $\begin{array}{c}-.984^{* * *} \\
(.056)\end{array}$ & $\begin{array}{c}-1.013^{* * *} \\
(.056)\end{array}$ & $\begin{array}{c}-.481^{* * *} \\
(.035)\end{array}$ & $\begin{array}{c}-.472^{* * *} \\
(.035)\end{array}$ & $\begin{array}{c}-.487^{* * *} \\
(.035)\end{array}$ \\
\hline Return on Assets & $\begin{array}{c}-5.839^{* * *} \\
(.604)\end{array}$ & $\begin{array}{c}-6.009^{* * *} \\
(.598)\end{array}$ & $\begin{array}{c}-5.834^{* * *} \\
(.603)\end{array}$ & $\begin{array}{c}-9.395^{* * *} \\
(.450)\end{array}$ & $\begin{array}{c}-9.662^{* * *} \\
(.451)\end{array}$ & $\begin{array}{c}-9.329^{* * *} \\
(.451)\end{array}$ \\
\hline Firm-level Controls & Yes & Yes & Yes & Yes & Yes & Yes \\
\hline Firm Fixed Effects & Yes & Yes & Yes & Yes & Yes & Yes \\
\hline Industry-by-Year Fixed Effects & Yes & No & Yes & Yes & No & Yes \\
\hline State-by-Year Fixed Effects & No & Yes & Yes & No & Yes & Yes \\
\hline Observations & 150,057 & 150,057 & 150,057 & 150,057 & 150,057 & 150,057 \\
\hline Adjusted $R^{2}$ & .603 & .597 & .605 & .663 & .652 & .665 \\
\hline
\end{tabular}


Table IA.4: Coefficients on Control Variables: Robustness Tests (continued) Panel A2. Using Alternative Horizons: 7 Years

\begin{tabular}{|c|c|c|c|c|c|c|}
\hline & \multicolumn{3}{|c|}{ Book Leverage } & \multicolumn{3}{|c|}{ Market Leverage } \\
\hline & (1) & $(2)$ & $(3)$ & $(4)$ & $(5)$ & $(6)$ \\
\hline Shadow Union ${ }^{7 Y R}$ & $\begin{array}{c}.851^{* * *} \\
(.315)\end{array}$ & $\begin{array}{c}1.004^{* * *} \\
(.353)\end{array}$ & $\begin{array}{c}1.104^{* * *} \\
(.346)\end{array}$ & $\begin{array}{c}1.113^{* * *} \\
(.264)\end{array}$ & $\begin{array}{c}1.437^{* * *} \\
(.300)\end{array}$ & $\begin{array}{c}1.437^{* * *} \\
(.292)\end{array}$ \\
\hline Tangibility & $\begin{array}{c}22.799^{* * *} \\
(1.045)\end{array}$ & $\begin{array}{c}23.239^{* * *} \\
(1.048)\end{array}$ & $\begin{array}{c}22.871^{* * *} \\
(1.036)\end{array}$ & $\begin{array}{c}19.016^{* * *} \\
(.870)\end{array}$ & $\begin{array}{c}20.555^{* * *} \\
(.884)\end{array}$ & $\begin{array}{c}19.017^{* * *} \\
(.864)\end{array}$ \\
\hline Market-to-Book & $\begin{array}{c}-.690^{* * *} \\
(.044)\end{array}$ & $\begin{array}{c}-.732^{* * *} \\
(.043)\end{array}$ & $\begin{array}{c}-.702^{* * *} \\
(.044)\end{array}$ & $\begin{array}{c}-1.606^{* * *} \\
(.044)\end{array}$ & $\begin{array}{c}-1.683^{* * *} \\
(.045)\end{array}$ & $\begin{array}{c}-1.602^{\text {*** }} \\
(.044)\end{array}$ \\
\hline $\ln ($ Sales $)$ & $\begin{array}{c}3.933^{* * *} \\
(.163)\end{array}$ & $\begin{array}{c}4.177^{* * *} \\
(.164)\end{array}$ & $\begin{array}{c}3.982^{* * *} \\
(.163)\end{array}$ & $\begin{array}{c}3.457^{* * *} \\
(.130)\end{array}$ & $\begin{array}{c}3.623^{* * *} \\
(.131)\end{array}$ & $\begin{array}{c}3.482^{* * *} \\
(.131)\end{array}$ \\
\hline Modified Z-Score & $\begin{array}{c}-.913^{* * *} \\
(.053)\end{array}$ & $\begin{array}{c}-.891^{* * *} \\
(.053)\end{array}$ & $\begin{array}{c}-.919^{* * *} \\
(.053)\end{array}$ & $\begin{array}{c}-.426^{* * *} \\
(.033)\end{array}$ & $\begin{array}{c}-.420^{* * *} \\
(.032)\end{array}$ & $\begin{array}{c}-.432^{* * *} \\
(.033)\end{array}$ \\
\hline Return on Assets & $\begin{array}{c}-6.031^{* * *} \\
(.586)\end{array}$ & $\begin{array}{c}-6.248^{* * *} \\
(.582)\end{array}$ & $\begin{array}{c}-6.048^{* * *} \\
(.584)\end{array}$ & $\begin{array}{c}-9.393^{* * *} \\
(.431)\end{array}$ & $\begin{array}{c}-9.731^{* * *} \\
(.434)\end{array}$ & $\begin{array}{c}-9.334^{* * *} \\
(.431)\end{array}$ \\
\hline Firm-level Controls & Yes & Yes & Yes & Yes & Yes & Yes \\
\hline Firm Fixed Effects & Yes & Yes & Yes & Yes & Yes & Yes \\
\hline Industry-by-Year Fixed Effects & Yes & No & Yes & Yes & No & Yes \\
\hline State-by-Year Fixed Effects & No & Yes & Yes & No & Yes & Yes \\
\hline Observations & 156,250 & 156,250 & 156,250 & 156,250 & 156,250 & 156,250 \\
\hline Adjusted $R^{2}$ & .600 & .594 & .602 & .662 & .651 & .664 \\
\hline
\end{tabular}




\section{Table IA.4: Coefficients on Control Variables: Robustness Tests (continued)}

Panel B. Using Alternative Measures of Financial Leverage

\begin{tabular}{|c|c|c|c|c|c|c|}
\hline & \multicolumn{3}{|c|}{ Alternative Book Leverage } & \multicolumn{3}{|c|}{ Alternative Market Leverage } \\
\hline & (1) & $(2)$ & $(3)$ & (4) & $(5)$ & (6) \\
\hline \multirow[t]{2}{*}{ Shadow Union } & $.621^{* * *}$ & $.765^{* * *}$ & $.828^{* * *}$ & $.663^{* * *}$ & $.964^{* * *}$ & $.951^{* * *}$ \\
\hline & $(.203)$ & $(.231)$ & $(.226)$ & $(.177)$ & $(.204)$ & (.199) \\
\hline \multirow[t]{2}{*}{ Tangibility } & $19.557^{* * *}$ & $20.000^{* * *}$ & $19.611^{* * *}$ & $16.521^{* * *}$ & $17.608^{* * *}$ & $16.525^{* * *}$ \\
\hline & $(.824)$ & $(.830)$ & $(.819)$ & $(.705)$ & $(.720)$ & $(.703)$ \\
\hline \multirow[t]{2}{*}{ Market-to-Book } & $-.552^{* * *}$ & $-.580^{* * *}$ & $-.559^{* * *}$ & $-1.202^{* * *}$ & $-1.255^{* * *}$ & $-1.199^{* * *}$ \\
\hline & $(.032)$ & $(.031)$ & $(.032)$ & $(.033)$ & $(.034)$ & $(.033)$ \\
\hline \multirow[t]{2}{*}{$\ln ($ Sales $)$} & $2.944^{* * *}$ & $3.076^{* * *}$ & $2.974^{* * *}$ & $2.745^{* * *}$ & $2.845^{* * *}$ & $2.761^{* * *}$ \\
\hline & $(.123)$ & $(.124)$ & $(.123)$ & $(.101)$ & $(.102)$ & $(.101)$ \\
\hline \multirow[t]{2}{*}{ Modified Z-Score } & $-.529^{* * *}$ & $-.530^{* * *}$ & $-.533^{* * *}$ & $-.332^{* * *}$ & $-.339^{* * *}$ & $-.335^{* * *}$ \\
\hline & $(.035)$ & $(.035)$ & $(.035)$ & $(.025)$ & $(.025)$ & $(.025)$ \\
\hline \multirow[t]{2}{*}{ Return on Assets } & $-3.738^{* * *}$ & $-3.708^{* * *}$ & $-3.733^{* * *}$ & $-6.004^{* * *}$ & $-6.108^{* * *}$ & $-5.955^{* * *}$ \\
\hline & $(.406)$ & $(.402)$ & $(.405)$ & $(.320)$ & $(.322)$ & $(.321)$ \\
\hline Firm-level Controls & Yes & Yes & Yes & Yes & Yes & Yes \\
\hline Firm Fixed Effects & Yes & Yes & Yes & Yes & Yes & Yes \\
\hline Industry-by-Year Fixed Effects & Yes & No & Yes & Yes & No & Yes \\
\hline State-by-Year Fixed Effects & No & Yes & Yes & No & Yes & Yes \\
\hline Observations & 156,247 & 156,247 & 156,247 & 156,250 & 156,250 & 156,250 \\
\hline Adjusted $R^{2}$ & .626 & .622 & .629 & .670 & .660 & .672 \\
\hline
\end{tabular}




\section{Table IA.5: Coefficients on Control Variables: Marginal Increase in Probability of Unionization}

Panel A reports the coefficients on control variables that are omitted in columns (1) and (2) of Table 6 in the main text. Shadow Union is an indicator variable equal to one if another firm in the same local labor market passes union election during the previous five years, and zero otherwise. We define High (Low) Median Wage as an indicator variable equal to one if the time-series average of industry-level annual median wages of a firm is above-(below)median of the distribution, zero otherwise. We use industry-level annual median wage data from the Occupational Employment Statistics (OES) Survey by the Bureau of Labor Statistics. High Median Wage is absorbed by the firm fixed effects. $H_{0}$ : Shadow Union | Low Median Wage - Shadow Union $\mid$ High Median Wage $=0$ is based on a one-tailed test with p-values in square brackets. We winsorize all unbounded variables at the top and bottom one percent. The details of construction of all other variables are described in the appendix. Numbers in parentheses are standard errors that are clustered by firm. ***, **, and * indicate significance at the $1 \%, 5 \%$, and $10 \%$ levels, respectively.

Panel A. Workers in the Middle-to-Bottom of Wage Distribution

\begin{tabular}{|c|c|c|}
\hline & Book Leverage & Market Leverage \\
\hline & (1) & $(2)$ \\
\hline Shadow Union | High Median Wage & $\begin{array}{l}.293 \\
(.471)\end{array}$ & $\begin{array}{l}.615^{*} \\
(.373)\end{array}$ \\
\hline Shadow Union | Low Median Wage & $\begin{array}{c}1.545^{* * *} \\
(.456)\end{array}$ & $\begin{array}{c}1.569^{* * *} \\
(.393)\end{array}$ \\
\hline High Median Wage & (omitted) & (omitted) \\
\hline Tangibility & $\begin{array}{c}21.434^{* * *} \\
(1.202)\end{array}$ & $\begin{array}{c}17.970^{* * *} \\
\quad(.994)\end{array}$ \\
\hline Market-to-Book & $\begin{array}{c}-.654^{* * *} \\
\quad(.046)\end{array}$ & $\begin{array}{c}-1.462^{* * *} \\
(.044)\end{array}$ \\
\hline $\ln ($ Sales $)$ & $\begin{array}{c}3.790^{* * *} \\
(.178)\end{array}$ & $\begin{array}{c}3.286^{* * *} \\
\quad(.140)\end{array}$ \\
\hline Modified Z-Score & $\begin{array}{c}-.813^{* * *} \\
(.051)\end{array}$ & $\begin{array}{c}-.367^{* * *} \\
(.032)\end{array}$ \\
\hline Return on Assets & $\begin{array}{c}-5.065^{* * *} \\
(.618)\end{array}$ & $\begin{array}{c}-8.072^{* * *} \\
(.450)\end{array}$ \\
\hline$H_{0}:$ Shadow Union | Low Median Wage & $1.252^{* *}$ & $0.954^{* *}$ \\
\hline -Shadow Union $\mid$ High Median Wage $=0$ & {$[0.022]$} & {$[0.030]$} \\
\hline Firm-level Controls & Yes & Yes \\
\hline Firm Fixed Effects & Yes & Yes \\
\hline Industry-by-Year Fixed Effects & Yes & Yes \\
\hline State-by-Year Fixed Effects & Yes & Yes \\
\hline Observations & 122,216 & 122,216 \\
\hline Adjusted $R^{2}$ & .584 & .643 \\
\hline
\end{tabular}




\section{Table IA.5: Coefficients on Control Variables: Marginal Increase in Probability of Unionization (continued)}

Panel B reports the coefficients on control variables that are omitted in columns (3) and (4) of Table 6 in the main text. Shadow Union is an indicator variable equal to one if another firm in the same local labor market passes union election during the previous five years, and zero otherwise. We define Shadow Union ${ }^{\text {Multi (Single) }}$ as an indicator variable equal to one if other firms in the same local labor market pass multiple (single) union elections during the previous five years, and zero otherwise. $H_{0}$ : Shadow Union ${ }^{\text {Multi }}-$ Shadow Union ${ }^{\text {Single }}=0$ is based on a one-tailed test with p-values in square brackets. We winsorize all unbounded variables at the top and bottom one percent. The details of construction of all other variables are described in the appendix. Numbers in parentheses are standard errors that are clustered by firm. ${ }^{* *},{ }^{* *}$, and ${ }^{*}$ indicate significance at the $1 \%, 5 \%$, and $10 \%$ levels, respectively.

Panel B. Salience of Union Victory: Multiple vs. Single Shadow Union Organizing

\section{Book Leverage}

Shadow Union $^{\text {Multi }}$
Shadow Union ${ }^{\text {Single }}$
Tangibility
Market-to-Book
$\ln$ (Sales)

Modified Z-Score

Return on Assets

\section{$1.312^{* * *}$}

$22.919 * * *$

$-.705^{* * *}$

$4.000^{* * *}$

$-.923^{* * *}$

$-6.033^{* * *}$
$H_{0}:$ Shadow Union $^{\text {Multi }}-$ Shadow Union Single $^{2}=0$

Firm-level Controls

Firm Fixed Effects

Industry-by-Year Fixed Effects

State-by-Year Fixed Effects

Observations

Adjusted $R^{2}$
(1)

$.833^{* *}$

(1.036)

(.044)

(.163)

(.053)

(.584)

$0.479^{*}$

[0.068]

Market Leverage

.475

$19.077^{* * *}$

$-1.607^{* * *}$

$3.506^{* * *}$

$-.437^{* * *}$

$-9.318^{* * *}$

(.432)

$0.474^{* *}$

[0.048]

Yes

Yes

Yes

Yes

156,250

156,250

.664 


\section{Table IA.6: Coefficients on Control Variables: Union Rents}

This table reports the coefficients on control variables that are omitted in Table 7 in the main text. The coefficient comparisons at the bottom of the table are based on one-tailed tests with p-values in square brackets. We winsorize all unbounded variables at the top and bottom one percent. The details of construction of all variables are described in the appendix. Numbers in parentheses are standard errors that are clustered by firm. ***, **, and $*$ indicate significance at the $1 \%, 5 \%$, and $10 \%$ levels, respectively.

\begin{tabular}{|c|c|c|c|c|c|c|}
\hline & \multicolumn{2}{|c|}{$\begin{array}{c}\text { Labor } \\
\text { Intensity }\end{array}$} & \multicolumn{2}{|c|}{$\begin{array}{c}\text { Unemployment } \\
\text { Rates }\end{array}$} & \multicolumn{2}{|c|}{$\begin{array}{c}\text { Product Market } \\
\text { Competition }\end{array}$} \\
\hline & $\begin{array}{c}\text { Book } \\
\text { Leverage }\end{array}$ & $\begin{array}{l}\text { Market } \\
\text { Leverage }\end{array}$ & $\begin{array}{c}\text { Book } \\
\text { Leverage }\end{array}$ & $\begin{array}{c}\text { Market } \\
\text { Leverage }\end{array}$ & $\begin{array}{c}\text { Book } \\
\text { Leverage }\end{array}$ & $\begin{array}{l}\text { Market } \\
\text { Leverage }\end{array}$ \\
\hline & (1) & $(2)$ & $(3)$ & (4) & $(5)$ & $(6)$ \\
\hline Shadow Union | High Union Rents & $\begin{array}{c}1.832^{* * *} \\
(.448)\end{array}$ & $\begin{array}{c}1.453^{* * *} \\
(.371)\end{array}$ & $\begin{array}{c}1.506^{* * *} \\
(.365)\end{array}$ & $\begin{array}{c}1.380^{* * *} \\
(.322)\end{array}$ & $\begin{array}{c}2.991^{* * *} \\
(.777)\end{array}$ & $\begin{array}{c}1.718^{* * *} \\
(.663)\end{array}$ \\
\hline Shadow Union | Low Union Rents & $\begin{array}{l}.702^{*} \\
(.387)\end{array}$ & $\begin{array}{c}1.035^{* * *} \\
(.342)\end{array}$ & $\begin{array}{l}.604 \\
(.441)\end{array}$ & $\begin{array}{l}.720^{*} \\
(.377)\end{array}$ & $\begin{array}{l}.600 \\
(.656)\end{array}$ & $\begin{array}{l}.757 \\
(.575)\end{array}$ \\
\hline High Union Rents & $\begin{array}{c}-1.569^{* * *} \\
(.551)\end{array}$ & $\begin{array}{l}-.576 \\
(.463)\end{array}$ & (omitted) & (omitted) & $\begin{array}{c}1.805^{* *} \\
(.771)\end{array}$ & $\begin{array}{l}.887 \\
(.647)\end{array}$ \\
\hline Tangibility & $\begin{array}{c}21.966^{* * *} \\
(1.113)\end{array}$ & $\begin{array}{c}19.036^{* * *} \\
(.937)\end{array}$ & $\begin{array}{c}22.050^{* * *} \\
(1.096)\end{array}$ & $\begin{array}{c}19.358^{* * *} \\
(.933)\end{array}$ & $\begin{array}{c}24.888^{* * *} \\
(2.087)\end{array}$ & $\begin{array}{c}19.303^{* * *} \\
(1.779)\end{array}$ \\
\hline Market-to-Book & $\begin{array}{c}-.832^{* * *} \\
(.053)\end{array}$ & $\begin{array}{c}-1.852^{* * *} \\
(.056)\end{array}$ & $\begin{array}{c}-.841^{* * *} \\
(.053)\end{array}$ & $\begin{array}{c}-1.905^{* * *} \\
(.057)\end{array}$ & $\begin{array}{c}-.885^{* * *} \\
(.073)\end{array}$ & $\begin{array}{c}-1.617^{* * *} \\
(.072)\end{array}$ \\
\hline $\ln ($ Sales $)$ & $\begin{array}{c}4.095^{* * *} \\
(.177)\end{array}$ & $\begin{array}{c}3.569^{* * *} \\
(.143)\end{array}$ & $\begin{array}{c}4.100^{* * *} \\
(.174)\end{array}$ & $\begin{array}{c}3.594^{* * *} \\
(.141)\end{array}$ & $\begin{array}{c}3.972^{* * *} \\
(.285)\end{array}$ & $\begin{array}{c}3.056^{* * *} \\
(.219)\end{array}$ \\
\hline Modified Z-Score & $\begin{array}{c}-.956^{* * *} \\
(.060)\end{array}$ & $\begin{array}{c}-.494^{* * *} \\
(.039)\end{array}$ & $\begin{array}{c}-.990^{* * *} \\
(.061)\end{array}$ & $\begin{array}{c}-.509^{* * *} \\
(.040)\end{array}$ & $\begin{array}{c}-.826^{* * *} \\
(.089)\end{array}$ & $\begin{array}{c}-.327^{* * *} \\
(.054)\end{array}$ \\
\hline Return on Assets & $\begin{array}{c}-7.790^{* * *} \\
(.648)\end{array}$ & $\begin{array}{c}-10.576^{* * *} \\
(.491)\end{array}$ & $\begin{array}{c}-8.033^{* * *} \\
(.651)\end{array}$ & $\begin{array}{c}-11.213^{* * *} \\
(.499)\end{array}$ & $\begin{array}{c}-8.415^{* * *} \\
(1.013)\end{array}$ & $\begin{array}{c}-10.542^{* * *} \\
(.748)\end{array}$ \\
\hline $\begin{array}{l}H_{0}: \text { Shadow Union } \mid \text { High Rents } \\
\quad-\text { Shadow Union } \mid \text { Low Rents }=0\end{array}$ & $\begin{array}{l}1.130^{* *} \\
{[0.014]}\end{array}$ & $\begin{array}{c}0.418 \\
{[0.167]}\end{array}$ & $\begin{array}{c}0.902^{* *} \\
{[0.030]}\end{array}$ & $\begin{array}{l}0.660^{*} \\
{[0.058]}\end{array}$ & $\begin{array}{c}2.391^{* * *} \\
{[0.001]}\end{array}$ & $\begin{array}{l}0.961^{*} \\
{[0.075]}\end{array}$ \\
\hline Firm-level Controls & Yes & Yes & Yes & Yes & Yes & Yes \\
\hline Firm Fixed Effects & Yes & Yes & Yes & Yes & Yes & Yes \\
\hline Industry-by-Year Fixed Effects & Yes & Yes & Yes & Yes & Yes & Yes \\
\hline State-by-Year Fixed Effects & Yes & Yes & Yes & Yes & Yes & Yes \\
\hline Observations & 140,536 & 147,187 & 140,536 & 147,187 & 48,886 & 48,886 \\
\hline Adjusted $R^{2}$ & .616 & .614 & .676 & .672 & .611 & .676 \\
\hline
\end{tabular}

